\title{
Energy End-Use Metering in Two Modular Office Buildings at Fort Irwin, California
}

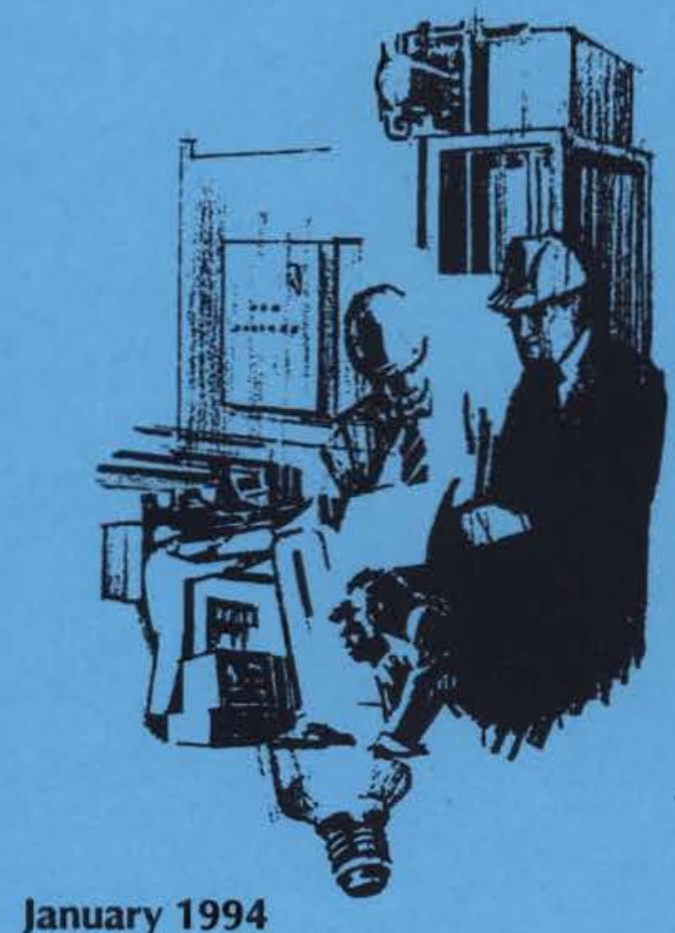

Prepared for the U.S. Department of Energy Federal Energy Management Program under Contract DE-AC06-76RLO 1830

Pacific Northwest Laboratory Operated for the U.S. Department of Energy by Battelle Memorial Institute 


\title{
DISCLAIMER
}

This report was prepared as an account of work sponsored by an agency of the United States Government. Neither the United States Government nor any agency thereof, nor Battelle Memorial Institute, nor any of their employees, makes any warranty, expressed or implied, or assumes any legal liability or responsibility for the accuracy, completeness, or usefulness of any information, apparatus, product, or process disclosed, or represents that its use would not infringe privately owned rights. Reference herein to any specific commercial product, process, or service by trade name, trademark, manufacturer, or otherwise does not necessarily constitute or imply its endorsement, recommendation, or favoring by the United States Government or any agency thereof, or Battelle Memorial Institute. The views and opinions of authors expressed herein do not necessarily state or reflect those of the United States Government or any agency thereof.

\author{
PACIFIC NORTHWEST LABORATORY \\ operated by \\ BATTELLE MEMORIAL INSTITUTE \\ for the \\ UNITED STATES DEPARTMENT OF ENERGY \\ under Contract DE-ACO6-76RLO 1830
}

Printed in the United States of America

Available to DOE and DOE contractors from the

Office of Scientific and Technical Information, P.O. Box 62, Oak Ridge, TN 37831; prices available from (615) 576-8401. FTS 626-8401.

Available to the public from the National Technical Information Service, U.S. Department of Commerce, 5285 Port Royal Rd., Springfield, VA 22161. 
PNL-8952

UC-350

\title{
Energy End-Use Metering in Two Modular Office Buildings at Fort Irwin, California
}

\author{
P. R. Armstrong \\ J. M. Keller
}

January 1994

Prepared for

the U.S. Department of Energy

Federal Energy Management Program

under Contract DE-AC06-76RLO 1830

Pacific Northwest Laboratory

Richland, Washington 99352 



\section{Preface}

The goal of the U.S. Department of Energy (DOE) Federal Energy Management Program (FEMP) is to facilitate energy-efficiency improvements at federal facilities. This is accomplished by a balanced program of technology development, facility assessment, and use of cost-sharing procurement mechanisms. Technology development focuses on the tools, software, and procedures used to identify and evaluate efficiency technologies and improvements. For facility assessment, FEMP provides metering equipment and trained analysts to federal agencies exhibiting a commitment to improve energy-use efficiency. To assist in procurement of energy-efficiency measures, FEMP helps federal agencies devise and implement performance contracting and utility demand-side management strategies.

Pacific Northwest Laboratory (PNL) $)^{(a)}$ supports the FEMP mission. The Laboratory and its contractors work with federal facility energy managers to assess and implement energy-efficiency improvements at federal facilities nationwide.

The capabilities of the Mobile Energy Laboratory (MEL) provide onsite measurement and evaluation of energy conversion, distribution, and end-use efficiency at federal facilities. The results may be used to justify changes in operating procedures, maintenance efforts, system designs, or energy-using equipment. The MEL capabilities can subsequently be used to assess the results of energy-efficiency projects.

(a) Pacific Northwest Laboratory is operated for the U.S. Department of Energy by Battelle Memorial Institute under Contract DE-AC06-76RLO 1830. 



\section{Executive Summary}

This report documents the application of the Mobile Energy Laboratory (MEL) at Fort Irwin for the period 21 December 1989 to 27 January 1992. The MEL capabilities are maintained and applied by Pacific Northwest Laboratory (PNL) for the U.S. Department of Energy (DOE) Federal Energy Management Program (FEMP). The U.S. Army Forces Command (FORSCOM) has contracted with DOE to apply MEL energy-efficiency tests at FORSCOM installations.

\section{Scope and Purpose}

This test was conducted under the Mobile Energy Laboratory (MEL) Assignment Plan (MAP) IRWIN002, attached as Appendix A. The purpose of the test was to monitor electrical demands in Buildings 567 and 571 by end use and to monitor the response of the HVAC systems to internal and external loads.

\section{Results}

Results of two years of monitoring are summarized below. The observed energy-use intensities (EUIs) were $13.7 \mathrm{kWh} / \mathrm{ft}^{2}$-yr for Building 567 and $10.4 \mathrm{kWh} / \mathrm{ft}^{2}$-yr for Building 571 . The corresponding numbers for HVAC energy were 5.9 and $5.3 \mathrm{kWh} / \mathrm{ft}^{2}$-yr. Lighting used about $35 \%$, primary HVAC $40 \%$ (heating $8 \%$, cooling $32 \%$ ), supply fans $3 \%$ and other equipment (mostly plug loads) about $20 \%$ of the total. Over $10 \%$ of the primary HVAC energy used in Building 567 was the result of simultaneous heating and cooling. Six energy conservation measures were evaluated: 1) delamping and retrofit of T-12 fluorescent fixtures with T-8 systems; 2 ) installation of two-speed fans with operation at the lower speed $(67 \%$ of rated airflow) during occupied periods whenever a unit is not heating or cooling; 3) retrofit of heat pump compressors with two-speed compressors; 4) installation of controls that eliminate non-productive simultaneous heating and cooling and provide improved night and weekend setback; 5) coating the existing black roof material with a white reflective material; and 6) adding an economizer system to provide outside air cooling. The estimated energy savings as a percent of whole-building energy use are:

- Lighting HVAC Savings - 26\%

- Two-Speed Fans - 2\%

- Two-Speed Compressors - $11 \%$

- Improved HVAC Controls - 5\%

- White Roof Coating - 5\%

- Economizer Cooling - 5\%

The total energy savings that can be achieved through the measures is $49 \%$. 


\section{Recommendations}

Based on these findings and other information presented in the report, the following recommendations are made:

- Weekend setback controls should be installed;

- A heating/cooling arbitration control circuit should be installed to prevent simultaneous heating and cooling;

- Two-speed fans and associated controls should be installed;

- Optimal-start controls should be installed;

- Existing black roofing should be coated with reflective materials;

- Economizer cooling equipment and controls should be installed;

- New modular buildings should include the foregoing features;

- New modular buildings should be designed with central heat pumps that use variable-speed or twospeed compressors. This will simplify setback and economizer control, eliminate simultaneous heating and cooling, and increase distribution fan and heat pump seasonal efficiencies.

\section{Energy Use Impact}

The total estimated savings that can be achieved by implementing the recommended efficiency and conservation measures in all 47 modular office buildings at Fort Irwin is $1,346 \mathrm{MWh} / \mathrm{yr}$, or $\$ 128,000 / \mathrm{yr}$. 


\section{Contents}

Preface $\ldots \ldots \ldots \ldots \ldots \ldots \ldots \ldots \ldots \ldots \ldots \ldots \ldots \ldots \ldots \ldots$ iii

Executive Summary $\ldots \ldots \ldots \ldots \ldots \ldots \ldots \ldots \ldots \ldots \ldots \ldots \ldots \ldots$

1.0 Introduction $\ldots \ldots \ldots \ldots \ldots \ldots \ldots \ldots \ldots \ldots \ldots \ldots \ldots \ldots \ldots \ldots \ldots$

2.0 Facility Description $\ldots \ldots \ldots \ldots \ldots \ldots \ldots \ldots \ldots \ldots \ldots \ldots \ldots \ldots \ldots \ldots$

3.0 Test Procedures and Equipment $\ldots \ldots \ldots \ldots \ldots \ldots \ldots \ldots \ldots \ldots \ldots \ldots \ldots$

4.0 Observations and Analysis $\ldots \ldots \ldots \ldots \ldots \ldots \ldots \ldots \ldots \ldots \ldots \ldots \ldots \ldots \ldots$

4.1 Short-Term Observations $\ldots \ldots \ldots \ldots \ldots \ldots \ldots \ldots \ldots \ldots \ldots \ldots \ldots$

4.2 Long-Term Observations $\ldots \ldots \ldots \ldots \ldots \ldots \ldots \ldots \ldots \ldots \ldots$

4.3 Average Daily Demand Profiles $\ldots \ldots \ldots \ldots \ldots \ldots \ldots \ldots \ldots \ldots \ldots$

5.0 Energy Resource Opportunities $\ldots \ldots \ldots \ldots \ldots \ldots \ldots \ldots \ldots \ldots \ldots \ldots \ldots \ldots$

5.1 Improved HVAC Controls $\ldots \ldots \ldots \ldots \ldots \ldots \ldots \ldots \ldots \ldots \ldots \ldots \ldots \ldots$

5.2 Two-Speed Fan Motors $\ldots \ldots \ldots \ldots \ldots \ldots \ldots \ldots \ldots \ldots \ldots \ldots \ldots \ldots$

5.3 Two-Speed Compressors $\ldots \ldots \ldots \ldots \ldots \ldots \ldots \ldots \ldots \ldots \ldots \ldots \ldots$

5.4 Lighting Retrofit $\ldots \ldots \ldots \ldots \ldots \ldots \ldots \ldots \ldots \ldots \ldots \ldots \ldots \ldots$

5.5 White Roof Coating $\ldots \ldots \ldots \ldots \ldots \ldots \ldots \ldots \ldots \ldots \ldots \ldots \ldots$

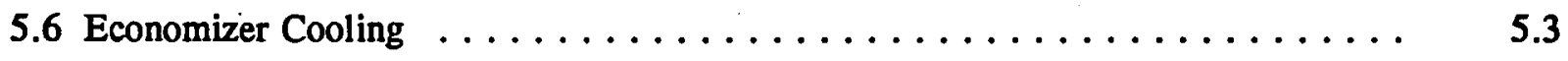

5.7 Summary of EROs $\ldots \ldots \ldots \ldots \ldots \ldots \ldots \ldots \ldots \ldots \ldots \ldots$

6.0 Conclusions and Recommendations $\ldots \ldots \ldots \ldots \ldots \ldots \ldots \ldots \ldots \ldots \ldots \ldots \ldots$

6.1 Existing Buildings $\ldots \ldots \ldots \ldots \ldots \ldots \ldots \ldots \ldots \ldots \ldots \ldots \ldots \ldots$

6.2 New Buildings $\ldots \ldots \ldots \ldots \ldots \ldots \ldots \ldots \ldots \ldots \ldots \ldots \ldots \ldots \ldots \ldots$

7.0 References $\ldots \ldots \ldots \ldots \ldots \ldots \ldots \ldots \ldots \ldots \ldots \ldots \ldots \ldots \ldots \ldots \ldots \ldots$

Appendix A - MEL Assignment Plan $\ldots \ldots \ldots \ldots \ldots \ldots \ldots \ldots \ldots \ldots \ldots \ldots$

Appendix B - Glossary $\ldots \ldots \ldots \ldots \ldots \ldots \ldots \ldots \ldots \ldots \ldots \ldots \ldots \ldots \ldots \ldots$ 


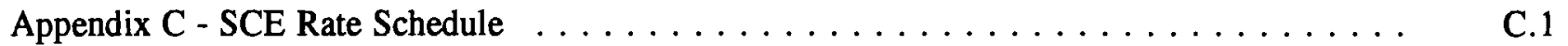

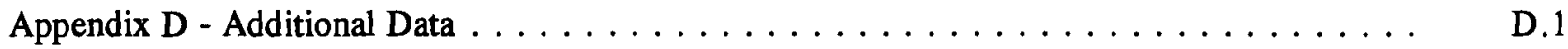




\section{Figures}

4.1 Non-HVAC Loads in Building 567 for the week of 22 January $1990 \ldots \ldots .2$

4.2 Primary Heating and Cooling Power in Building 567 for the

Week of 22 January $1990 \ldots \ldots \ldots \ldots \ldots \ldots \ldots$

4.3 Primary Heating and Cooling Power in Building 567 for the Week

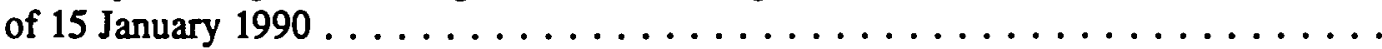

4.4 Frequency of 15-Minute Average Heat Pump Power in

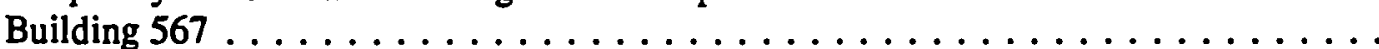

4.5 Frequency of 15-Minute Average Power for all Heat Pumps

Together in Building 567

4.6 Indoor Air Temperature Histories in Modules 1, 2, 5, 6 and

of Building 567 for the Week of 22 January 1990

4.7 Outdoor Temperature and Average Indoor Air Temperatures in

Buildings 567 and 571 for the Week of 22 January 1990

4.8 Workday Average Primary HVAC Loads in Building $567 \ldots \ldots \ldots \ldots \ldots$

4.9 Workday Average Primary HVAC Loads in Building $571 \ldots \ldots \ldots \ldots$

4.10 Non-Workday Average Primary HVAC Loads in Building $567 \ldots \ldots \ldots$

4.11 Non-Workday Average Primary HVAC Loads in Building $571 \ldots \ldots \ldots$

4.12 History of Workday Average Non-HVAC Loads in Building $567 \ldots \ldots \ldots \ldots$

4.13 History of Workday Average Non-HVAC Loads in Building $571 \ldots \ldots$. . . . . . . . 4.9

4.14 Non-Workday Average Non-HVAC Loads in Building $567 \ldots \ldots \ldots \ldots$

4.15 Non-Workday Average Non-HVAC Loads in Building $571 \ldots \ldots \ldots$

4.16 Daily Average Demand Profile in Building 567 for Pure

Lighting Circuits During Four Distinct Monitoring Periods . . . . . . . . . . . 4.12

4.17 Daily Average Demand Profile in Building 571 for Pure

Lighting Circuits During Four Distinct Monitoring Periods . . . . . . . . . . 4.12

4.18 Average Weekday Demand Profiles for the Entire Monitoring Period . . . . . . . . 4.13 
4.19 Average Non-Weekday Demand Profiles for the Entire

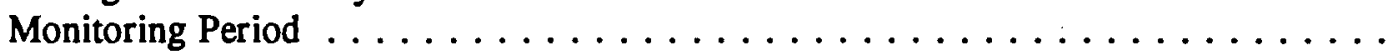

4.20 Weekday and Weekend Non-HVAC Demand Profiles for

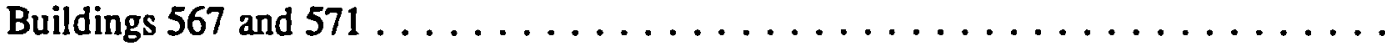




\section{Tables}

3.1 CT Channel Assignments for End-Use Metering Test $\ldots \ldots \ldots \ldots \ldots \ldots$

4.1 Energy Use in Building 567 By End Use $\ldots \ldots \ldots \ldots \ldots \ldots \ldots \ldots$

$4.2 \quad$ Energy Use in Building 571 By End Use $\ldots \ldots \ldots \ldots \ldots \ldots \ldots \ldots$

5.1 Present Value of Alternative Projects Shown in Ascending Order of

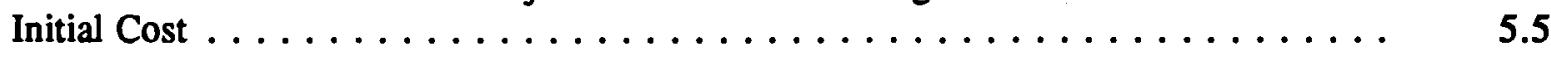





\subsection{Introduction}

Equipment from the Mobile Energy Laboratory (MEL) testing and application program supported by FEMP was applied to measure end-use loads in two modular office buildings at Fort Irwin, a U.S. Army Forces Command training facility near Barstow, California. Buildings 567 and 571 were selected as representative of the many modular office buildings in use at the site. The MEL equipment was operated throughout 1990 and 1991. MEL Test Procedure \#5, Electrical End-Use Metering (Armstrong et al. 1993a) was followed in the installation and operation of the monitoring equipment.

The test involved monitoring electric loads and HVAC responses to internal and external loads and thermal conditions affecting Buildings 567 and 571 . The monitoring objectives were to 1) provide information for recommending cost-effective energy efficiency measures and 2) provide a baseline for assessing energy savings resulting from any energy efficiency measures that are implemented in the monitored and similar buildings.

Results of the monitoring project are presented in the body of this report. Section 2 provides a brief description of the monitored facilities. Section 3 describes the monitoring hardware and application. Section 4 presents and interprets the monitored data. Section 5 evaluates six applicable energy resource opportunities. Section 6 provides the recommendations and conclusions of the study, and Section 7 contains the references.

The MEL Assignment Plan, MAP IRWIN-002, is attached as Appendix A. Appendix B is a glossary of terms, acronyms, and units of measure. Appendix C contains relevant portions of Southern California Edison Company's rate schedule used in the evaluation of energy resource opportunities. Appendix D contains a series of weekly end-use power demand and temperature histories, average day profiles and demand frequency distributions to give the interested reader deeper insight into how the modular buildings at Fort Irwin use energy. 



\subsection{Facility Description}

Building 567 consists of eight 12 - by 60 - $\mathrm{ft}$ modules with an aggregate floor area of $5760 \mathrm{ft}^{2}$. The building contains offices, a conference room, and a break room and is occupied primarily by military personnel assigned to the Directorate of Logistics. Building 571 consists of seven $12-$ by 60 - $\mathrm{ft}$ modules with an aggregate floor area of $5040 \mathrm{ft}^{2}$. This building contains offices and a break room and is occupied primarily by civilian personnel assigned to Finance. The two southeast-most modules of Building 571 were practically unoccupied when monitoring commenced.

At the outset of the end-use monitoring test Fort Irwin had 30 modular office/administrative buildings similar to Buildings 567 and 571 and 17 more such buildings were added in 1990. The aggregate floor area of these buildings is $223,920 \mathrm{ft}^{2}$. Modular buildings at Fort Irwin generally consist of four to eight modules connected side-by-side. The average floor area is equivalent to 6.6 modules per building. Construction, lighting type, and HVAC type are very similar across buildings. However, there are some differences among the modular buildings' furnishings and lighting layouts. Electrical energy use at Fort Irwin is thought to be particularly inefficient in modular buildings like Buildings 567 and 571. 



\subsection{Test Procedures and Equipment}

The light and plug circuits of each building were divided into three groups of pure lighting loads, pure plug loads and mixed (light, plug, and small water heater) loads. The power drawn by each heat pump was monitored separately. Room temperatures were monitored at five locations in Building 567 and at four locations in Building 571. Outdoor temperature and solar radiation were monitored at Building 571. All eight supply air temperatures were monitored in Building 567 in order to distinguish between each heat pump's heating and cooling modes of operation.

A PNL 56-channel field data acquisition system (FDAS) and over 70 current transformers (CTs) were installed in each building. The CTs are wired in series for each similar group of loads and the leads from each series loop, which carry a voltage proportional to current for the whole group, connect to FDAS CT input terminals.

There is one two-phase (120/208 volt) electrical distribution panel per module. Thus, Building 567 has eight panels and Building 571 has seven panels. Each panel has four types of loads: lights, plugs, mixed lights and plugs, and a heat pump. Four pairs of CTs were installed in each panel with each pair corresponding to one of the four load types and the CTs of each pair corresponding to the two power phases. A fifth pair of CTs was installed in each panel to measure the total current into the panel. The CTs for a given load type and phase were connected in series across all panels except in the case of the heat pumps, which were monitored individually. The CT channels for the two loggers are enumerated in Table 3.1.

Table 3.1. CT Channel Assignments for End-use Metering Test

\begin{tabular}{|l|c|l||}
\hline \multicolumn{1}{|c|}{ Building 567 } & Building 571 & \\
\hline Main A, B & Main A, B & (sum across all panels) \\
\hline Lights A, B & Lights A, B & (sum across all panels) \\
\hline Plugs A, B & Plugs A, B & (sum across all panels) \\
\hline Mixed A, B & Mixed A, B & (sum across all panels) \\
\hline HP1 A, B & HP1 A, B & \\
\hline HP2 A, B & HP2 A, B & \\
\hline HP3 A, B & HP3 A, B & \\
\hline HP4 A, B & HP4 A, B & \\
\hline HP5 A, B & HP5 A, B & \\
\hline HP6 A, B & HP6 A, B & \\
\hline HP7 A,B & HP7 A,B & \\
\hline HP8 A,B & & \\
\hline
\end{tabular}


Thermistors were installed to sense room and supply air temperatures. A linearized YSI thermistor senses outdoor temperature and a LiCor silicon cell pyranometer senses solar radiation on a horizontal surface.

The instruments were installed in late December 1989, and monitoring officially commenced January 1 , 1990. The buildings were monitored for two years except for a few periods when data were lost for a week or two due to phone line or modem problems. The analysis presented here covers only periods when both loggers were operating. 


\subsection{Observations and Analysis}

Building 567 was instrumented with supply air temperature sensors that made it possible to distinguish between the heating and cooling modes of each heat pump. Long-term HVAC and non-HVAC loads and average-day profiles are reported for both Buildings 567 and 571.

\subsection{Short-Term Observations}

A typical winter week (22-28 January) in the power demand history of Building 567 is shown in Figures 4.1 through 4.7. Figure 4.1 shows the non-HVAC loads. The lighting loads are very predictable and regular. The plug and mixed loads vary more but are still fairly predictable. Weekend loads and nighttime loads are very low and constant.

The aggregate electric loads for heat pumps operating in cooling mode and the aggregate electric loads for heat pumps operating in heating mode are shown in Figure 4.2. Heating power demand is greatest in the morning during recovery from night setback. Heating usually stops when occupants arrive and turn lights and equipment on at 0800 because the internal gains are usually sufficient to maintain the heating setpoint. Cooling usually commences at about noon and continues until occupants depart at 1700 . This pattern is apparent even in cold weather, such as occurred during the week of January 15-21, 1990. Heat pumps operated throughout the nights of 17 and 18 January but cooling was still called for on the afternoons of January 18 and 19, as shown in Figure 4.3.

There are times (e.g., the morning of 26 January) when heating and cooling occur simultaneously. Most of this simultaneous heating and cooling is due to thermostat or operator error (e.g., a heating setpoint in one module that is higher than the cooling setpoint in an adjacent module). This condition is wasteful and should be eliminated.

Heating and cooling demand distributions are shown in Figures 4.4 and 4.5 to help assess part load operation of the heat pumps.

Figure 4.4 shows the distribution of average 15-minute demands for the heat pumps in Building 567. Both heating and cooling distributions have a peak at about $4 \mathrm{~kW}$, corresponding to the nominal, full-capacity load of one heat pump unit. Note that cooling actually has two peaks, indicating variation in capacity which may be due to different refrigerant charges in different units or to the normal variations in operating conditions. The points that fall between zero and full nominal capacity result whenever a unit cycles on or off during the 15-minute demand averaging interval. The areas under the fractional-capacity parts of the curves are typically greater than the areas under the full-capacity peaks, indicating that most of the heating and cooling effect is delivered in cycles of less than 15-minutes duration. Note that the heating distributions are consistent with reports that strip heaters (i.e., in-duct electric resistance heaters) have been disabled in most or all of the modular buildings at Fort Irwin. A typical 3-ton heat pump would be equipped with 5- to 10-kW strip heaters but no such mode appears in the frequency distribution curve.

Figure 4.5 shows the distribution of demand obtained by taking the average of 15 -minute demands over all eight heat pump units in Building 567. Note discrete peaks corresponding to 1, 2, 3 or 4 units operating 
simultaneously in cooling mode. The heating demand distribution shows a similar behavior with up to six or seven units operating simultaneously. The simultaneous heating mode operation of several units occurs regularly during morning recovery from night setback.

Indoor air temperature histories for the week are shown in Figure 4.6. A sharp temperature rise is evident each morning. Internal gains cause temperatures to continue to rise after heating demand is satisfied until the cooling setpoint is reached. The behavior in Figure 4.6 indicates heating setpoints of around $24^{\circ} \mathrm{C}$ and cooling setpoints of around $26^{\circ} \mathrm{C}$. Note that the heat pumps operated all day on the Saturday, 27 January, and Sunday, 28 January, indicating that there was no weekend setback strategy in effect. Thermostat "droop" is also evident: daytime indoor air temperatures are about $23^{\circ} \mathrm{C}$ instead of $24^{\circ} \mathrm{C}$.

Figure 4.7 shows histories of the average of the five indoor temperatures measured in Building 567, the average of the four indoor temperatures measured in Building 571, and the outdoor air temperature. Here the different thermostat types used in the two buildings is apparent. The electronic thermostats in Building 571 appear to have a smaller deadband and appear to be programmed for weekend heating setback. The apparent lower rate of temperature decay at night in Building 571 may be the result of one or more of the thermostats failing to enter night setback mode. Indeed, average weekend HVAC energy use over the entire 2-year monitoring period (see Tables 4.1 and 4.2, discussed later) indicates that weekend setback was more effective in Building 567 than in Building 571.

The lack of an aggressive night and weekend setback strategy, and the occurrence of simultaneous heating and cooling, point to a need for improved controls and improved operation and maintenance.

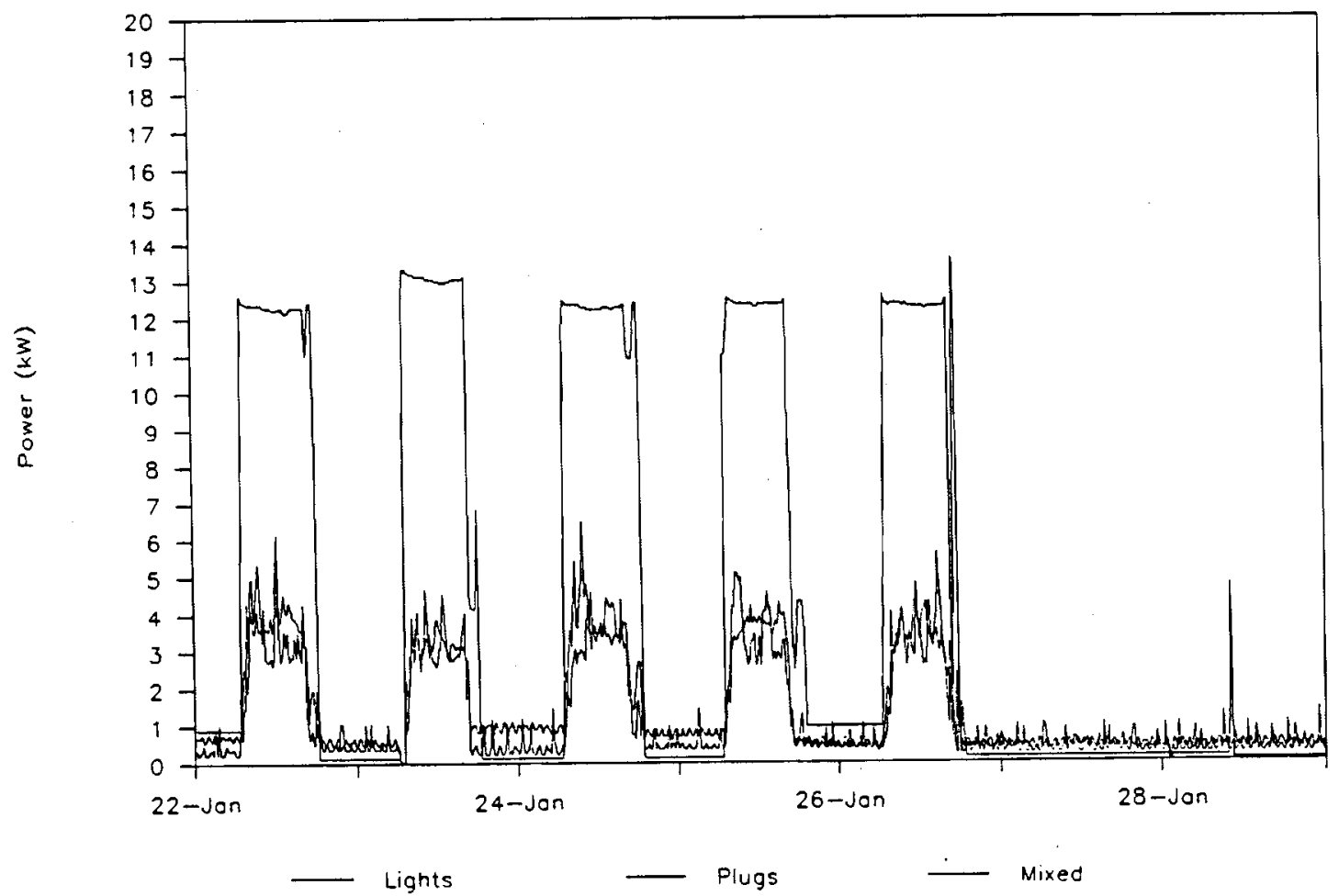

Figure 4.1. Non-HVAC Loads in Building 567 for the Week of 22 January 1990 


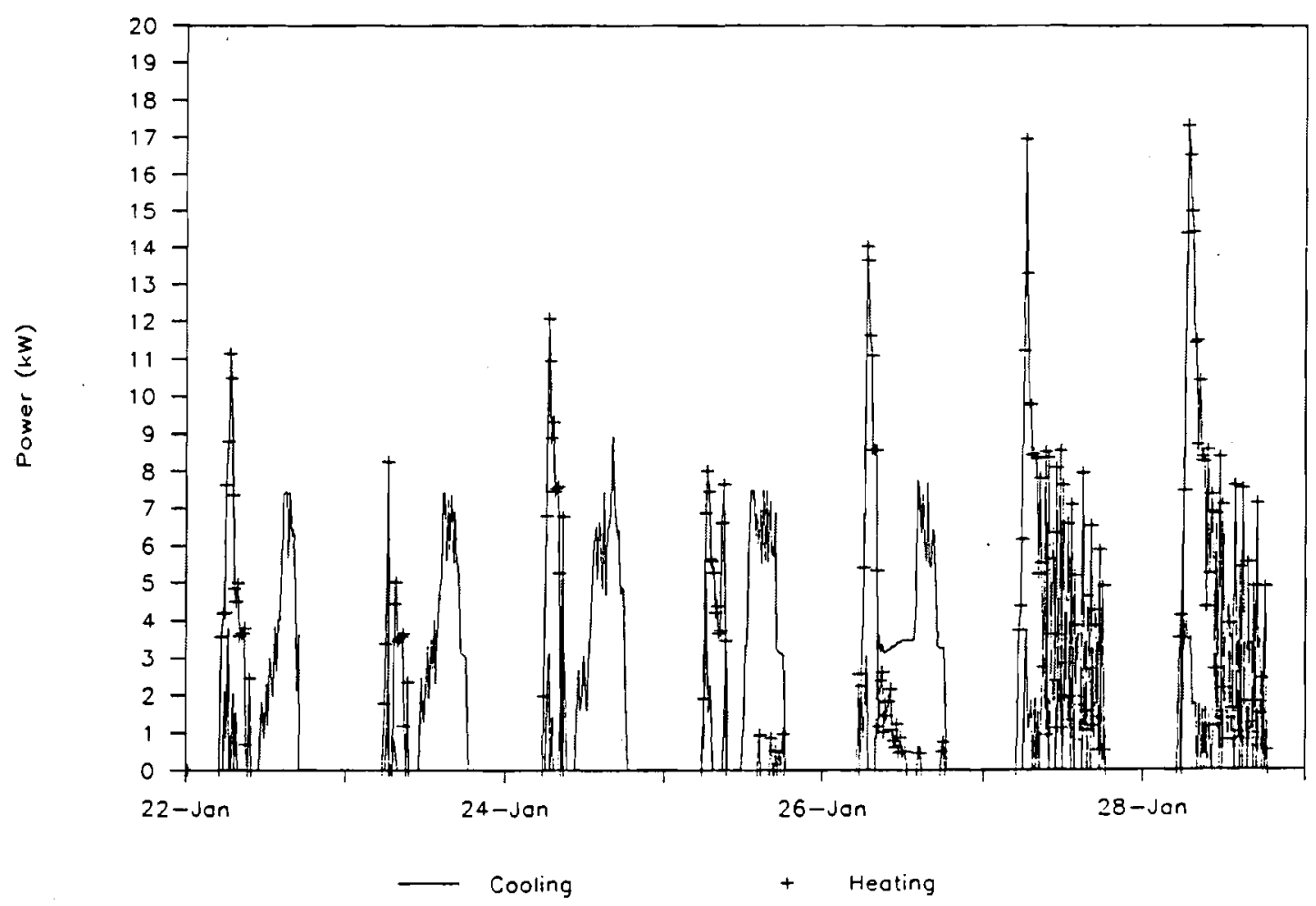

Figure 4.2. Primary Heating and Cooling Power in Building 567 for the Week of 22 January 1990

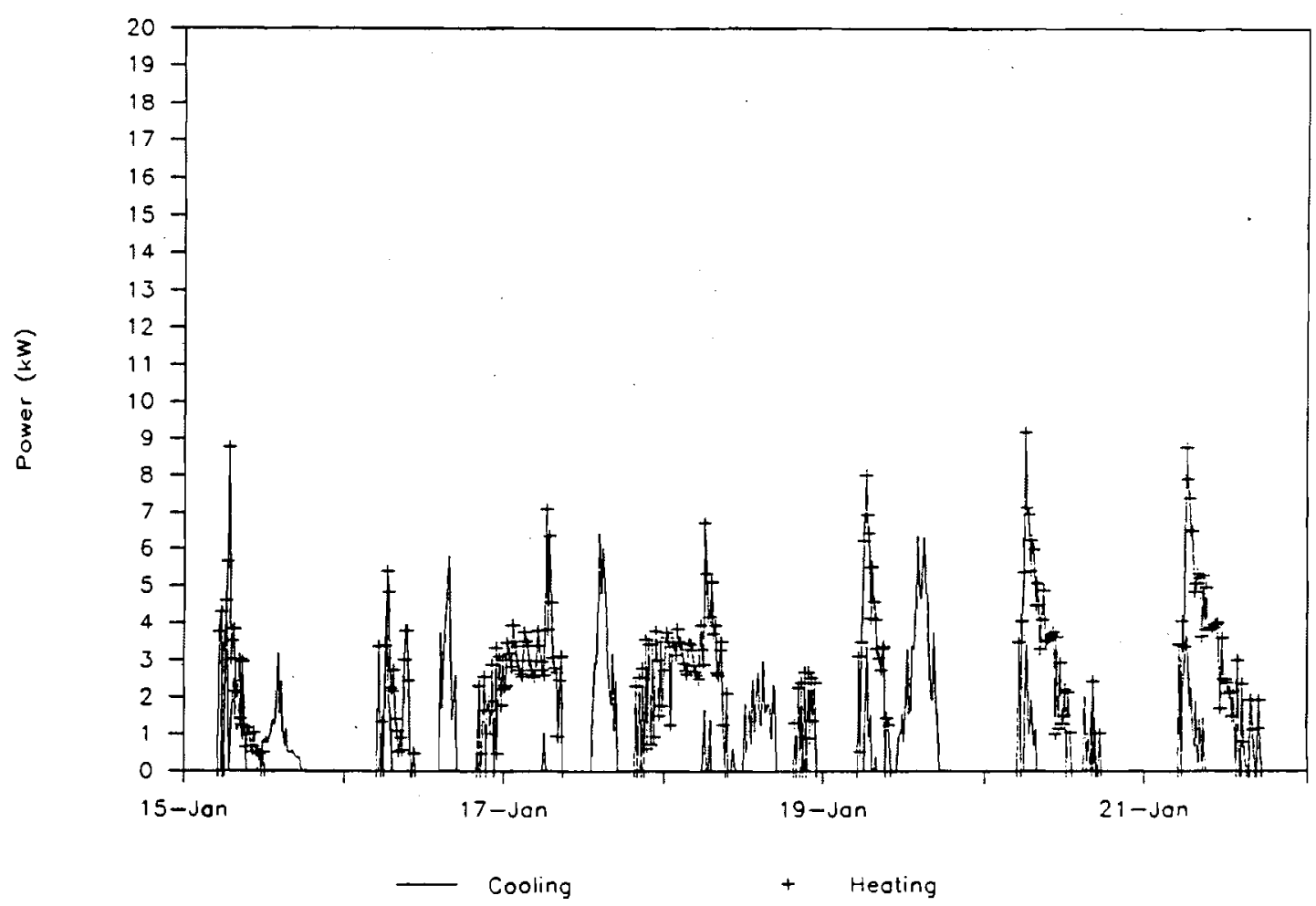

Figure 4.3. Primary Heating and Cooling Power in Building 567 for the Week of 15 January 1990 


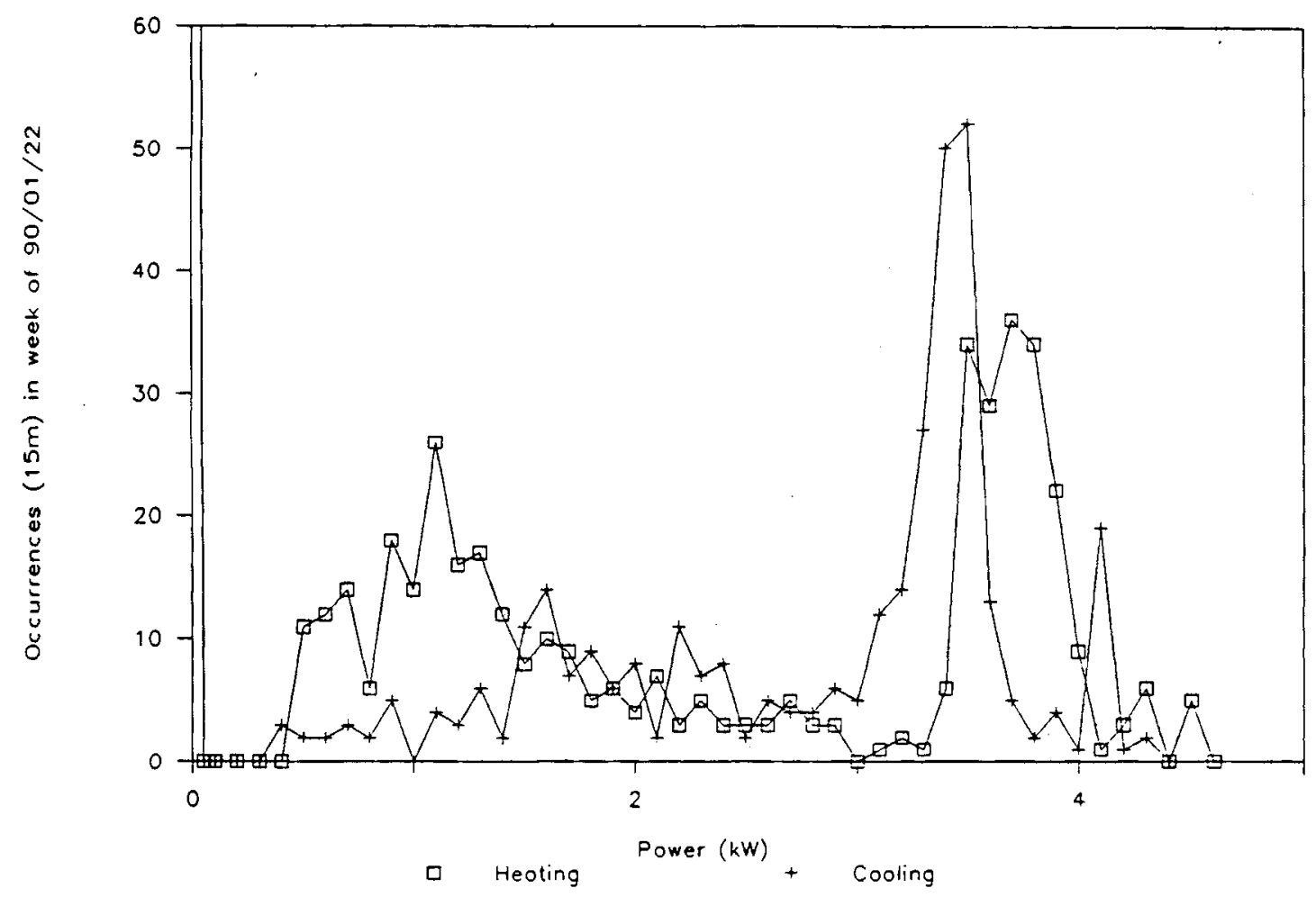

Figure 4.4. Frequency of 15-Minute Average Heat Pump Power in Building 567

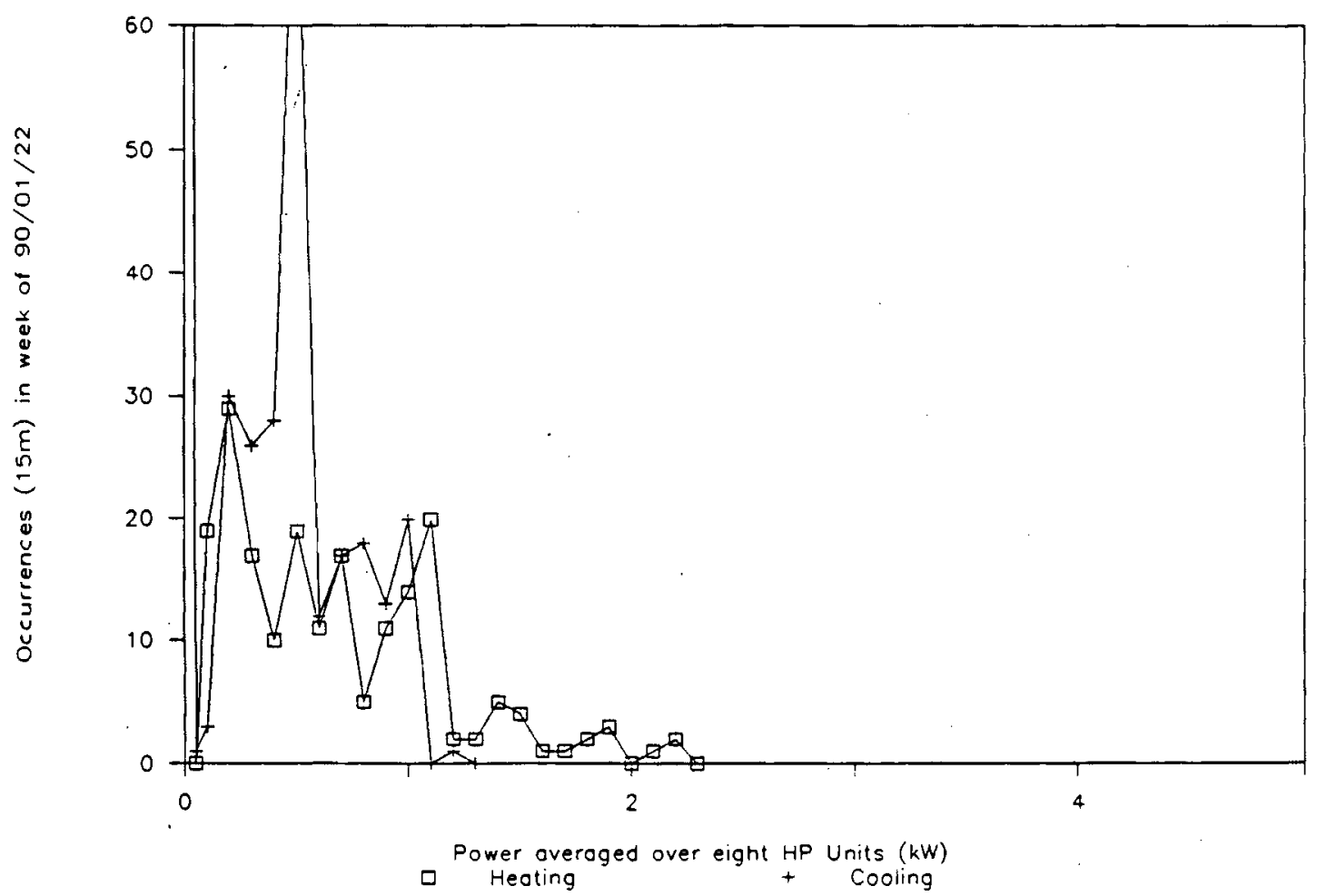

Figure 4.5. Frequency of 15-Minute Average Power for All Heat Pumps Together in Building 567 (expressed in $\mathrm{kW}$ per heat pump unit) 


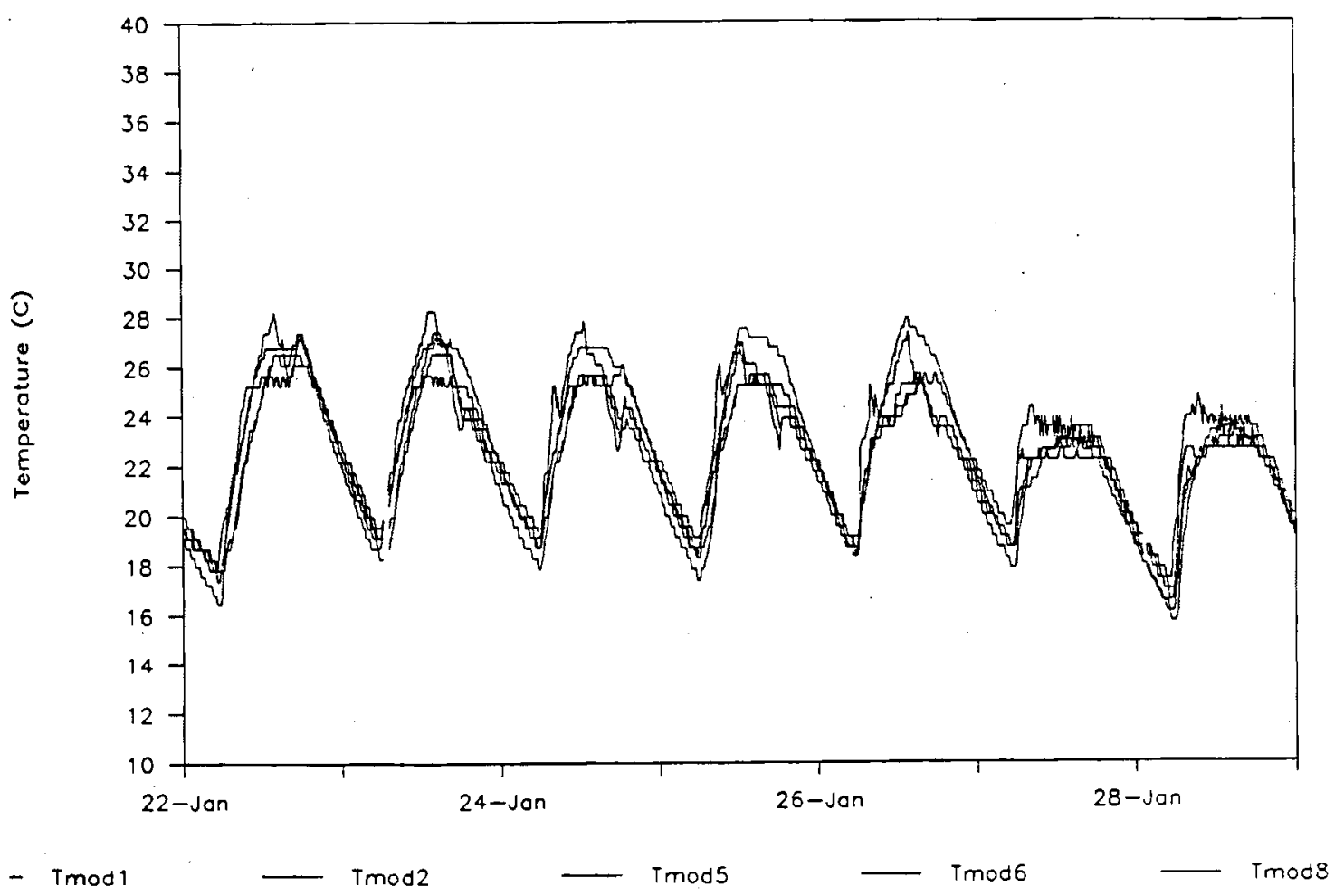

Figure 4.6. Indoor Air Temperature Histories in Modules 1, 2, 5, 6 and 8 of Building 567 for the Week of 22 January 1990

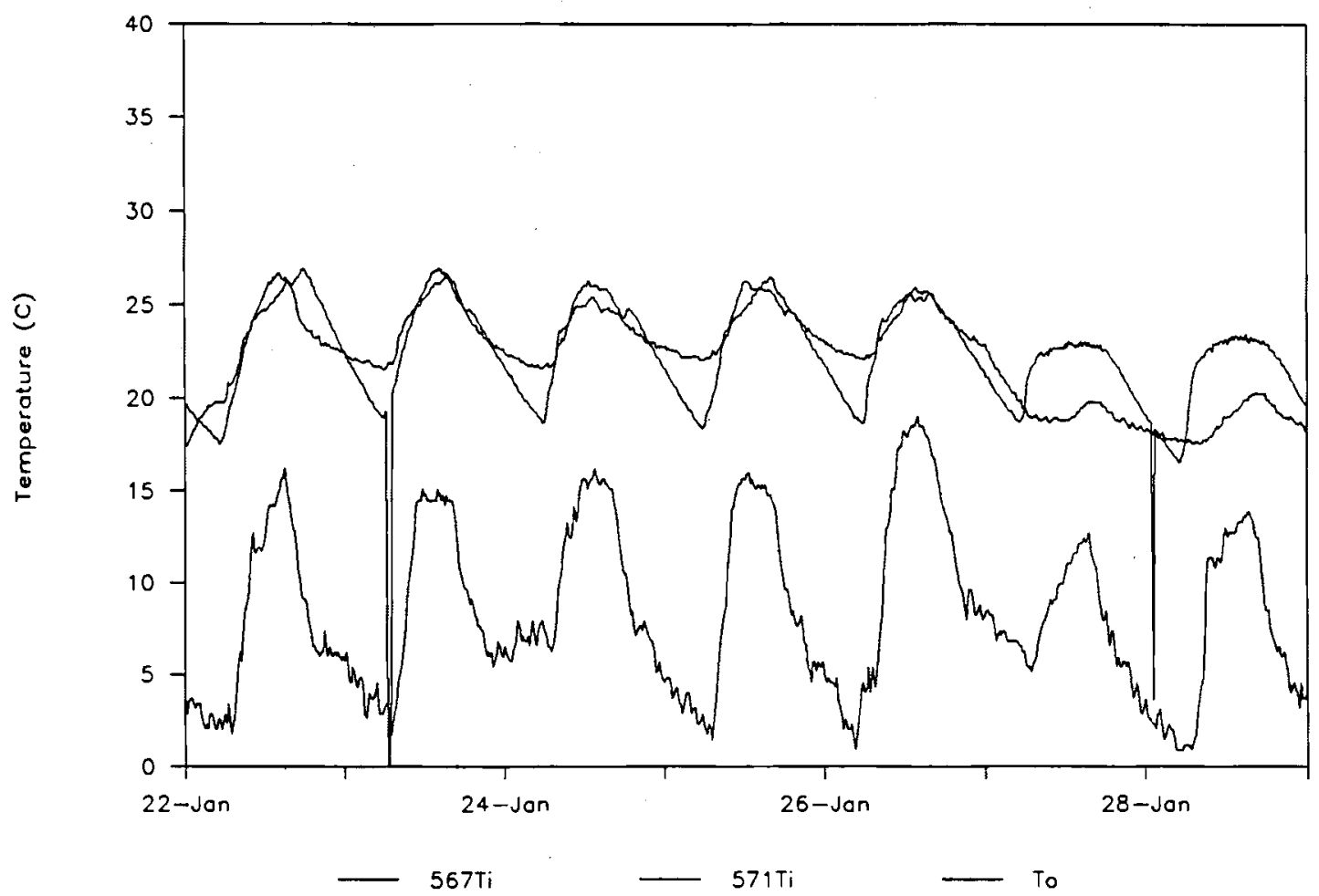

Figure 4.7. Outdoor Temperature and Average Indoor Air Temperatures in Buildings 567 and 571 for the Week of 22 January 1990 


\subsection{Long-Term Observations}

The long-term histories of daily energy use by separately monitored loads are shown in Figures 4.8 through 4.15.

Figures 4.8 and 4.9 show the heating and cooling energy for Buildings 567 and 571 on workdays. Note that for Building 567 there is a breakdown into primary heating, primary cooling and fan energy. There is also a history of daily energy waste due to simultaneous heating and cooling by heat pumps in adjacent modules. Figures 4.10 and 4.11 show the same data for non-workdays.

Figures 4.12 and 4.13 show the lighting loads, plug loads and mixed loads for Buildings 567 and 571 on workdays. Note that the loads (lighting in particular) are not as constant as expected for an office/administrative type building. The first shift in energy use occurs at the end of May 1990. This correlates with a change in work schedule adopted to reduce on-peak energy use. To gain more insight into changing energy use patterns, the daily load profiles were plotted; the profiles are discussed in the next section. Figures 4.14 and 4.15 show the historical light, plug, and mixed load data for non-workdays. The non-workday loads are much lower than workday loads and the variability is low as is typical for this building type.

Table 4.1 gives the average daily energy use and the corresponding energy-use intensity (EUI) by load for Building 567. Table 4.2 gives the corresponding data for Building 571.

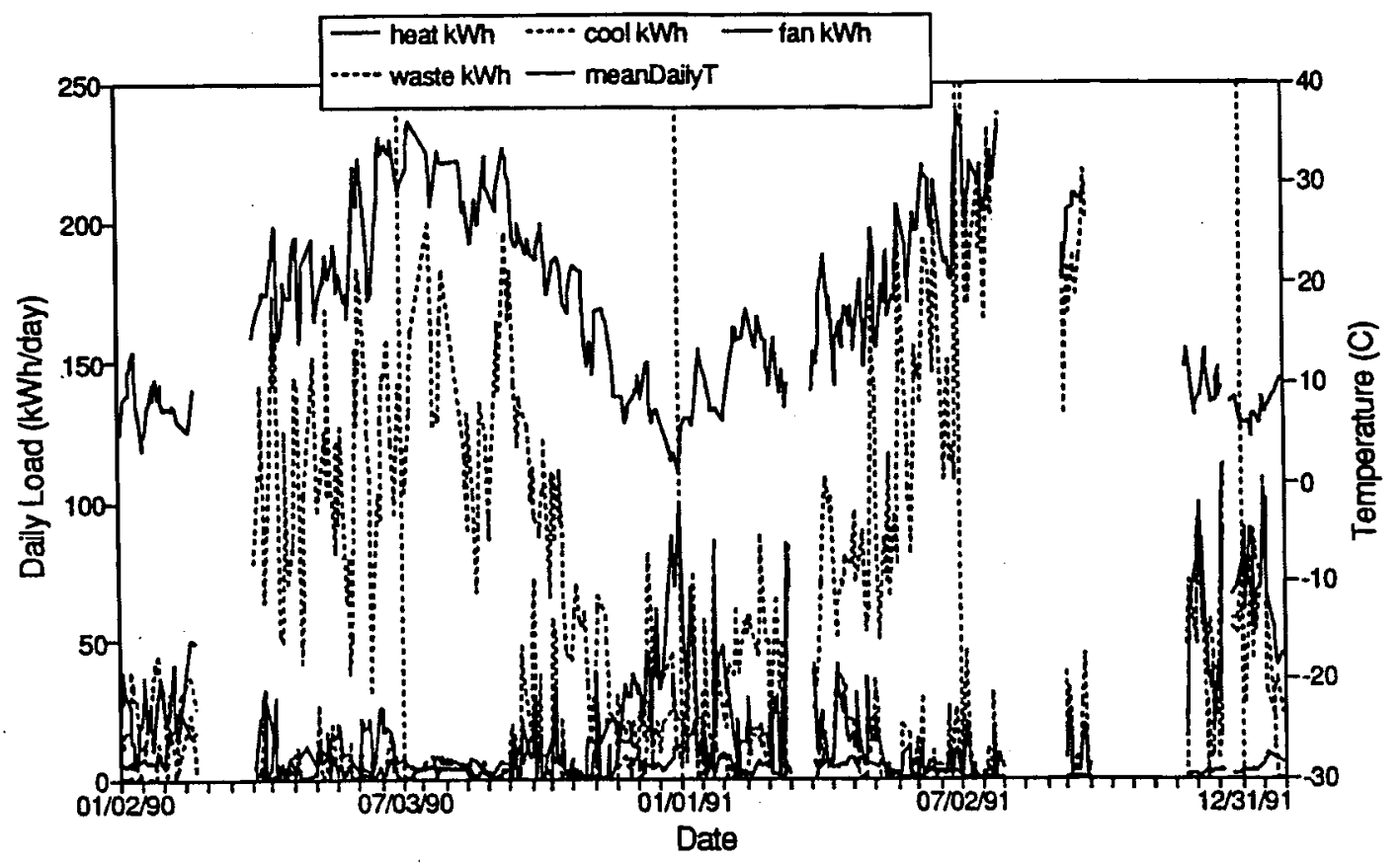

Figure 4.8. Workday Average Primary HVAC Loads in Building 567 


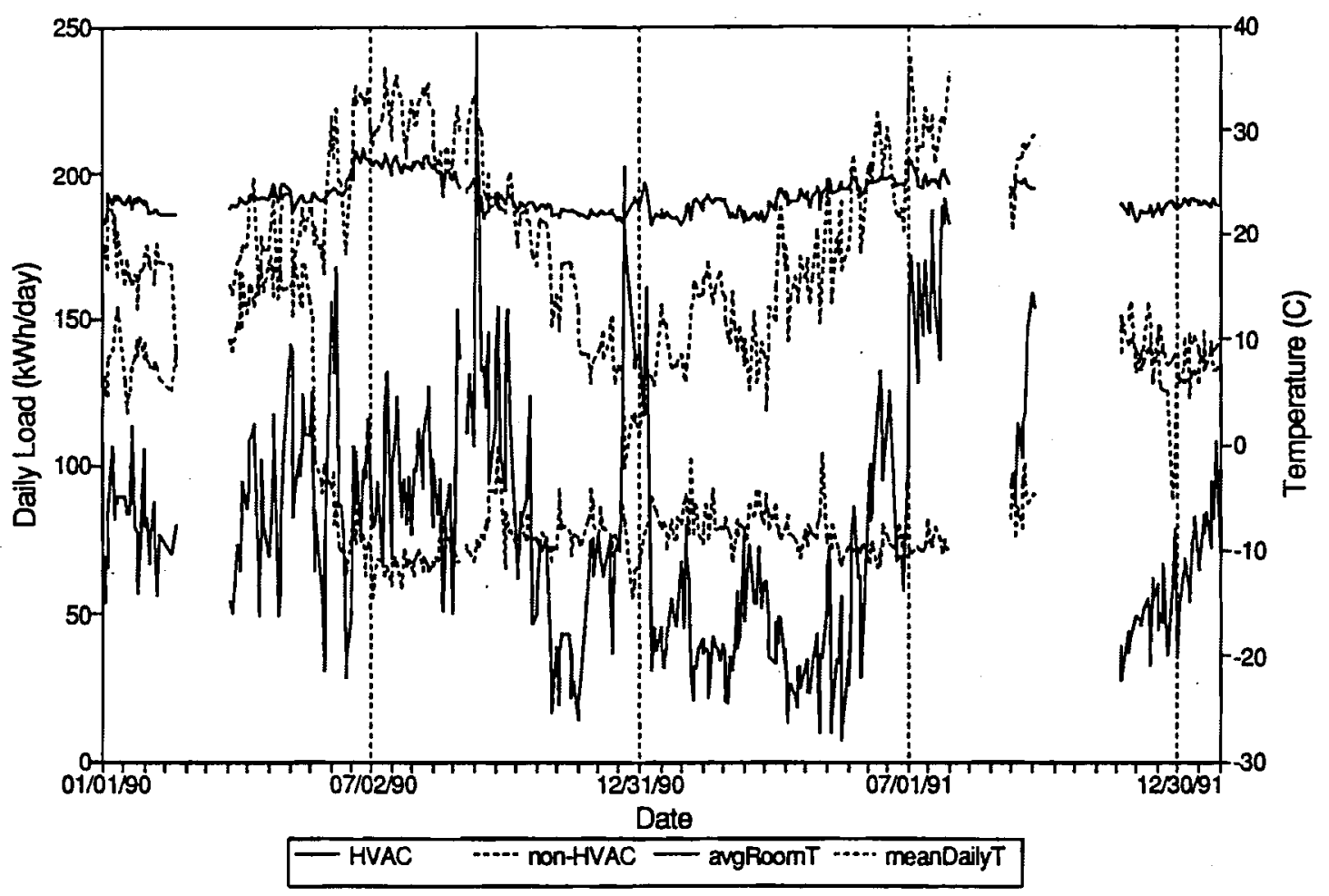

Figure 4.9. Workday Average Primary HVAC Loads in Building 571

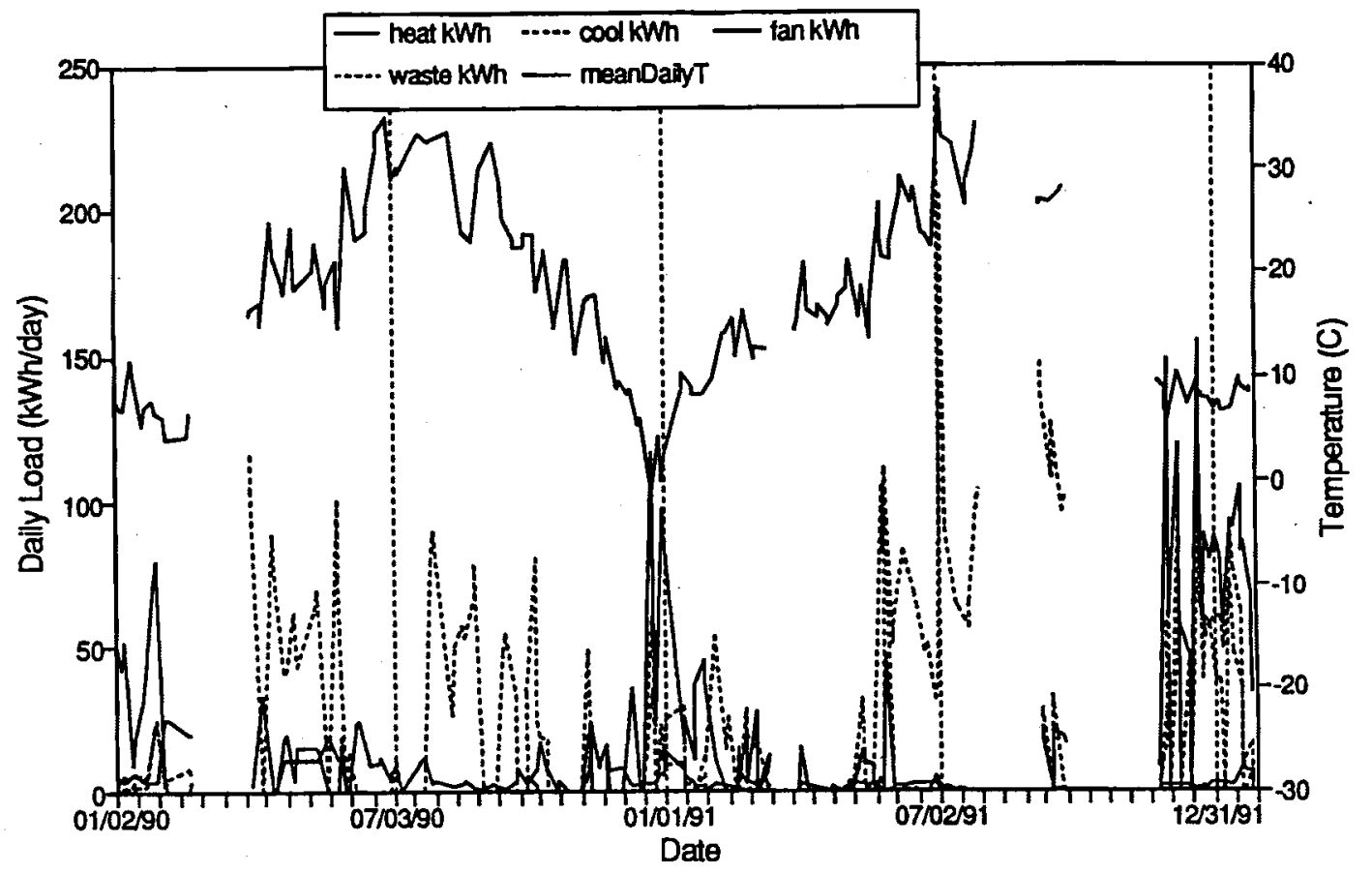

Figure 4.10. Non-Workday Average Primary HVAC Loads in Building 567 


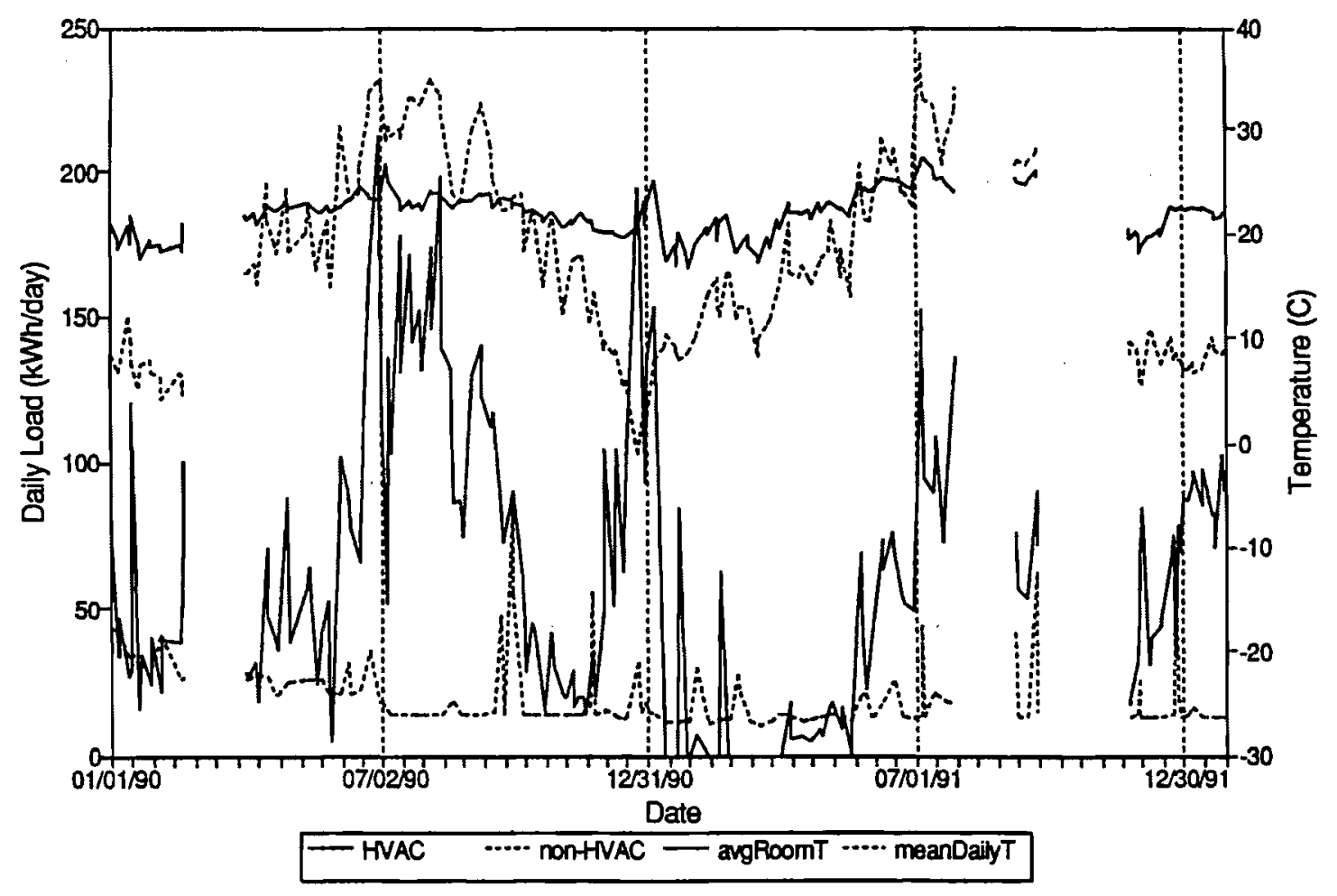

Figure 4.11. Non-Workday Average Primary HVAC Loads in Building 571

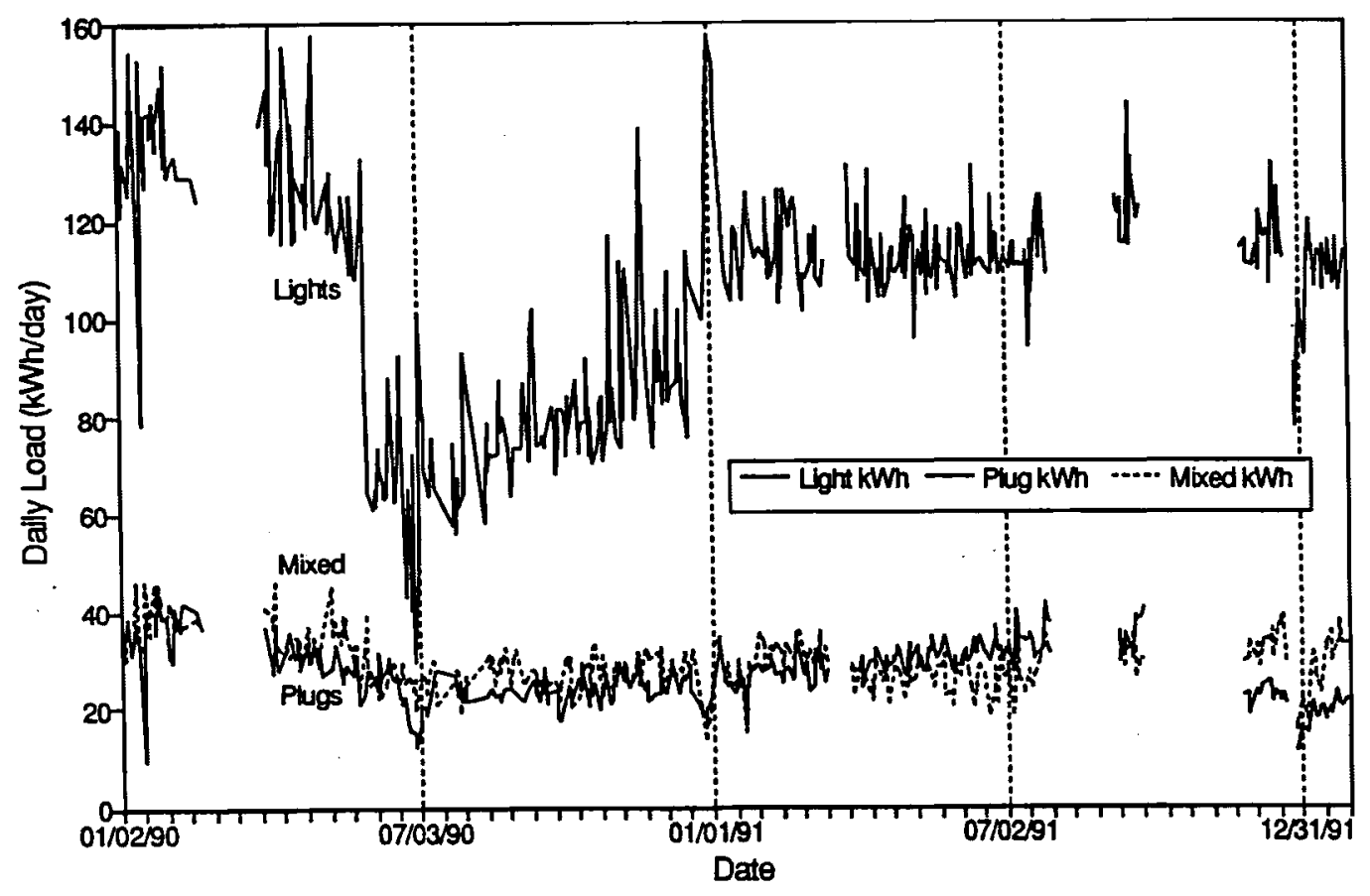

Figure 4.12. History of Workday Average Non-HVAC Loads in Building 567 


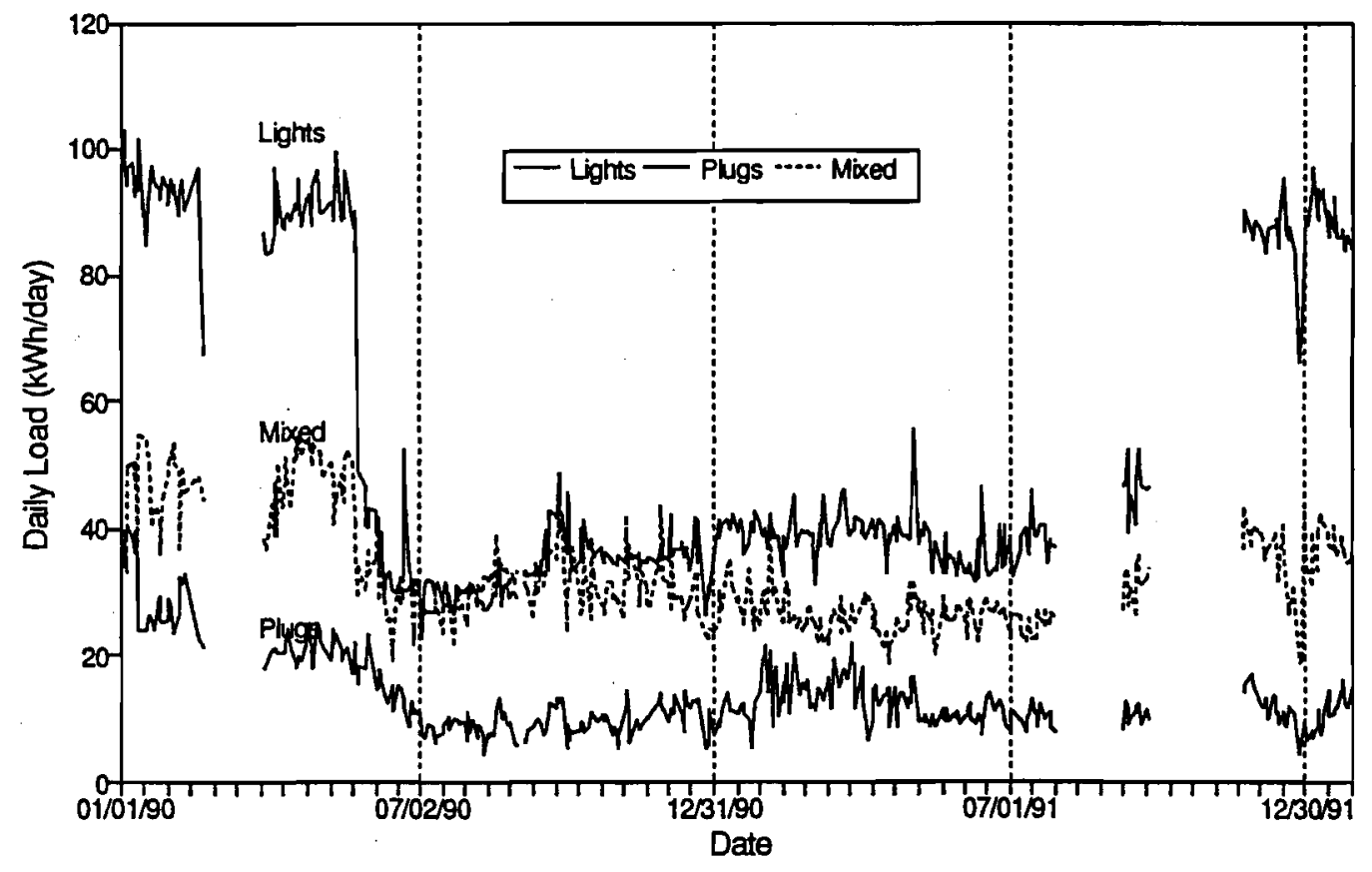

Figure 4.13. History of Workday Average Non-HVAC Loads in Building 571

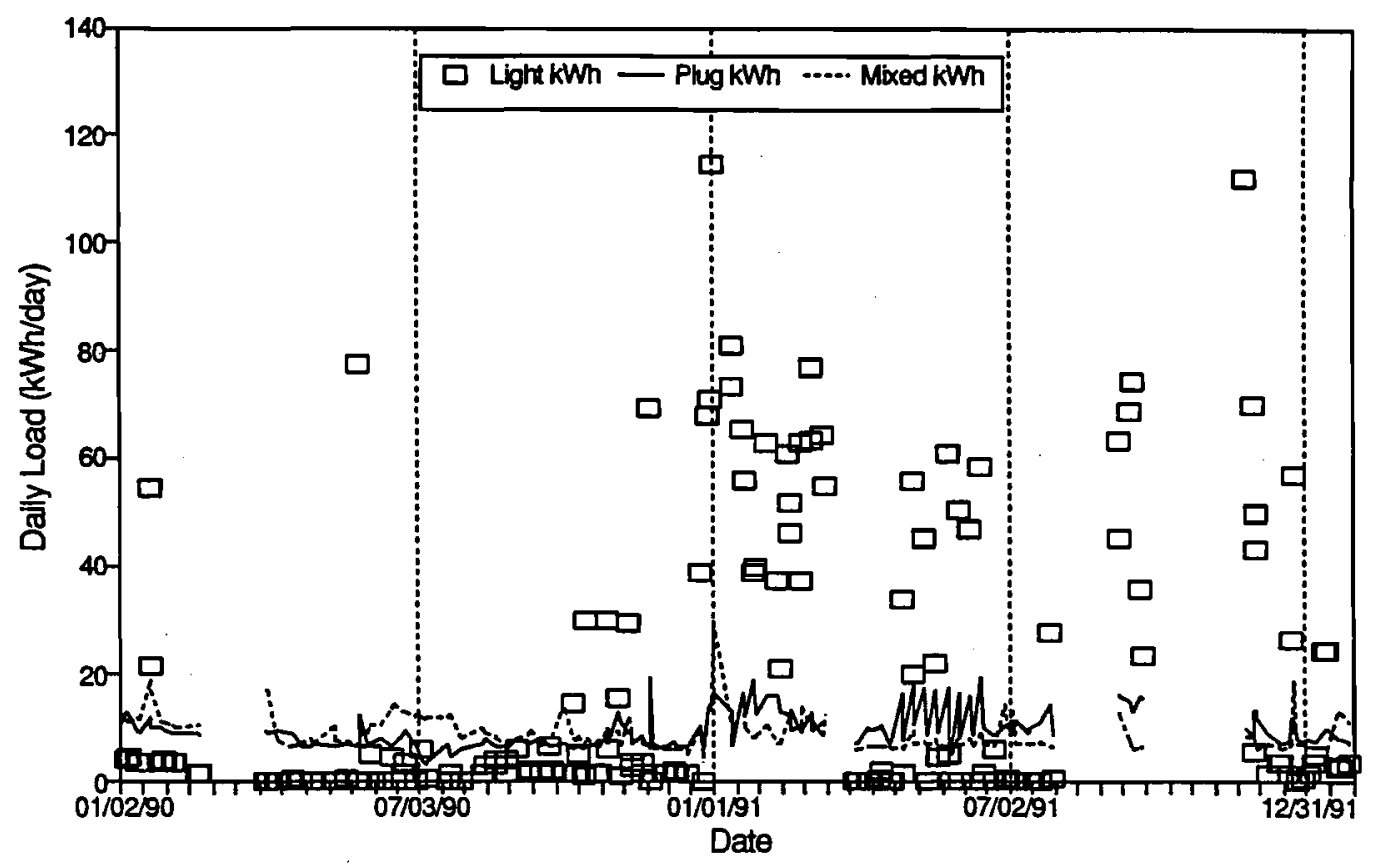

Figure 4.14. Non-Workday Average Non-HVAC Loads in Building 567 


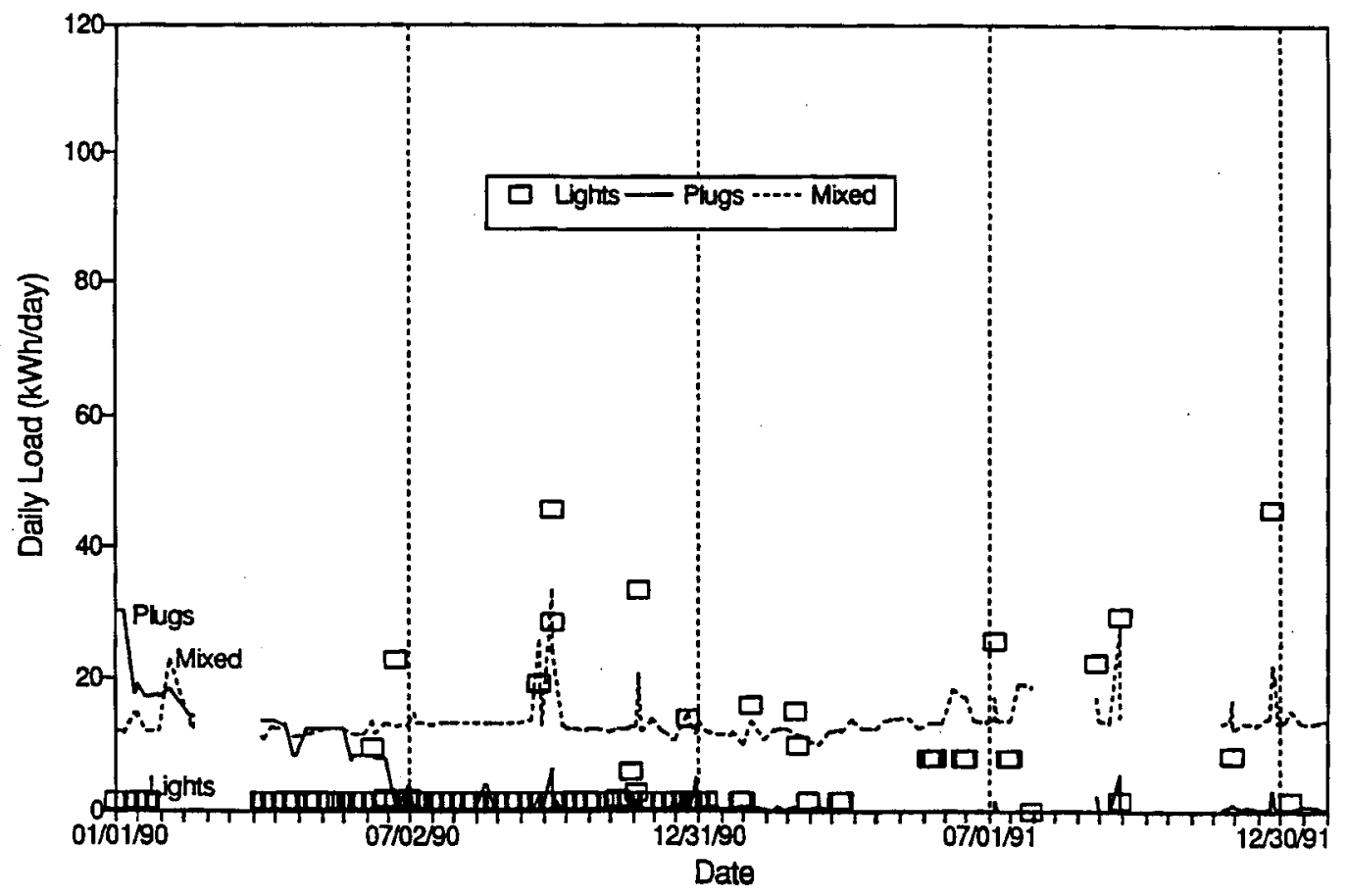

Figure 4.15. Non-Workday Average Non-HVAC Loads in Building 571

Table 4.1. Energy Use in Building 567 by End Use

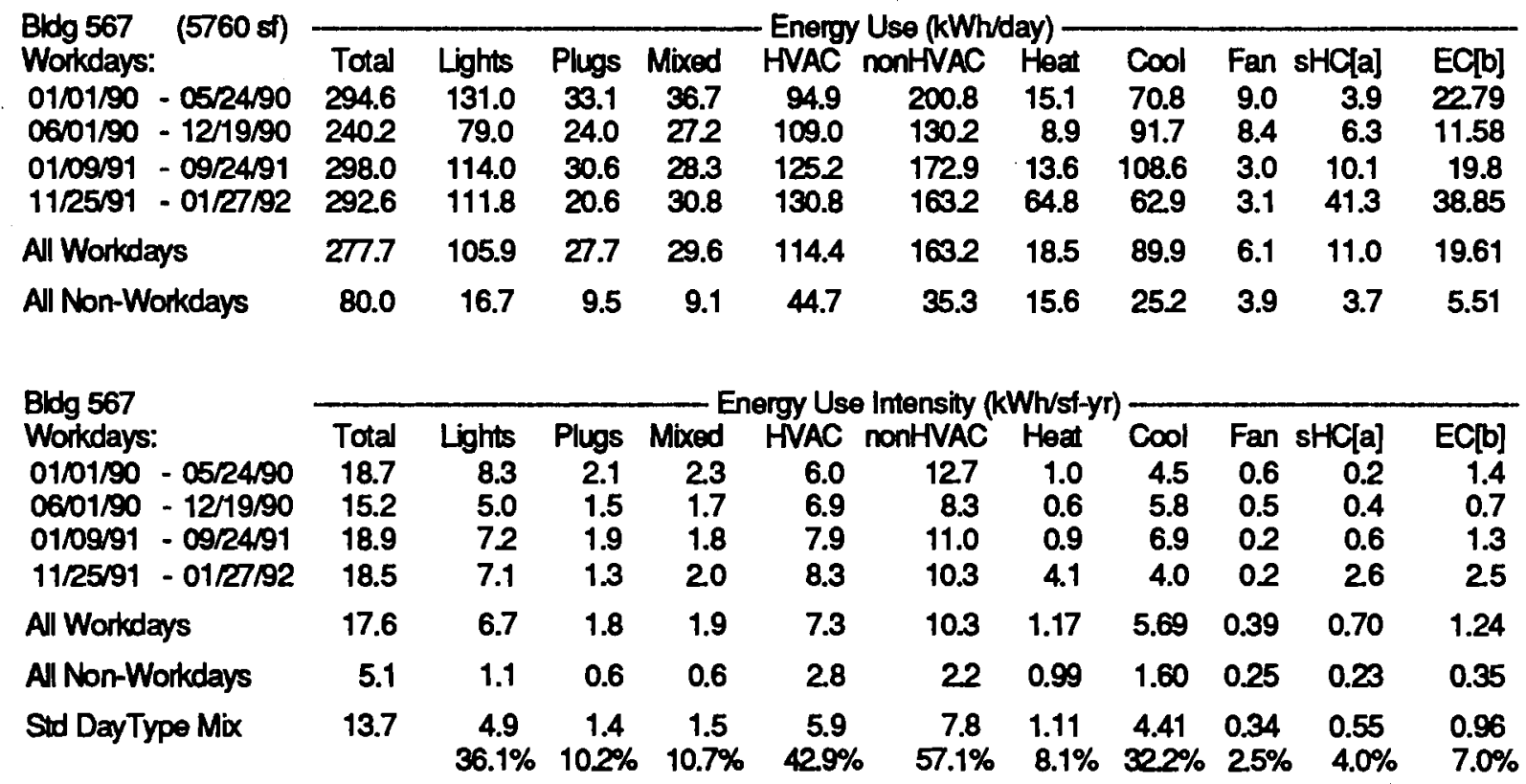

[a] primary energy for simultaneous heating and cooling

b] primary cooling energy that can be saved with economizer cooling 
Table 4.2. Energy Use in Building 571 By End Use

\begin{tabular}{|c|c|c|c|c|c|c|}
\hline $71 \quad(50$ & & & & onvive & & \\
\hline Workdays: & Total & Lights & Plugs & Mixed & ḦVAC & NAC \\
\hline $\begin{array}{ll}01 / 01 / 90 & -05 / 24 / 90 \\
06 / 01 / 90 & -12 / 21 / 90\end{array}$ & $\begin{array}{l}250.7 \\
163.7\end{array}$ & & & & $\begin{array}{l}86.4 \\
91.7\end{array}$ & \\
\hline $\begin{array}{ll}01 / 09 / 91 & -09 / 2 \\
11 / 21 / 91 & -01 / 2\end{array}$ & $\begin{array}{l}140.5 \\
184.0\end{array}$ & $\begin{array}{l}39.3 \\
87.3\end{array}$ & $\begin{array}{l}12.4 \\
11.4\end{array}$ & & $\begin{array}{l}69.7 \\
59.1\end{array}$ & $\begin{array}{r}78.6 \\
134.9\end{array}$ \\
\hline All Workdays & 1722 & 51.2 & 13.6 & 32.6 & 79.8 & 36.9 \\
\hline All Non-Workdays & 80.6 & 2.8 & 3.0 & 13.5 & 59.9 & 9.2 \\
\hline s & & & rose & Sily & & \\
\hline Workdays: & Tot & ghts & Plugs & Mixed & $A C$ & HVAC \\
\hline $\begin{array}{l}01 / 01 / 90-05 / 24 / 90 \\
06 / 01 / 90-12 / 21 / 90 \\
01 / 09 / 91-09 / 24 / 91\end{array}$ & & & & & 6.3 & $\begin{array}{r}11.8 \\
5.5 \\
57\end{array}$ \\
\hline $\begin{array}{ll}01 / 09 / 91 & -09 / 24 / 91 \\
11 / 21 / 91 & -01 / 27 / 92\end{array}$ & & & 8 & & 3 & $\begin{array}{l}5.7 \\
9.8\end{array}$ \\
\hline All Workdays & 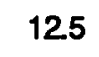 & 3.7 & 1.0 & 24 & 5.8 & 7.0 \\
\hline All Non-Workdays & -5 & 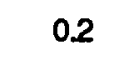 & 0.2 & 1.0 & 4.3 & 1.4 \\
\hline Std DayType Mix & 10.4 & $\begin{array}{c}2.6 \\
25.1 \%\end{array}$ & $\begin{array}{c}0.7 \\
7.2 \%\end{array}$ & $\begin{array}{c}1.9 \\
18.5 \%\end{array}$ & $\begin{array}{c}5.3 \\
51.3 \%\end{array}$ & $\begin{array}{c}5.3 \\
50.6 \%\end{array}$ \\
\hline
\end{tabular}

\subsection{Average Daily Demand Profiles}

Figures 4.16 through 4.20 show the lighting and non-HVAC (aggregate of light, plug, and mixed) load profiles for the four periods defined by the distinct changes in average non-HVAC load.

Weekday demand profiles for lighting circuits are shown in Figures 4.16 and 4.17. In Building 567, Figure 4.16, the change in workday schedule is apparent but there are also large changes in the heights of the profiles. These changes can only be explained by delamping or office vacancies. Note that daytime lighting power density is highest during $1 / 90-5 / 90$, is lowest during $6 / 90-12 / 90$, returns almost to the $1 / 90$ - 5/90 power level during 1/91 - 9/91 but drops again for 11/91 - 1/92. In Building 571, Figure 4.17, the change in workday schedule is also apparent. Here there are even larger changes in the heights of the profiles. These changes can only be explained by delamping or office vacancies. Note that daytime lighting power density is highest during $1 / 90-5 / 90$, lowest during $6 / 90-12 / 90$, and returns almost to the $1 / 90-5 / 90$ power level during 11/91 - 1/92.

Non-HVAC demand profiles for the entire monitoring period are shown in Figures 4.18 and 4.19. The weekday non-HVAC (including lights) and pure lighting profiles have very similar shape in both buildings and are also similar between buildings. However, the weekday (Figure 4.18) power densities are about $50 \%$ higher for Building 567, consistent with the observations presented earlier in Tables 4.1 and 4.2. The weekend profiles, Figure 4.19, show occasional daytime use of Building 567 but rare weekend daytime use of Building 571. Note that both buildings have a non-HVAC equipment baseload of about $0.15 \mathrm{~W} / \mathrm{ft}^{2}$ $\left(1.3 \mathrm{kWh} / \mathrm{ft}^{2}-\mathrm{yr}\right)$; these baseloads would include small service water heaters and break room refrigerators.

The relation between weekday and weekend non-HVAC demand profiles can be seen clearly in Figure 4.20. 


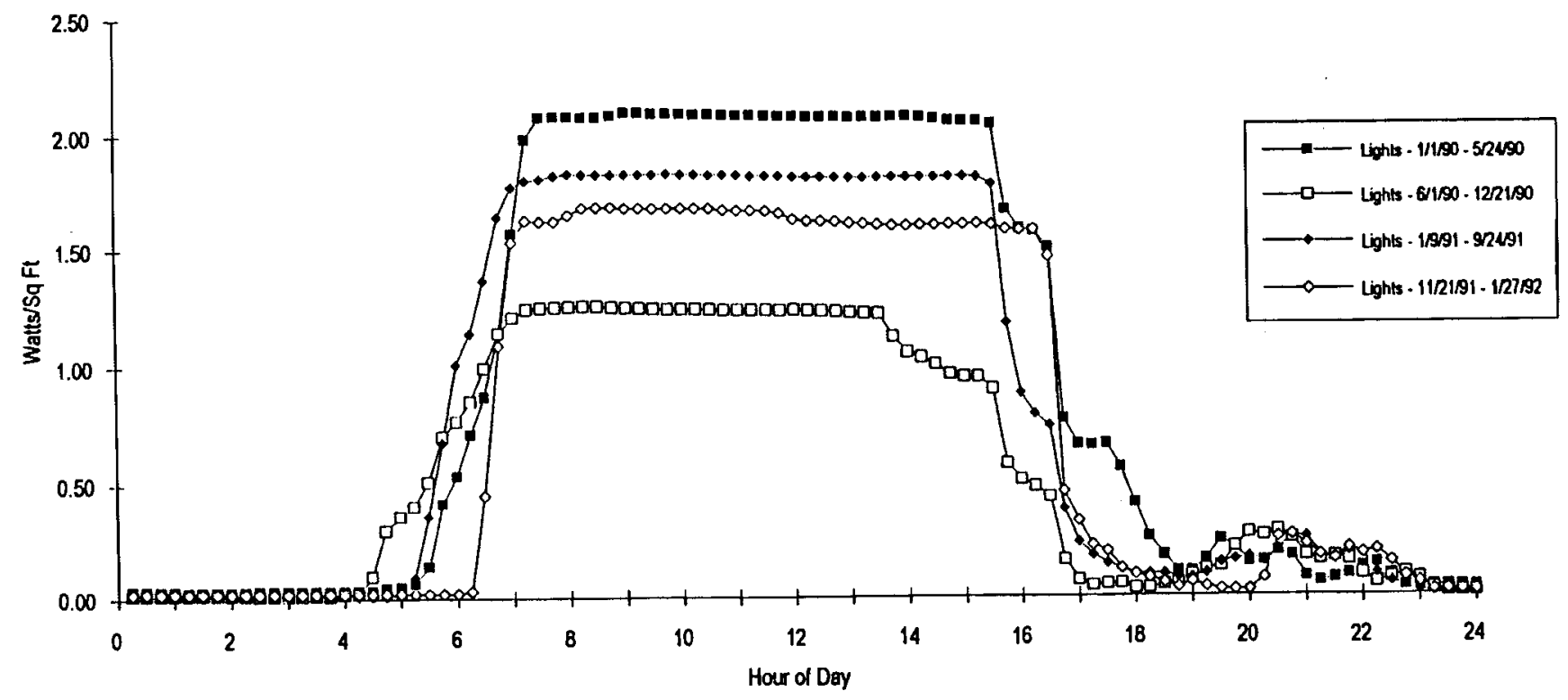

Figure 4.16. Daily Average Demand Profile in Building 567 for Pure Lighting Circuits During Four Distinct Monitoring Periods

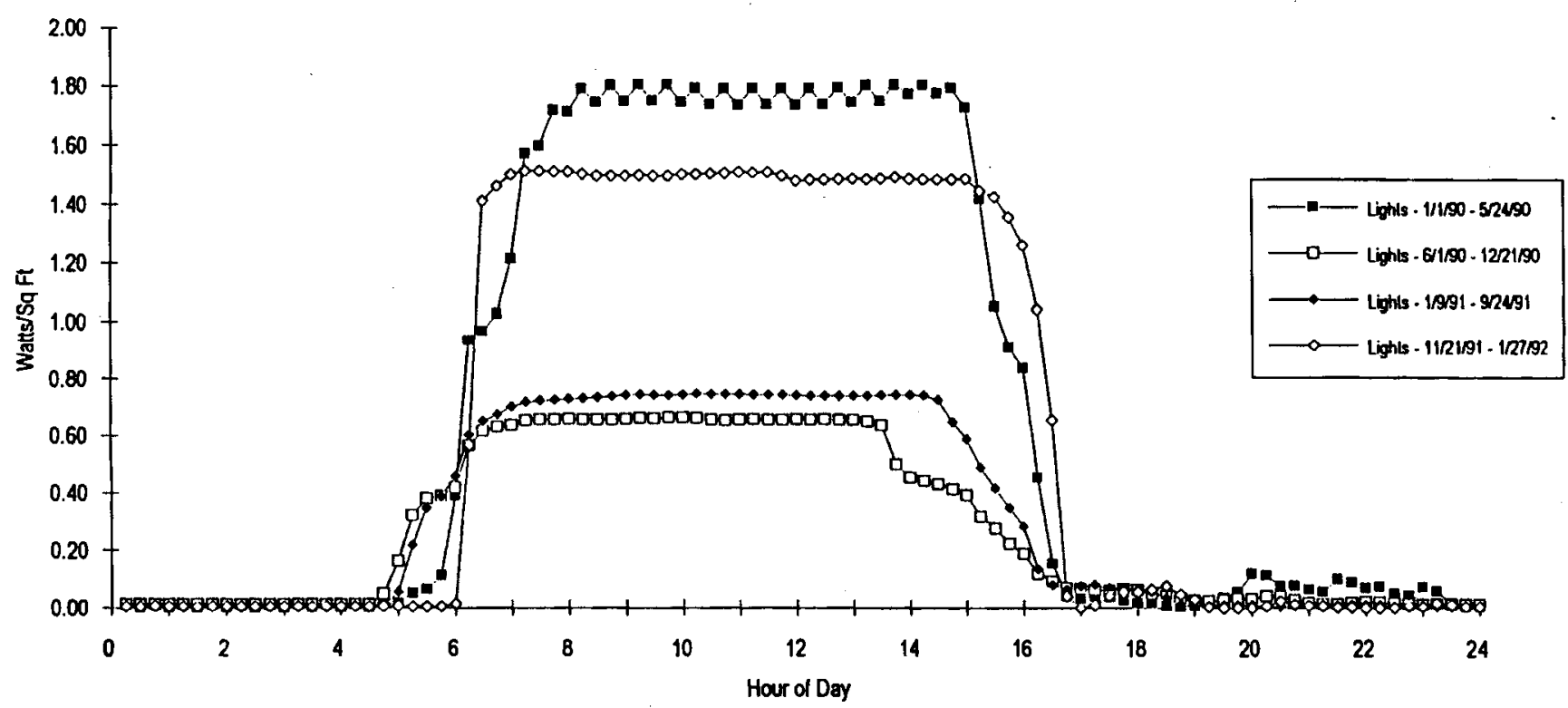

Figure 4.17. Daily Average Demand Profile in Building 571 for Pure Lighting Circuits During Four Distinct monitoring periods 


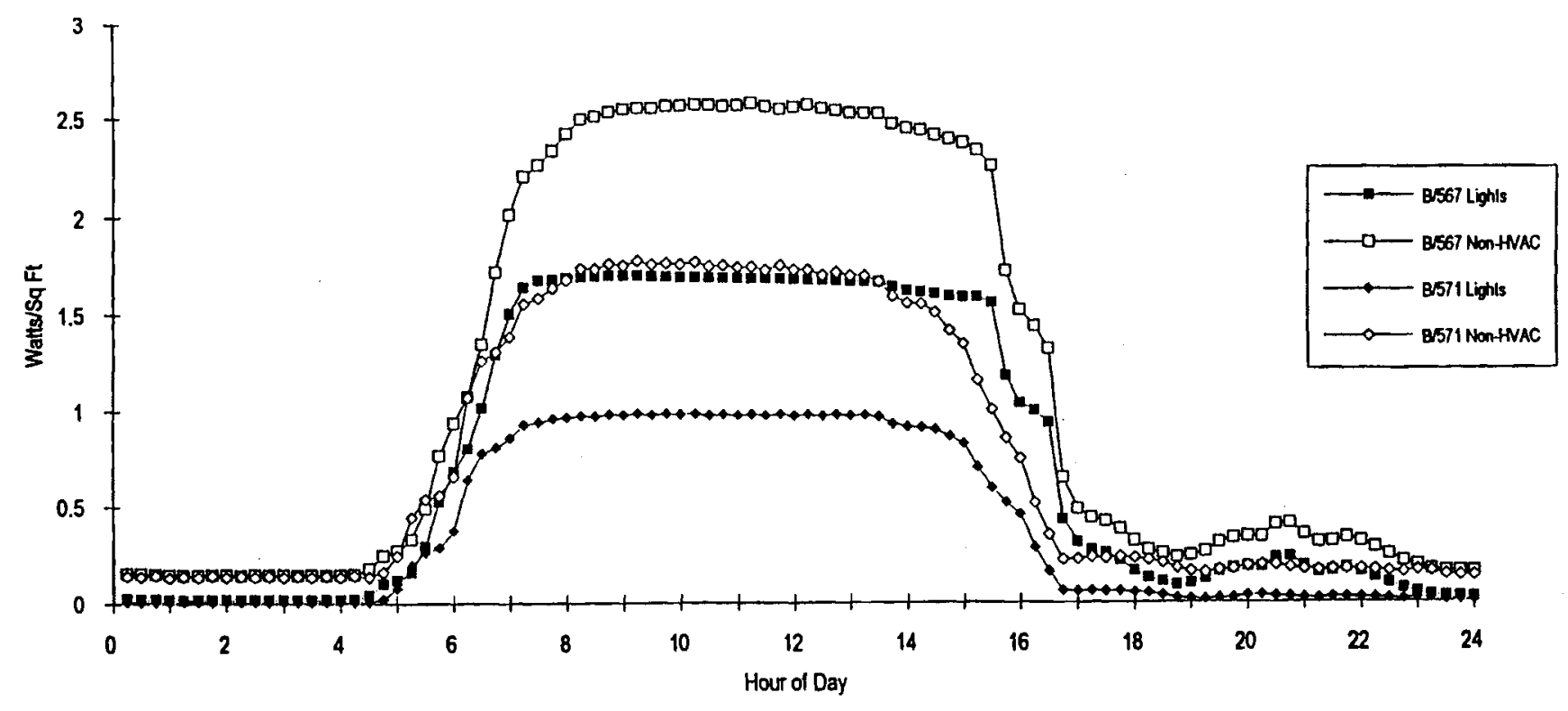

Figure 4.18. Average Weekday Demand Profiles for the Entire Monitoring Period-

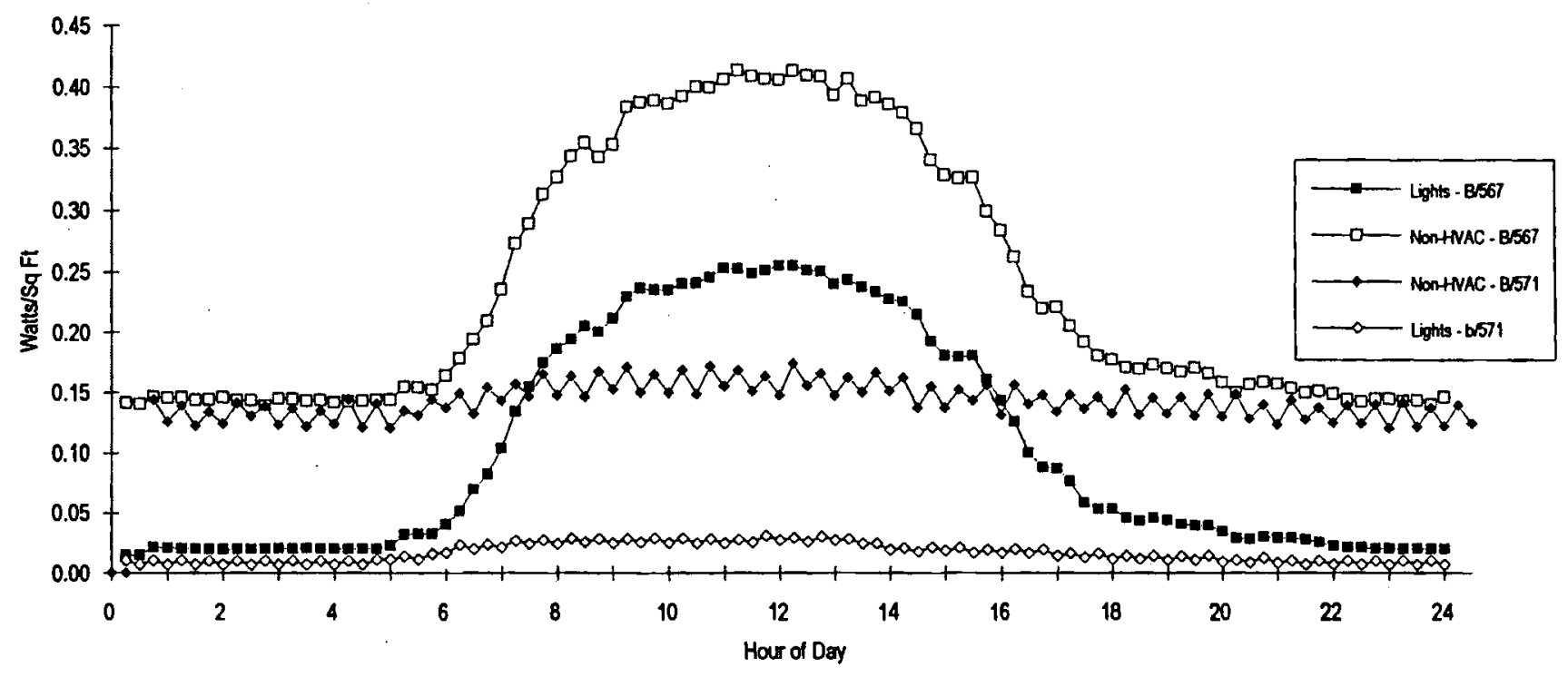

Figure 4.19. Average Non-weekday Demand Profiles for the Entire Monitoring Period 


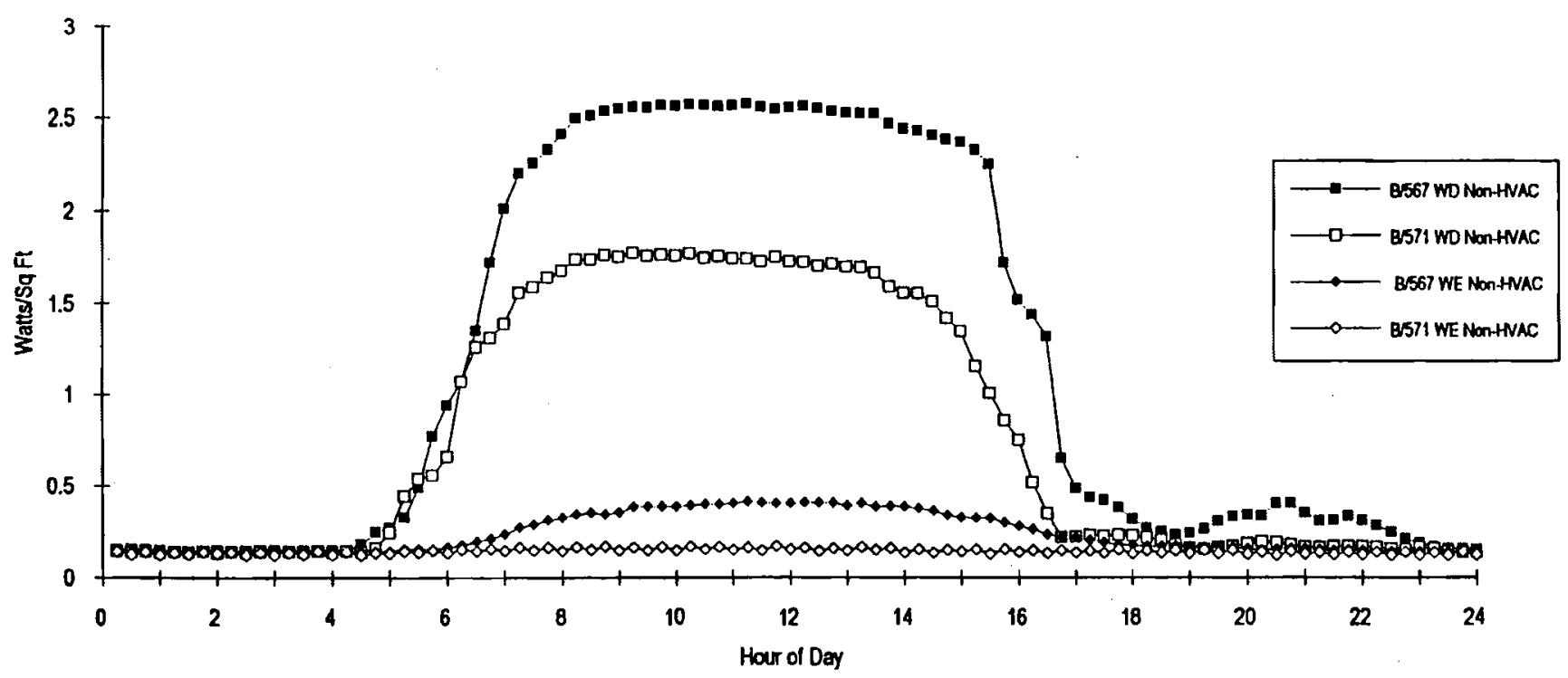

Figure 4.20. Weekday and Weekend Non-HVAC Demand Profiles for Buildings 567 and 571 


\subsection{Energy Resource Opportunities}

An energy resource opportunity (ERO) is any conservation, efficiency, or fuel-switching measure that will save energy at the site or at the primary energy source (e.g., involving the serving electric utility's raw energy mix). Six such opportunities have been evaluated for the modular buildings at Fort Irwin and are discussed in this section.

\subsection{Improved HVAC Controls}

Primary HVAC energy can be saved by implementing night and weekend setback schedules with an optimal start feature. Additional energy can be saved by including controls to prevent simultaneous heating and cooling.

Description. The modular buildings currently use separate thermostats to control the heat pumps in each module. The large number of thermostats makes implementation of night setback a difficult operation and maintenance problem. An attractive solution is to add a central controller to each building. The controller will enable heating or cooling based on the average temperature sensed by multiple sensors. This will allow the heat pumps to heat or cool but not both. With a central control deadband of $1^{\circ} \mathrm{C}$ and module thermostat deadbands of 3 to $4^{\circ} \mathrm{C}$, there will be ample margin for variation in individual setpoints to satisfy occupants' comfort criteria. At night and on weekends the central control will operate with a lower heating setpoint of 12 to $15^{\circ} \mathrm{C}$ and will disable cooling entirely. Time to recover from night setback will be estimated by an optimal start algorithm based on average indoor temperature, outdoor temperature, and daytime heating setpoint. This will allow a low night heating setpoint to be used without the penalty of having to initiate recovery on a fixed, early morning (worst case) schedule. A lower-cost alternative to the EMCS-type controller described above is a full-featured electronic thermostat wired to enable the heating and cooling modes of the individual module thermostats. Another alternative is to include sufficient inputs with the central control to measure the air temperature at each zone and completely replace the existing thermostats.

Assumptions. Elimination of simultaneous heating and cooling will save $3,200 \mathrm{kWh} / \mathrm{yr}$ in Building 567 and $2,000 \mathrm{kWh} / \mathrm{yr}$ in Building 571 . Based on the current non-workday HVAC consumption of $37,000 \mathrm{kWh} / \mathrm{yr}$ and the workday night heating consumption of $10,000 \mathrm{kWh} / \mathrm{yr}$, night and weekend setback with optimal start should save at least $16,000 \mathrm{kWh} / \mathrm{yr}$. Setback and optimal start savings accrue at a rate of $\$ 0.05 / \mathrm{kWh}$ and $\$ 2.15 / \mathrm{kW}$-mo; simultaneous heating and cooling prevention accrues savings of $\$ 0.10 / \mathrm{kWh}$ and about $\$ 6.00 / \mathrm{kW}-\mathrm{mo}$. A load factor of 0.5 is assumed for demand savings calculations.

The annual energy saved by night and weekend setback costs $\$ 800$, with associated demand charges of $\$ 50$; the annual energy saved by prevention of simultaneous heating and cooling costs $\$ 500$, with associated demand charges of $\$ 250$. The total annual savings in the two buildings is therefore about $\$ 1,600$.

The small commercial building EMCS control market is large and very competitive. A number of manufacturers offer 16-point (e.g., 8 analog in, 8 digital out) units for under $\$ 1,500$. Four temperature sensors and one outdoor temperature sensor will cost $\$ 300$, and installation labor and programming will cost $\$ 500$ per building assuming 10 or more buildings are involved. Wiring to existing thermostats will cost about $\$ 100$, and thermostat replacement (if necessary) will cost about $\$ 100$ each, including labor. Maximum total cost is therefore about $\$ 3,200$ per building. Note that the cost to expand the EMCS 
controller and add four additional room temperature sensors may be no more than the cost to replace all thermostats.

Result. The first cost to implement improved controls in the two buildings is about $\$ 6,400$. Annual energy savings of about $13,000 \mathrm{kWh}$ and about $\$ 350 / \mathrm{yr}$ in demand charges will result. The net present value $^{(a)}$ (NPV) of the measure is $\$ 12,967$ and the savings-to-investment ratio ${ }^{(b)}$ (SIR) is 3.03 .

\subsection{Two-Speed Fan Motors}

Description. Each heat pump has a supply air fan that operates continuously during occupied hours. A two-speed fan can be operated at two-thirds speed during occupied hours when there is no heating or cooling load. The measure requires replacement of the fan motor and installation of a relay to select high speed only when the heat pump compressor is on.

Assumptions. The fans use over $4,000 \mathrm{kWh} / \mathrm{yr}$ during fan-only operation. This can be reduced by $2,600 \mathrm{kWh} / \mathrm{yr}$ by replacing the fan motors with two-speed motors. The value of the energy savings is $\$ 260$, but the associated demand savings is only about $\$ 25 / y r$ because most of the fans will be running at high speed during the summer monthly basewide peaks.

Result. The first cost to retrofit the heat pump units with two-speed supply air fans in the two buildings is about $\$ 3,450$. Annual energy savings of about $2,600 \mathrm{kWh}$ and about $\$ 25 / \mathrm{yr}$ in demand charges will result. The NPV of the measure is $\$ 1,144$ and the SIR is 1.33 .

\subsection{Two-Speed Compressors}

Description. The existing heat pumps have single-speed compressors. A heat pump equipped with a two-speed compressor operates more efficiently at part load by obtaining much closer approach temperatures in the evaporator and condenser heat exchangers and by dissipating less energy in the form of refrigerant loop friction losses. A two-stage expansion valve and two-stage room thermostat controls must also be provided with this retrofit.

Assumptions. Heat pumps can satisfy the loads $90 \%$ of the time at $60 \%$ of current capacity. Energy use under these conditions will be reduced by $25 \%$ in heating mode and $30 \%$ in cooling mode. This will reduce annual HVAC energy in the two buildings from $60,000 \mathrm{kWh}$ to $44,000 \mathrm{kWh}$, for a savings of $\$ 1,500$. The cost of a two-speed, three-ton compressor is $\$ 400$; installation labor cost is $\$ 150$; additional controls will cost about $\$ 200$, installed, per heat pump unit. The retrofit will therefore cost $\$ 11,250$ for Buildings 567 and 571.

(a) Net present value (NPV) is the difference between the present value (PV) of net savings over the life-cycle cost analysis period and the initial cost of the measure. The PV of net savings is the difference between the sum of PVs of all costs, including energy, to operate and maintain the baseline plant and the sum of PVs of all costs to operate the alternative plant.

(b) Savings-to-investment ratio (SIR) is the ratio of first cost to the PV of gross savings. The PV of gross savings equals the first cost plus the NPV. 
Result. The first cost to retrofit with two-speed compressors in the two buildings is about $\$ 11,600$. Annual energy savings of about $16,000 \mathrm{kWh}$ and about $\$ 370 / \mathrm{yr}$ in demand charges will result. The NPV of the measure is $\$ 21,743$ and the SIR is 2.87 . Use of smaller compressors, based on the peak load data reported herein, should be considered if this ERO is implemented. Another option to be considered is replacement of each entire heat pump unit by a high-efficiency unit with a two-speed or variable-speed compressor and fans. Though not evaluated in this study, utility incentives may be available for this option.

\subsection{Lighting Retrofit}

Description. Lighting use during occupied periods was initially $3.0 \mathrm{~W} / \mathrm{ft}^{2}$. The potential for delamping observed in a lighting survey (Armstrong 1990) appears to have been achieved for about six months but the lighting load intensity later increased, indicating that the reduced intensity was probably due to office vacancy rather than delamping. The lighting level reductions recommended in Armstrong (1990), together with conversion of the fixtures to T-8 technology will reduce the power density for lighting to about 1.8 $\mathrm{W} / \mathrm{ft}^{2}$. The lighting technology retrofit should be undertaken, and its evaluation is presented in a forthcoming assessment report. ${ }^{(2)}$

\subsection{White Roof Coating}

Description. The existing roof is a black synthetic rubber membrane. White reflective roof coating materials are available to reduce heat gains from absorbed solar radiation.

Assumptions. Solar energy incident on the two buildings amounts to about $2,000,000 \mathrm{kWh}$ per year. About $2 \%$ of this, or $40,000 \mathrm{kWh} / \mathrm{yr}$, contributes directly to the cooling load. The measured annual cooling load for the two buildings is $113,000 \mathrm{kWh}$, based on an assumed COP of 2. White roofs will eliminate at least half of the $40,000 \mathrm{kWh} / \mathrm{yr}$ thermal load, for an annual-mostly on-peak-electric load savings of $8,000 \mathrm{kWh}$, which corresponds to energy bill savings of $\$ 800$ and associated demand savings of $\$ 250$. The cost of coating the roof is estimated to be $\$ 1.00 / \mathrm{ft}^{2}$; the total cost for the two buildings is therefore $\$ 10,800$. Renewal of the coating at 5-year intervals is assumed.

Result. The first cost to apply a reflective roof coating to both buildings is about $\$ 10,800$. Annual energy savings of about $8,000 \mathrm{kWh}$ and about $\$ 250 / \mathrm{yr}$ in demand charges will result. The NPV of the measure is $\$ 6,125$ and the SIR is 1.57 .

\subsection{Economizer Cooling}

Description. Economizer cooling can be added to the existing system in a number of ways. The simplest system would involve one economizer damper retrofit package per heat pump. However, such a retrofit may not be feasible due to the compact nature of the heat pump units. We therefore consider a system that adds a filtered outdoor air fan unit, an exhaust fan unit, and an EMCS unit and variable-speed

(a) Hadley, D. L., D. R. Dixon, J. M. Keller, E. E. Richman, S. A. Shankle, R. R. Wahlstrom, Fort Irwin Integrated Resource Assessment-Volume 3: Resource Assessment, Draft Report (1993), Pacific Northwest Laboratory, Richland, Washington. 
motor controller for each four modules. A back-draft damper will be provided at each heat pump supply air outlet and a motorized damper will be installed where the outside air duct branches to each of the four supply air ducts. Each exhaust fan will be located at the center of the roof area of the module it serves and will remove air directly from the ceiling plenum. The EMCS will monitor the existing thermostat signals, as well as exhaust and outside air temperatures and relative humidities and will control the new supply and exhaust fan speeds and open or close the motorized dampers accordingly.

Assumptions. Energy and demand savings were calculated from the monitored compressor loads, after eliminating simultaneous heating and cooling, by applying a nominal cooling COP of 2.5 and assuming a supply air flow rate of $1000 \mathrm{cfm}$ per supply fan. On this basis, economizer cooling will save about $7,140 \mathrm{kWh} / \mathrm{yr}$ on workdays and $2,020 \mathrm{kWh} / \mathrm{yr}$ on non-workdays in Building 567 . Workday savings accrue at the rate of $\$ 0.092 / \mathrm{kWh}$, and the non-workday savings accrue at the rate of $\$ 0.052 / \mathrm{kWh}$. Demand savings of about $70 \mathrm{~kW}$-months per year will also accrue at a weighted average rate of $\$ 4.55$ per kW-month.

The costs for the economizer system are as follows: outside air fan (2): $\$ 1,700$; outside air ductwork, installed: $\$ 2,160$; motorized dampers (8): $\$ 1,600$; exhaust fan with backdraft damper and curb, installed (2): \$2,140; variable-speed drive, installed (2): \$2,376 (Armstrong et al. 1993b); temperature and RH sensors, installed (3): \$375; EMCS unit (2) \$3,000; EMCS sensor and actuator interface: \$850.

Result. The estimated first cost for the retrofit is $\$ 14,200$. Annual energy and demand savings are $\$ 762$ $+318=\$ 1,080 / y r$. The NPV of the measure is $\$ 83$ and the SIR is 1.01 .

\subsection{Summary of EROs}

Life-cycle costs of the five EROs evaluated above are summarized in Table 5.1. The NPVs and SIRs were computed using BLCC (building life-cycle cost) version 3.2 for 1993 (Petersen 1992; Ruegg and Petersen 1987; NBS 1987; NIST 1993). There are some interactions that will reduce the attractiveness of some EROs and increase the attractiveness of others. Estimates of these interactive effects are reflected in the modified SIR (MSIR) values. 
Table 5.1. Present Value of Alternative Projects Shown in Ascending Order of Initial Cost

\begin{tabular}{||l|c|c|c|c||}
\hline \multicolumn{1}{|c|}{ Project Name } & $\begin{array}{c}\text { Initial } \\
\text { Cost (PV) }\end{array}$ & $\begin{array}{c}\text { Net Present } \\
\text { Value (NPV) }\end{array}$ & SIR & MSIR \\
\hline $\begin{array}{l}\text { Modular Building Base } \\
\text { Case }\end{array}$ & $\$ 0$ & $\$ 0$ & & \\
\hline Two-Speed Supply Fans & $\$ 3,450$ & $\$ 1,144$ & 1.33 & 1.4 \\
\hline $\begin{array}{l}\text { Improved HVAC Controls } \\
\text { Two-Speed hp } \\
\text { Compressors }\end{array}$ & $\$ 11,625$ & $\$ 21,743$ & 2.87 & 2.0 \\
\hline Reflective Roof Coating & $\$ 10,800$ & $\$ 6,125$ & 1.57 & 1.2 \\
\hline $\begin{array}{l}\text { Economizer Cooling } \\
\text { (B567) }\end{array}$ & $\$ 14,200$ & $\$ 83$ & 1.01 & 1.5 \\
\hline
\end{tabular}




\subsection{Conclusions and Recommendations}

The electric demand monitoring results of Section 4 and the analysis of Section 5 indicate that substantial savings are possible by lighting retrofits, two-speed compressor and fan retrofits, improved HVAC controls, reflective roof coatings, and economizer cooling.

\subsection{Existing Buildings}

The following conservation measures are recommended for existing office buildings:

- T-8 system lighting retrofit

- improved HVAC controls including weekend setback, heating/cooling arbitration, and optimal-start controls

- two-speed fan retrofit.

\subsection{New Buildings}

Some of the improvements that are attractive in new buildings, such as use of reflective roof materials, can be achieved at virtually no cost when included as part of the new building design specification. Others should be subject to payback analysis by the building designer or design/build team before they are adopted. Based on our analysis the following are recommended:

- New modular buildings should be designed with high-efficiency heat pumps that use variable-speed or two-speed compressors. Utility rebates may be available for this equipment.

- Each new modular building should be equipped with a central controller that provides separate thermostatic control for each unit based on average air temperature at two or three representative points. The controller should also implement night, weekend and holiday setback, optimal start control, and weekend override by unit.

- Small-scale, high-efficiency heat pump-based VAV systems should be considered for new modular buildings; optimal start and enthalpy economizer controls should be included in the HVAC package. Utility rebates may be available for this equipment.

- New modular buildings should be provided with economizer cooling.

- New modular buildings should be designed with reflective roof materials. 
- Water heating by desuperheaters should be considered in new buildings that have significant water heating loads.

- Small-scale district cooling tower loops with diurnal storage should be considered for new modular buildings with water source heat pump-based HVAC systems. Utility rebates may be available for this equipment. 


\subsection{References}

Armstrong, P. R., C. R. Batishko, A. L. Dittmer, D. L. Hadley, J. L. Stoops. 1993a. Mobile Energy Laboratory Procedures. PNL-8838, Pacific Northwest Laboratory, Richland, Washington.

Armstrong, P. R., D. R. Dixon, J. M. Keller, S. A. Shankle, R. R. Wahlstrom, D. B. Elliot, D. J. Stucky. 1993b. Griffiss Air Force Base Integrated Resource Assessment-Volume 3: Electric Resource Assessment. PNL-8545 Vol. 3, Pacific Northwest Laboratory, Richland, Washington.

Armstrong, P. R. 1990. Test Report for Fort Irwin: Measured Lighting Levels in Four Office Buildings. PNL Mobile Energy Laboratory Letter Report IRWIN-003-90/08/01, Pacific Northwest Laboratory, Richland, Washington.

National Institute of Standards and Technology. 1992. Energy Prices and Discount Factors for Life-Cycle Cost Analysis 1993. NIST Handbook 135, NISTIR 85-3273, Gaithersburg, Maryland.

National Bureau of Standards (NBS). 1987. Life-Cycle Costing Manual for the Federal Energy Management Program. NBS Handbook 135, Gaithersburg, Maryland.

Petersen, S. R. January 1992. The NIST "Building Life-Cycle Cost" (BLCC) Program Version 3.2 for 1993) User's Guide and Reference Manual. NISTIR 4481.

Ruegg, R. T. and S. R. Petersen. 1987. Comprehensive Guide for Least-Cost Energy Decisions. NBS Special Publication 709, Gaithersburg, Maryland. 



\title{
Appendix A
}

\author{
MEL Assignment Plan
}



Test Objective: Determine the electric end use profiles of 2 "typical" new modular office buildings. One building will be monitored "as-is." In the second building, the thermostats will be operated with an evening/weekend setback, and possible temporary shut down of some of the heat pumps.

The modular office buildings are equipped with a three-ton heat pump for each $12^{\prime} \times 60^{\prime}\left(720 \mathrm{ft}^{2}\right)$ section and it is suspected there is excess cooling capacity for the combined units. The buildings may be using more electric energy than necessary and contributing significantly to the total electric use for the base. Electric use will also be compared to other office buildings previously monitored in the ELCAP study.

Test Description: Collect time-series electric end use data (heat pump, lighting, convenience outlets) for each office building using PNL commercial FDAS loggers. Indoor and outdoor temperatures will be monitored.

Test Procedure(s): Test Procedure 1 - Building Energy Monitoring

Schedule Requirements: The equipment should be installed in time to monitor energy consumption during the period of maximum demand (July and August). Data should be collected for a minimum of 4 months to account for unusual short-term conditions caused by abnormal weather.

Installation of a single dedicated phone line near the point of installation of each data logger is required for routine data collection.

Cost Estimate: PNL personnel, equipment, and reporting: $\$ 23,400$ to $\$ 27,000$ DEH support: 24 manhours

Approvals:

Richard Szydlowski

MEL Tech Coordinator

John R. Wright

LTC, ENG

Ft. Irwin
Graham Parker

MEL Project Manager

Jim Vasiloff

FORSCOM
Date

Date 

Appendix B

Glossary 


\section{Appendix B}

\section{Glossary}

\section{Terms and Acronyms}
ASHRAE
American Society of Heating, Refrigeration, and Air-Conditioning Engineers
CT
load
baseload
desuperheater
economizer
EMCS
energy-use intensity
(EUI)
end-use
ERO
FEDS
FEMP
heat pump
HVAC
IES
IRP
current transformer-a device which senses alternating current
the power or apparent power required by a building or end-use
constant part of a time-varying electrical load
a heat exchanger used to remove heat from superheated refrigerant that leaves a heat pump compressor and (usually) heat domestic water
a system to cool by use of outside air when conditions permit
Energy Management Control System-describes a variety of general purpose, usually microprocessor-based, HVAC (and other facility) controls annual energy consumption divided by gross floor area
a class of energy using devices that serve a specified function energy resource opportunity-a potential efficiency, conservation or fuel- switching measure
federal energy decision screening-the federal-sector IRP process
Federal Energy Management Program-the umbrella program under which the MEL operates
a refrigeration machine that can operate in reverse to provide heating as well as cooling
heating, ventilating, and air conditioning
Illuminating Engineers Society
integrated resource planning-least cost planning process that considers all energy, conservation, and efficiency resource options 
LCC

MEL

NPV

PV

primary heating (cooling) energy

retrofit

SCE

setback

SIR

source energy

TOU

VAV

VSD

workday life-cycle cost-the PV of owning and operating a facility

Mobile Energy Laboratory

Net Present Value--the difference between the present value (PV) of net savings over the life-cycle cost analysis period and the initial cost of the measure; the PV of net savings is the difference between the sum of PVs of all costs, including energy, to operate and maintain the baseline plant and the sum of PVs of all costs to operate the alternative plant

present value--the value of a series of costs or savings, distributed over time, adjusted for the time-value of money to the present

the energy required to operate a heating (cooling) plant

energy resource option in which equipment is wholly or partly replaced

Southern California Edison--Fort Irwin's electric utility

a change in setpoint that results in lower energy use during unoccupied periods, e.g., a lower heating or higher cooling temperature setpoint

Savings-to-Investment-Ratio--the ratio of first cost to the PV of gross savings where the PV of gross savings equals the first cost plus the NPV

the energy required by a power plant to satisfy a given energy end-use or service

time of use-a type of electric rate structure

variable-air volume--a type of forced air HVAC distribution system

variable-speed drive--a power controller used to modulate motor speed

day when a commercial building is fully occupied, e.g., most weekdays 


\section{Units of Measure}

$\mathbf{A}$

V

kW

kWh

MWh

kVA

Btu

$\mathbf{W} / \mathbf{f t}^{\mathbf{2}}$

$\mathbf{k W h} / \mathrm{ft}^{2}-\mathbf{y r}$

cfm

ton
Ampere (electric current)

Volt (electric potential)

kilowatt (electric power)

kilowatt-hour (electric energy)

megawatt-hour (electric energy)

kilovolt-Ampere (apparent electric power)

British thermal unit (thermal energy)

power density in watts per square foot of floor area

average power density in kilowatt-hours per square foot per year

cubic foot per minute (volumetric flow rate)

A measure of cooling plant capacity equal to $12,000 \mathrm{Btu} / \mathrm{hr}$ 



\section{Appendix C}

\section{SCE Rate Schedule}





\section{Appendix C}

\section{SCE Rate Schedule}

The rate schedule in effect during the monitoring period is shown below. The summer billing period for Southern California Edison (SCE) runs from the first Sunday in June to the first Sunday in October. This period will be 17 weeks long in 4 of every 7 years and 18 weeks long in 3 of every 7 years. The average number of working days in the summer billing period is therefore:

$$
(4 * 17+3 * 18) * 5 / 7-2=85.14
$$

and the average number of working days in the winter billing period is:

$$
252.89-85.14=167.75
$$

Rates and times for SCE's time-of-use (TOU) billing periods are summarized below:

\begin{tabular}{||l|r|r|r|r||}
\hline $\begin{array}{l}\text { SCE TOU Billing } \\
\text { Period }\end{array}$ & $\begin{array}{r}\text { Ft. Irwin } \\
\text { Office Hr }\end{array}$ & Hours & $\$ / \mathrm{kW}$ & $\$ / \mathrm{kW}$ \\
\hline $\begin{array}{l}\text { Summer On-Peak } \\
12: 00-1800\end{array}$ & $12: 00-17: 00$ & 5.0 & .10216 & 14.15 \\
\hline $\begin{array}{l}\text { Winter On-Peak } \\
\text { 12:00-18:00 }\end{array}$ & $8: 00-12: 00$ & 4.0 & .08268 & 2.15 \\
\hline $\begin{array}{l}\text { Winter Mid-Peak } \\
8: 00-12: 00 \\
\text { Off-Peak }\end{array}$ & $12: 00-17: 00$ & 5.0 & .09288 & 2.15 \\
\hline
\end{tabular}

The annual direct cost per baseload $\mathrm{kW}$ is therefore:

\begin{tabular}{||c|c|c|c|c|c||}
\hline Days & hr/day & $\$ / \mathrm{kWh}$ & Mos. & $\$ / \mathrm{kW}$ & $\$ / \mathrm{kWb}$ \\
\hline 85.14 & $* 5.0 *$ & .10216 & $+4 *$ & 14.15 & $=100.09$ \\
\hline 85.14 & $* 4.0 *$ & .08268 & $+4 *$ & 2.15 & $=36.43$ \\
\hline 167.75 & $* 5.0 *$ & .09288 & $+8 *$ & 2.15 & $=95.10$ \\
\hline 167.75 & $* 4.0 *$ & .09288 & $+8 *$ & 2.15 & $=79.52$ \\
\hline 252.89 & $* 0.5 *$ & .05012 & $+12 *$ & 2.15 & $=32.14$ \\
\hline & & & & & 343.29 \\
\hline
\end{tabular}


The additional cost for cooling at a coefficient of performance (COP) of 2.5 is $(100.09+(4+8+8+12)$ * $2.15) / 2.5=\$ 67.56 / \mathrm{yr}$. This gives a total energy cost of $\$ 410.84 / \mathrm{yr}$ per baseload lighting $\mathrm{kW}$.

The on-peak demand charge is $\$ 14.15$ per $\mathrm{kW}$ per month during the four summer months. There is an additional savings of $1 / 2.5 \mathrm{~kW}$ in cooling demand for every $1 \mathrm{~kW}$ of avoided lighting load. The annual savings per $\mathrm{kW}$ of avoided on-peak summer lighting load is therefore:

$$
\$ 14.15 * 4 *(1+1 / 2.5)=\$ 79.24
$$

The on-peak demand charge is $\$ 2.15$ per $\mathrm{kW}$ per month during the eight winter months. There is an additional savings of $1 / 2.5 \mathrm{~kW}$ in cooling demand for every $1 \mathrm{~kW}$ in lighting load. The annual savings per $\mathrm{kW}$ of avoided on-peak winter lighting load is therefore:

$$
\$ 2.15 * 8 *(1+1 / 2.5)=\$ 24.08
$$




\section{Appendix D}

\section{Additional Data}





\section{Appendix D}

\section{Additional Data}

Weekly data plots from December 1989 and January, February, March 1990 are presented in this appendix.

The first set of plots, pages D.2 through D.14, shows load histories for five end-uses monitored in Building 567. The load histories for lights, plugs, and mixed circuits are shown in the upper figure on each page. The aggregate electric loads for heat pumps operating in the cooling mode and the aggregate electric loads for heat pumps operating in the heating mode are shown in the lower figure on each page.

Heating and cooling demand distributions for Building 567 are shown in the second set of plots, pages D.15 through D.27. The lower figure on each page shows the distribution of demand obtained by taking the average of 15-minute demands over all eight heat pump units.

Indoor air temperature histories are shown in the third set of plots, pages D.28 through D.35. The upper figure on each page shows the five room temperatures measured in Building 567. The lower figure on each page shows the four room temperatures measured in Building 571.

Additional temperature histories are shown in the fourth set of plots, pages D.36 through D.43. The upper figure on each page shows the average of five room temperatures in Building 567, the average of four room temperatures from Building 571, and outdoor temperature measured at Building 567 (measured outside the north wall just below the roofline). The lower figure on each page shows two additional temperature histories. The outdoor temperature measured by a shielded thermistor outside of Building 571 closely tracks the outdoor temperature measured outside of Building 567. The jagged line that alternately rises above and falls below the average Building 567 room temperature is the average of eight supply air temperatures measured in Building 567.

The last page, D.44, shows average-day heat pump and non-heat pump loads in the two buildings for late December 1989 through early March 1990. The upper plot is for weekdays and the lower plot is for weekends. 

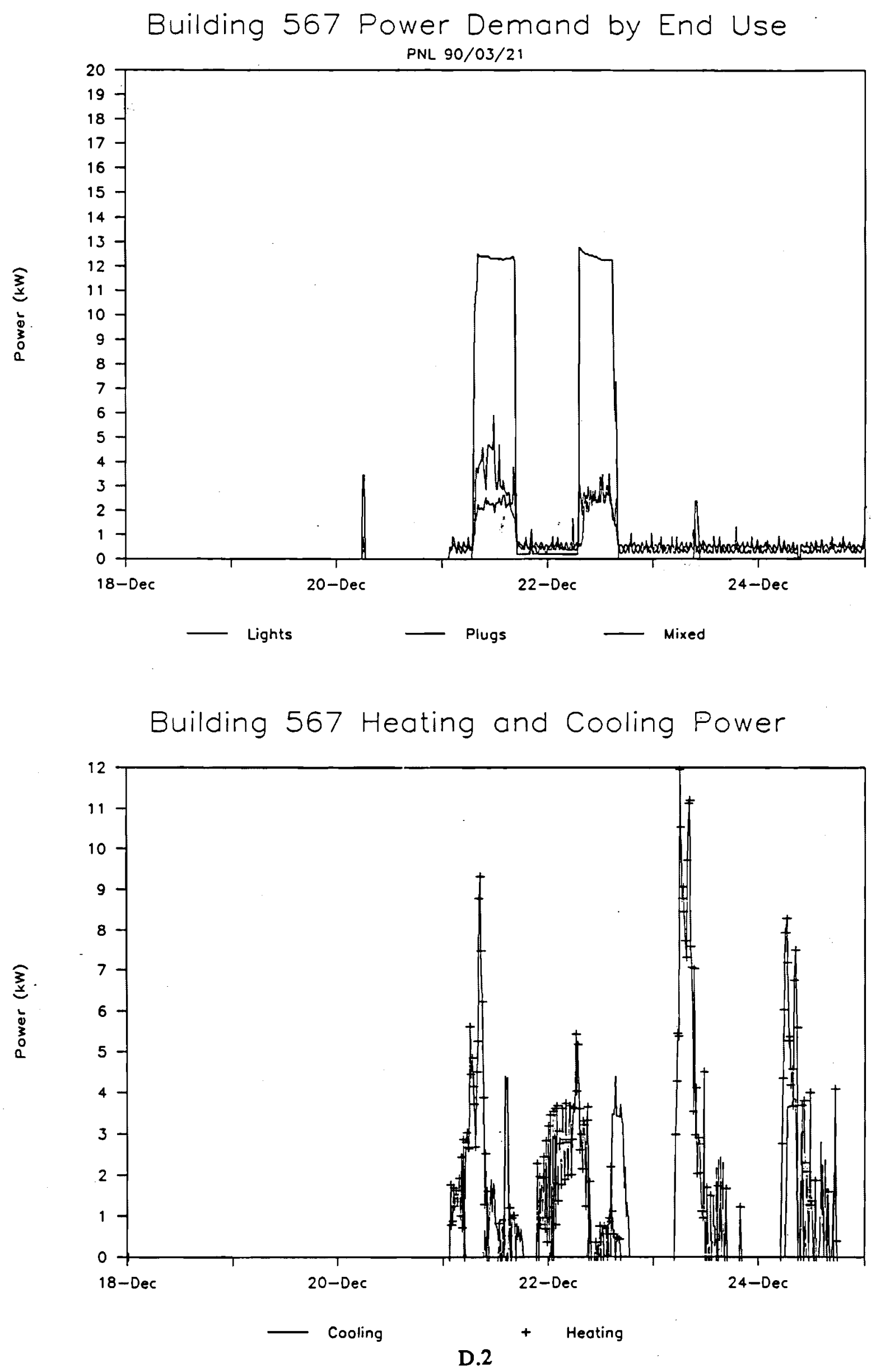
Building 567 Power Demand by End Use

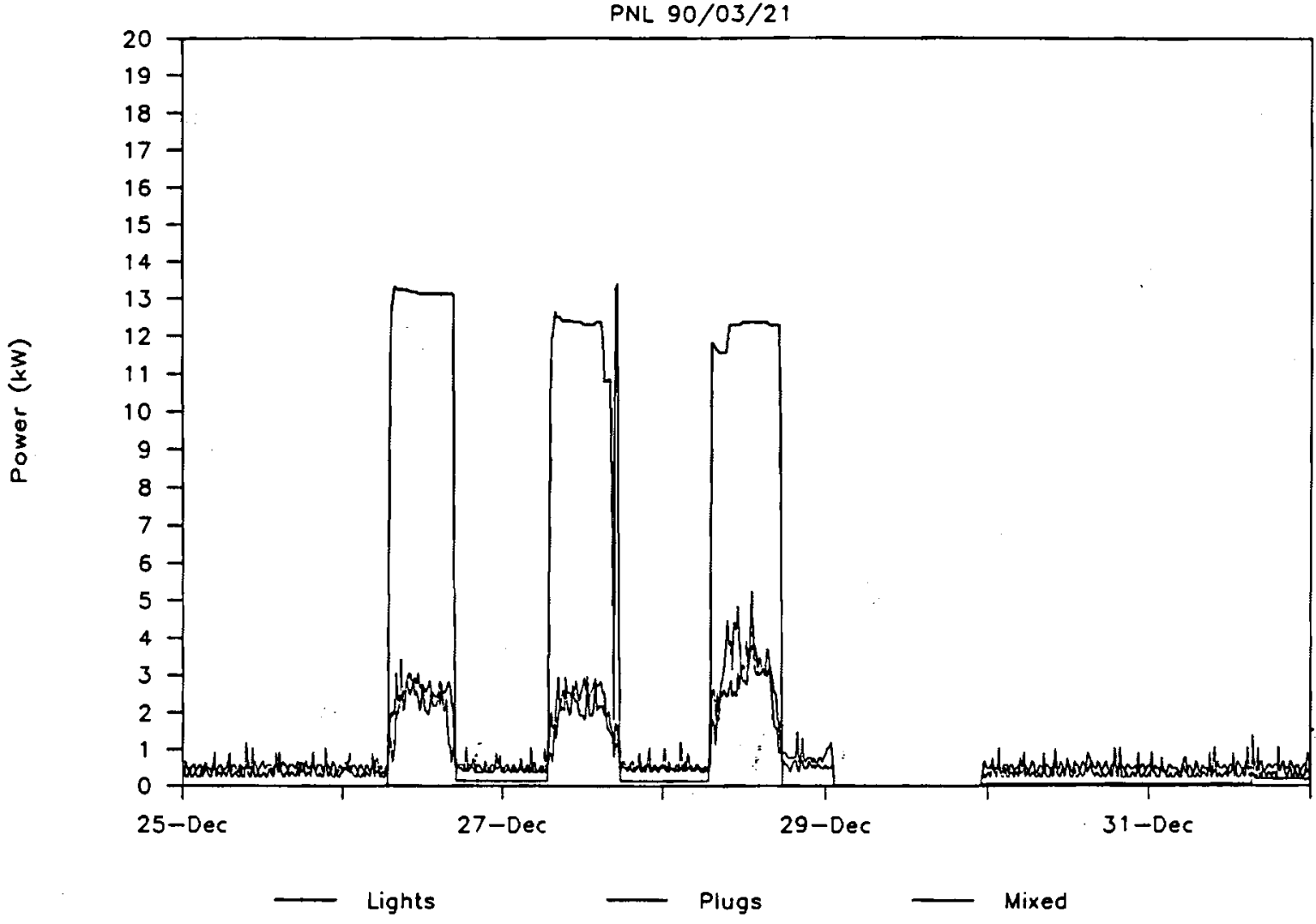

Building 567 Heating and Cooling Power

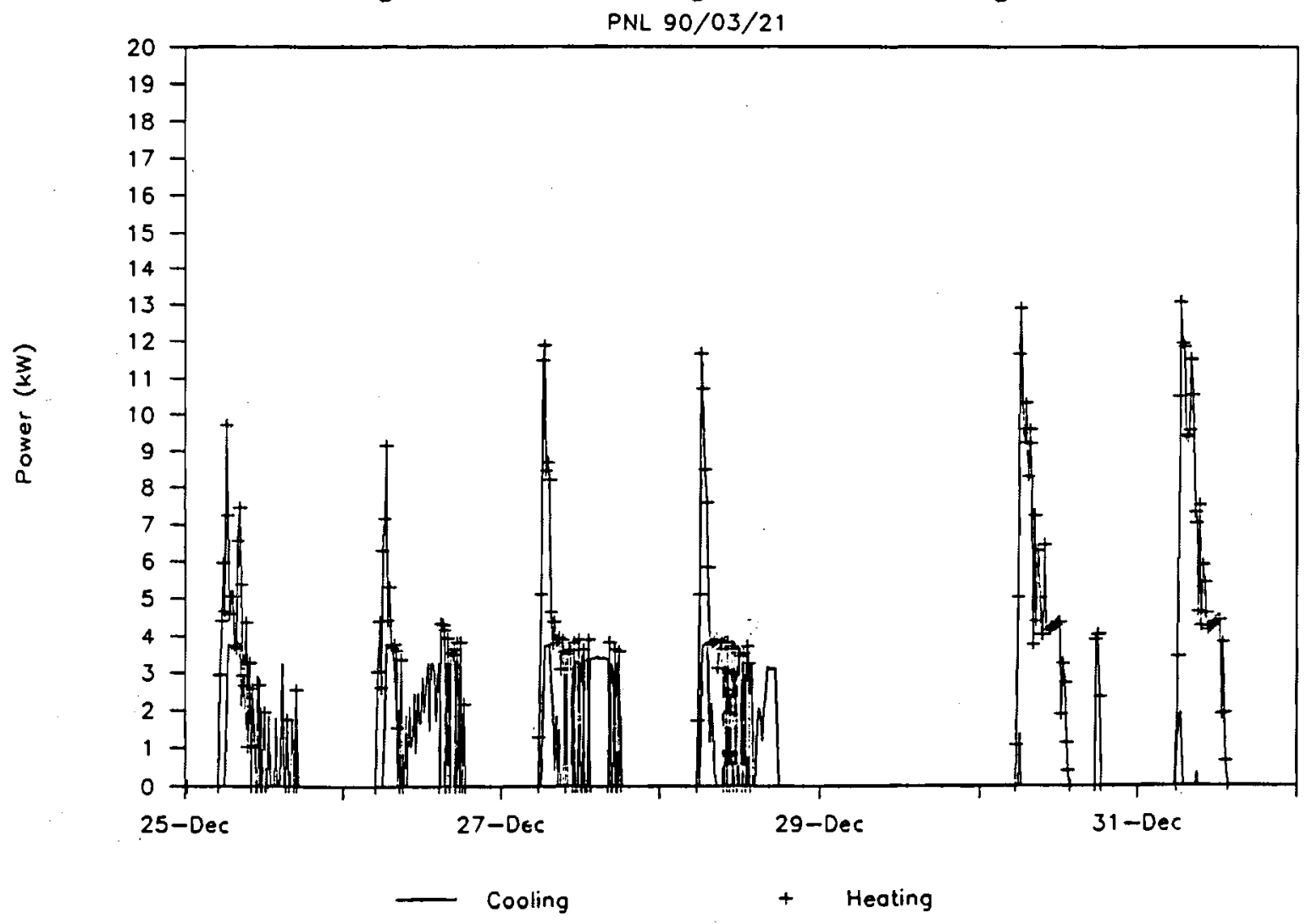

D.3 
Building 567 Power Demand by End Use PNL 90/03/21

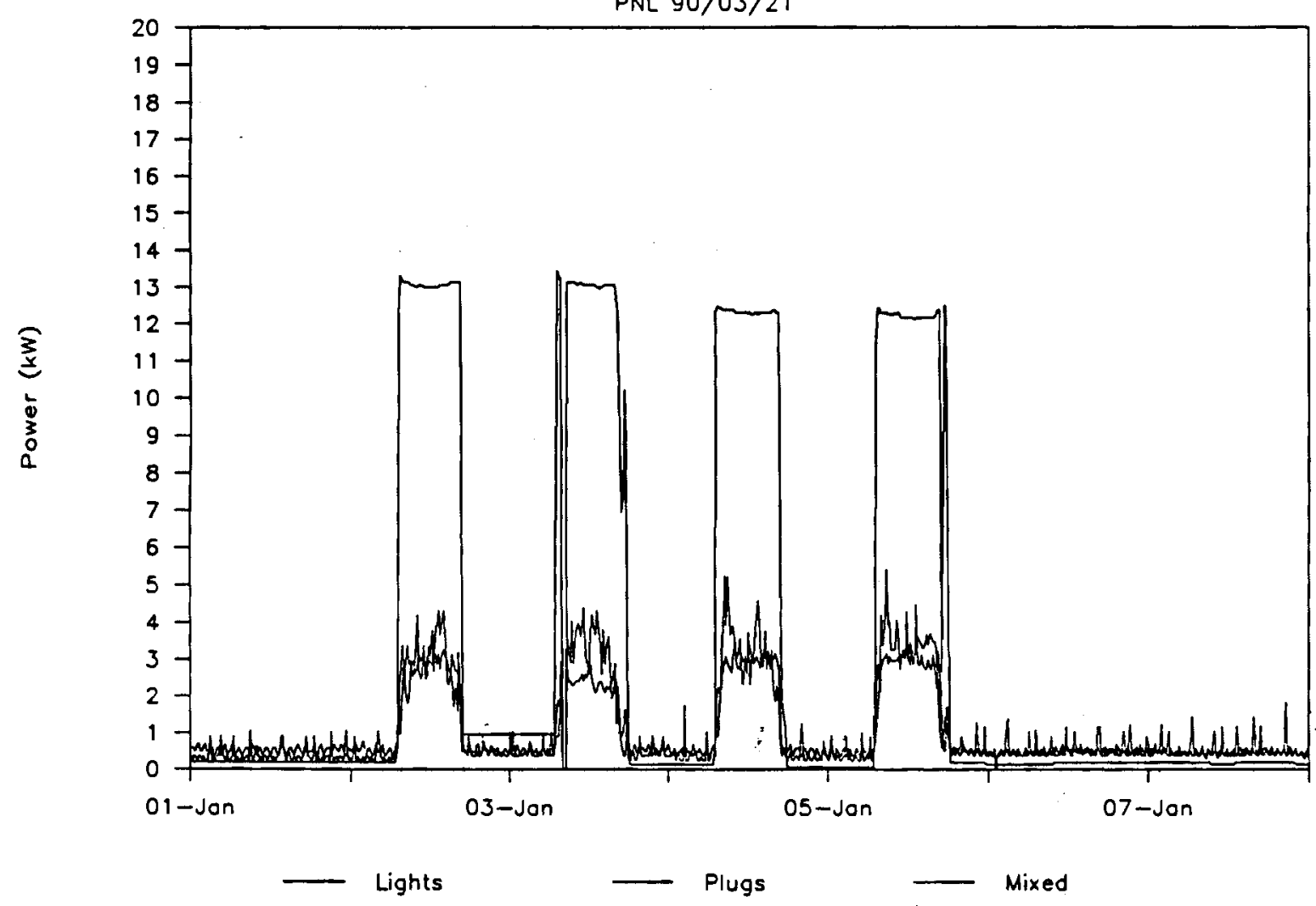

Building 567 Heating and Cooling Power

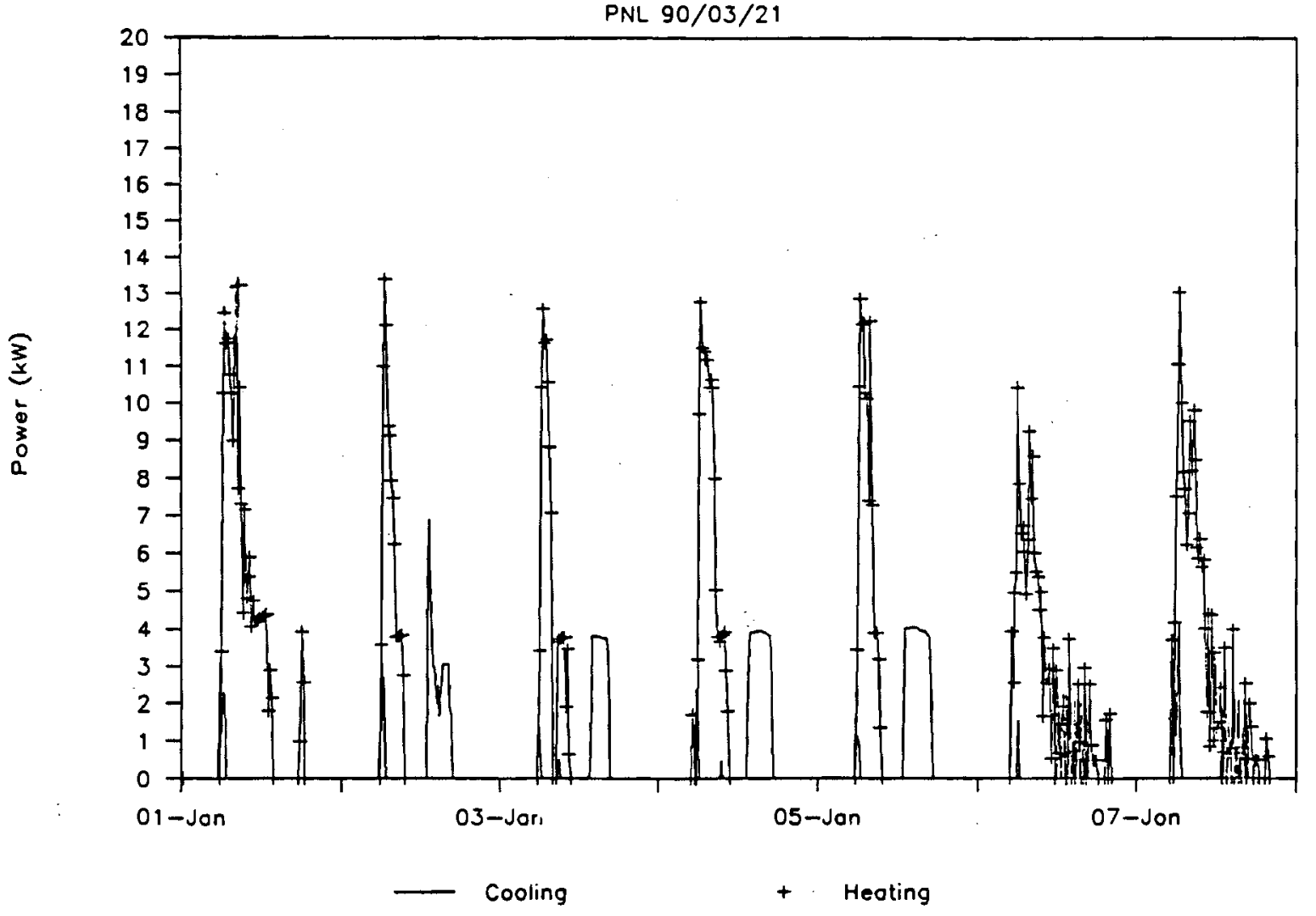

D.4 


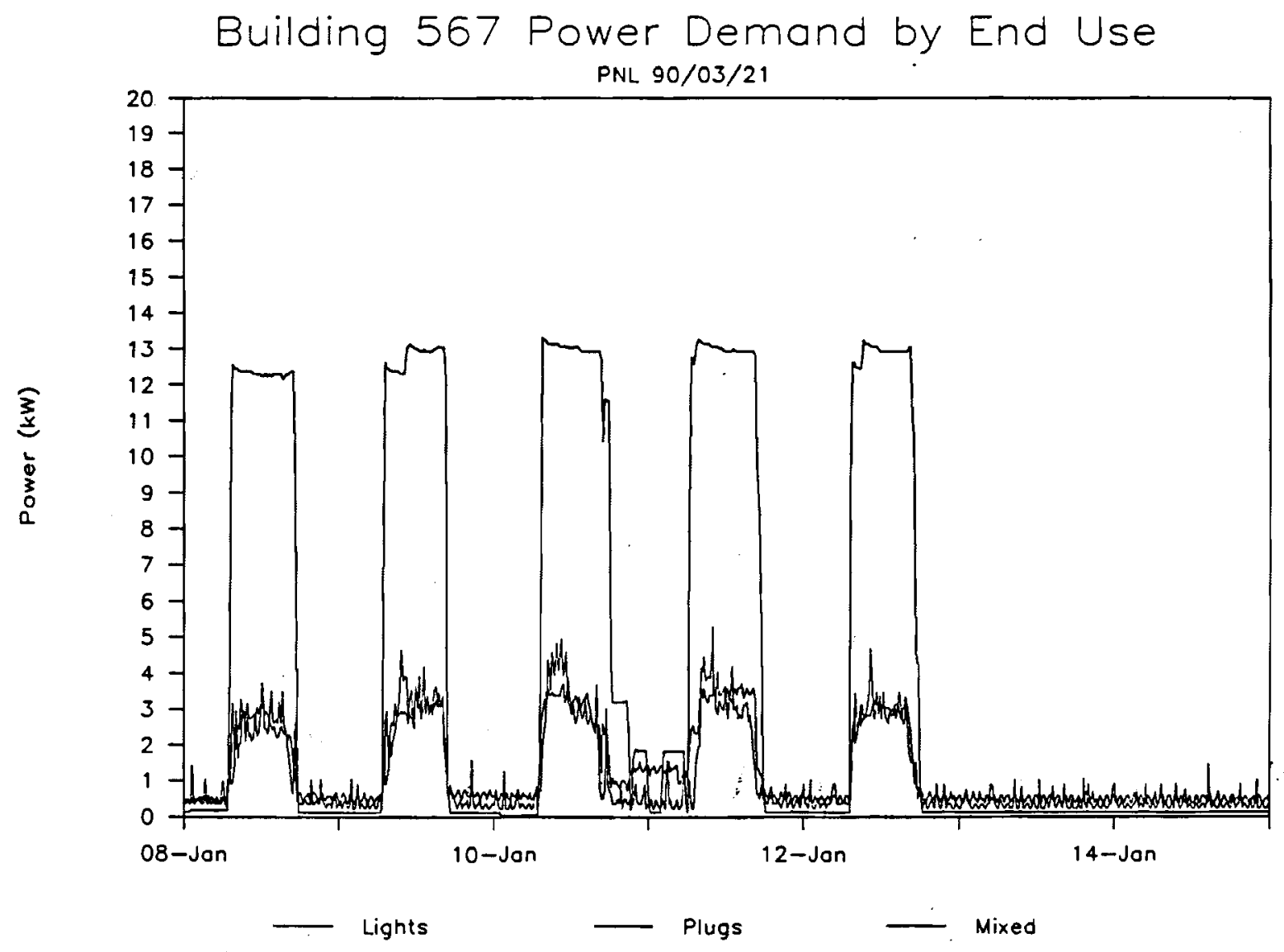

Building 567 Heating and Cooling Power

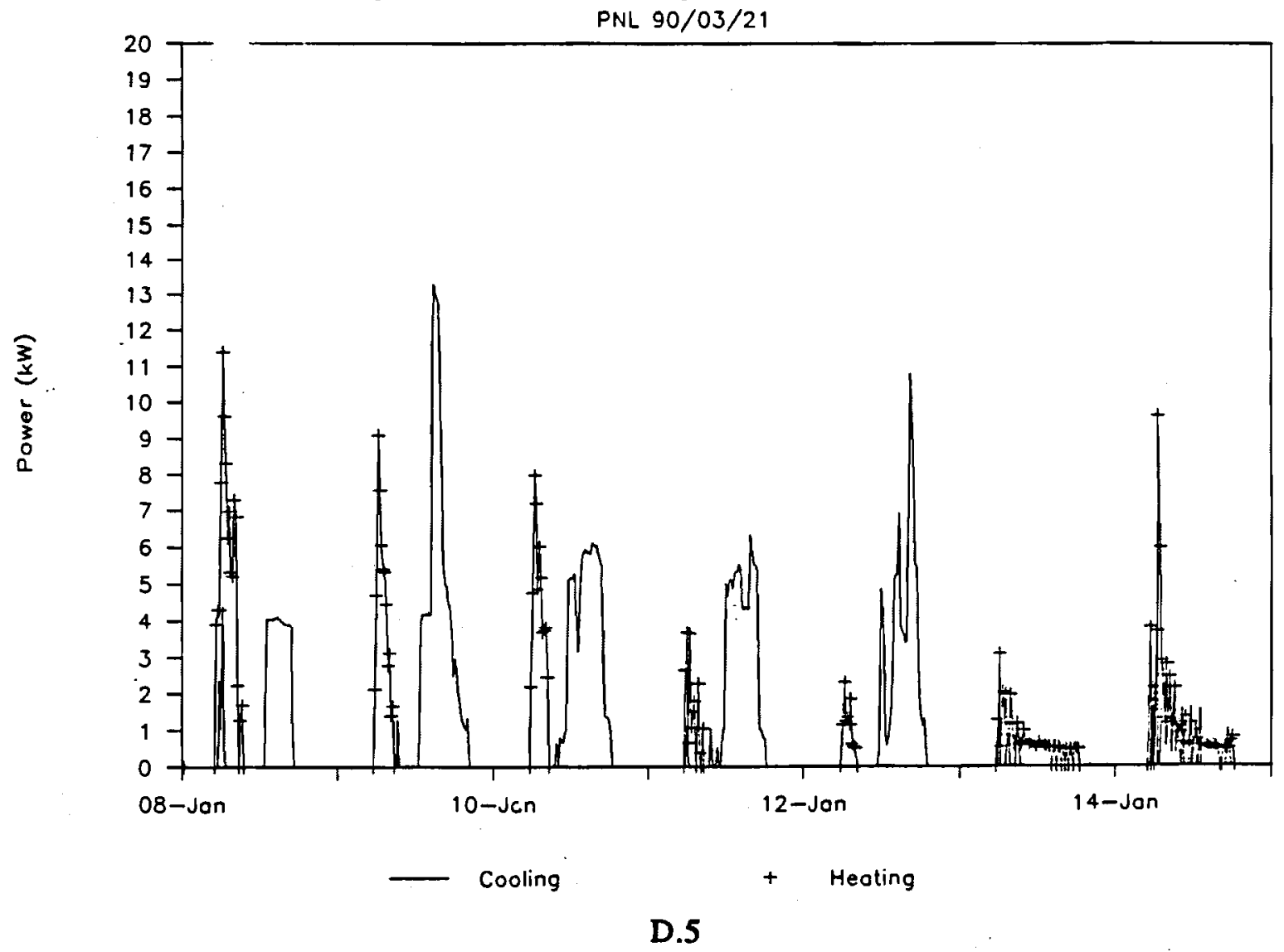




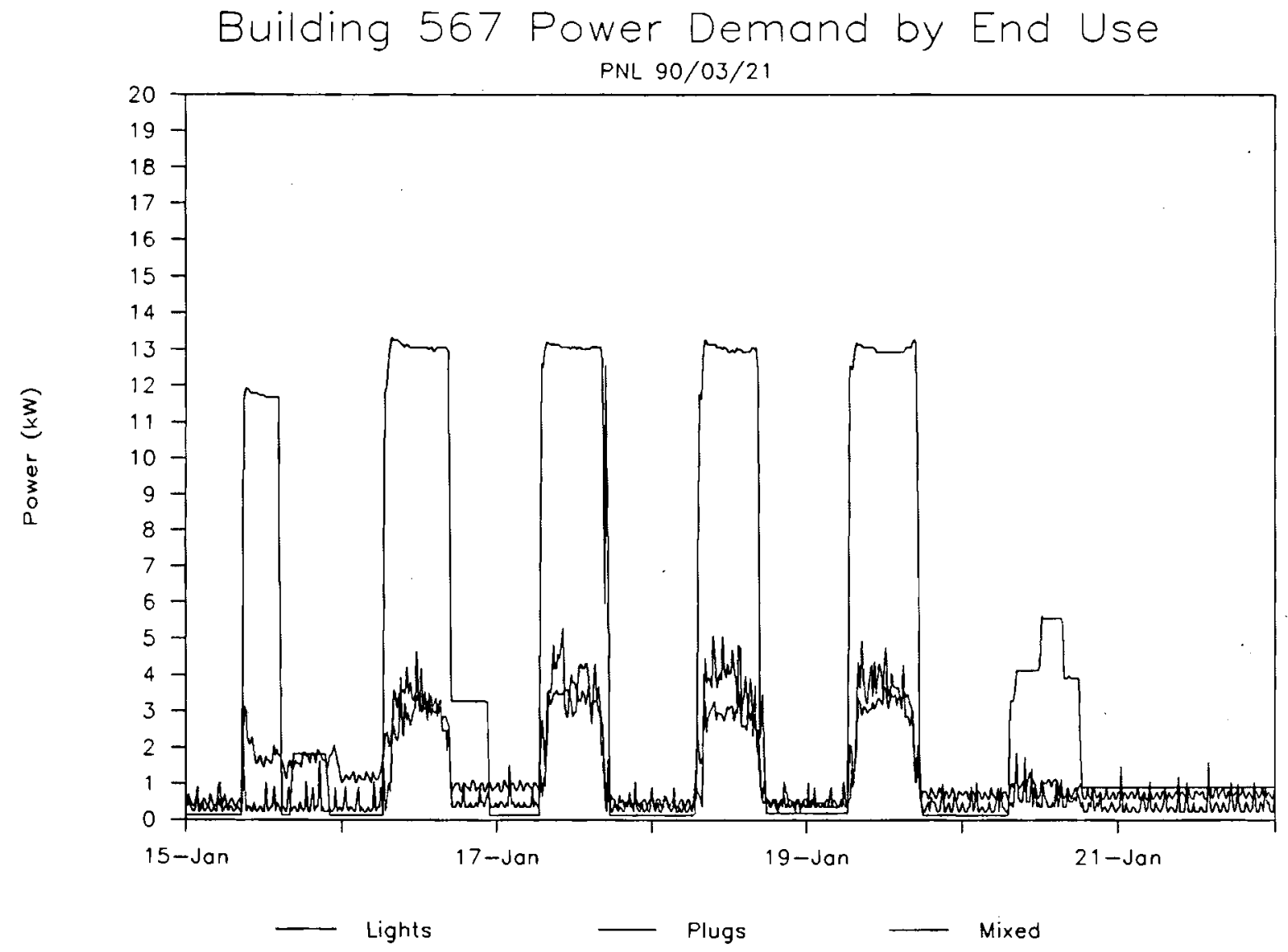

Building 567 Heating and Cooling Power

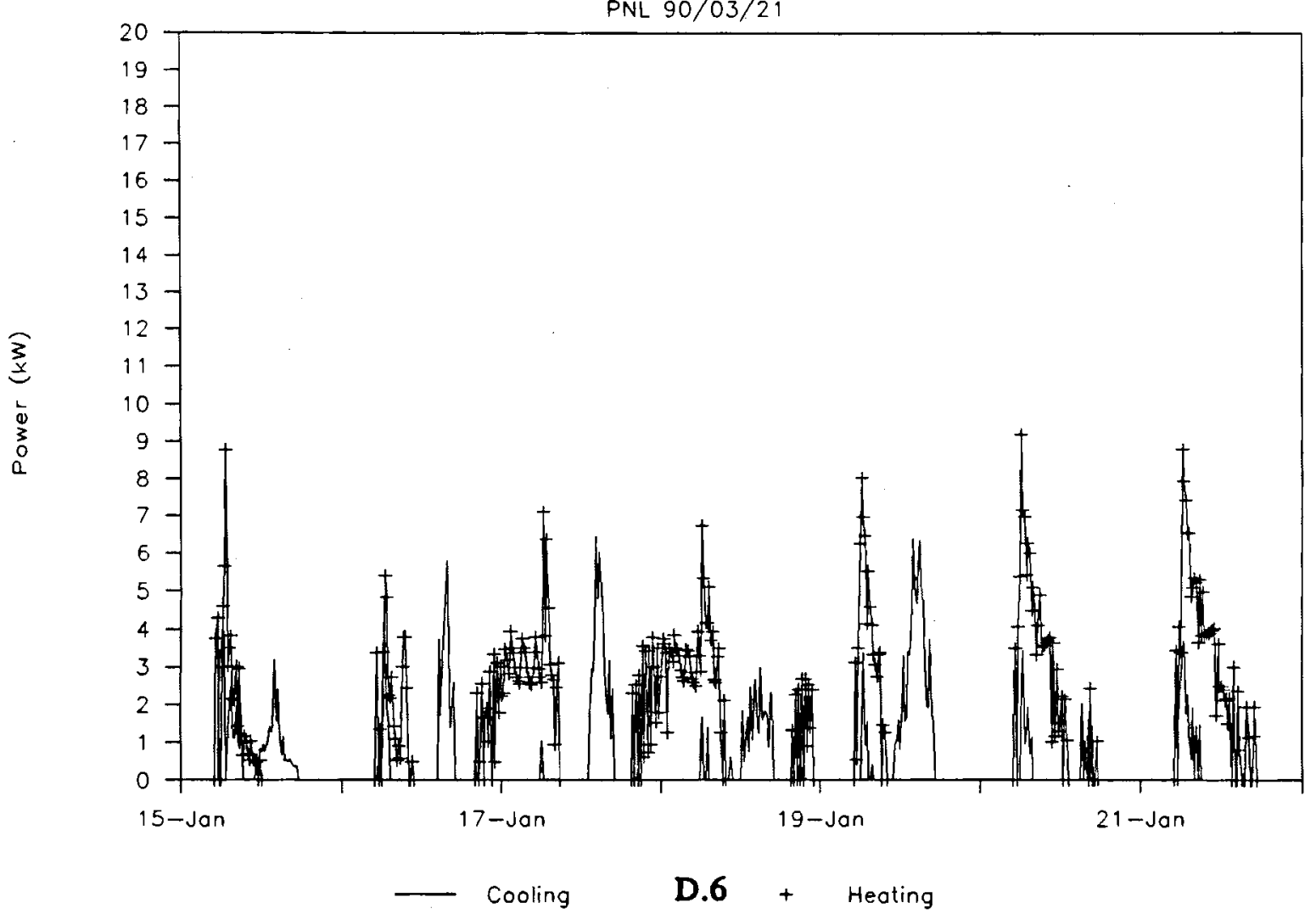



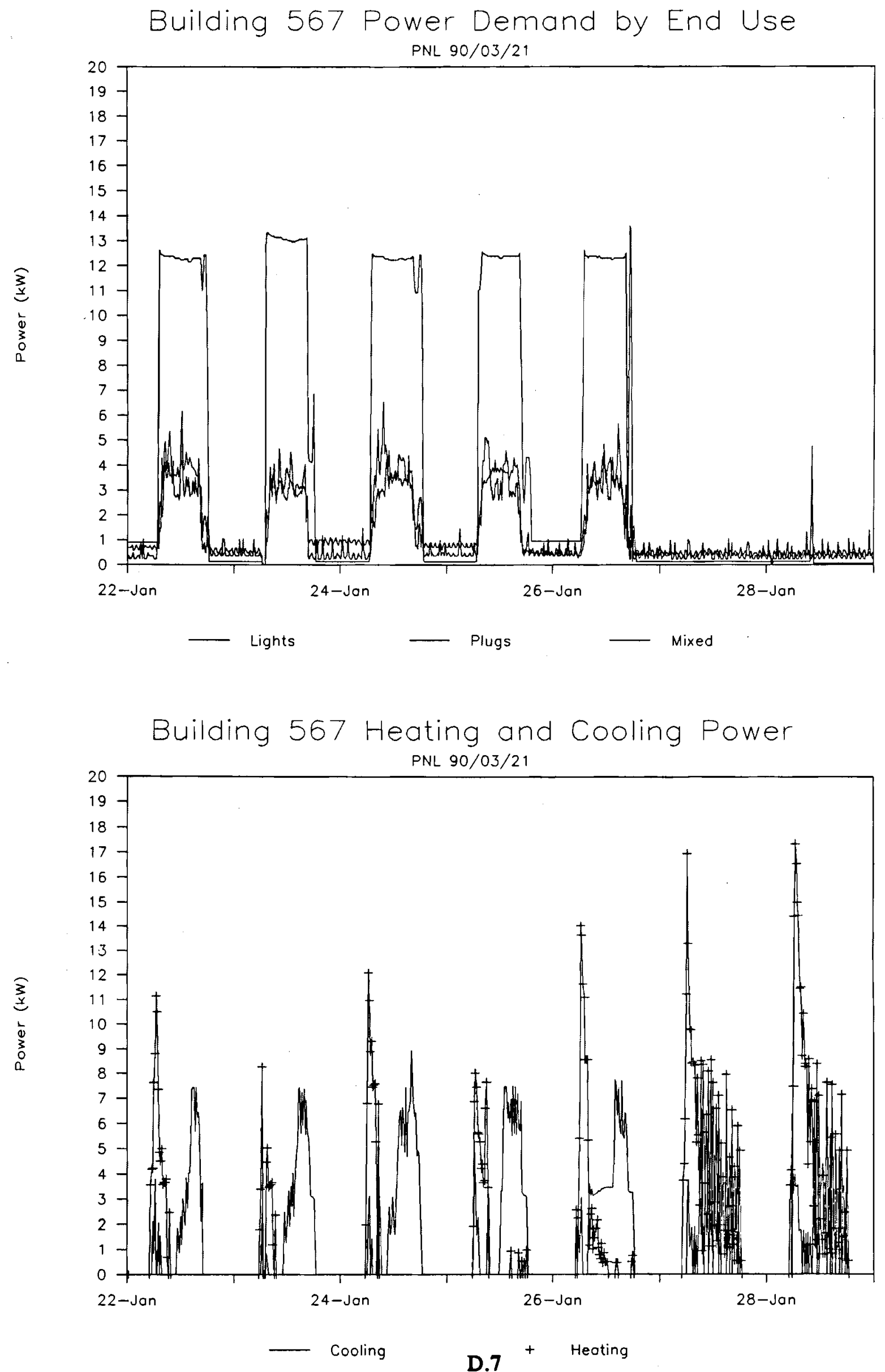

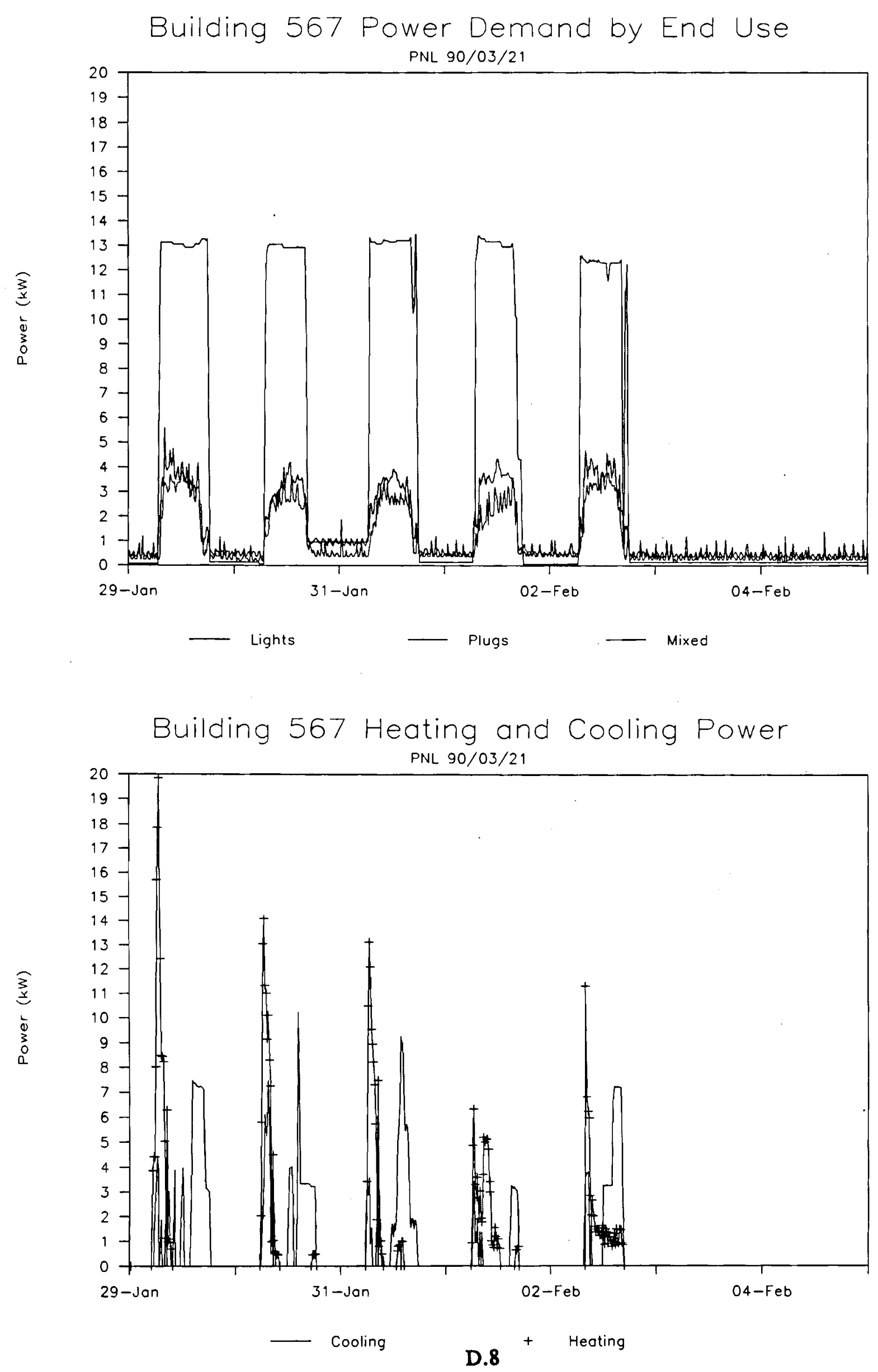

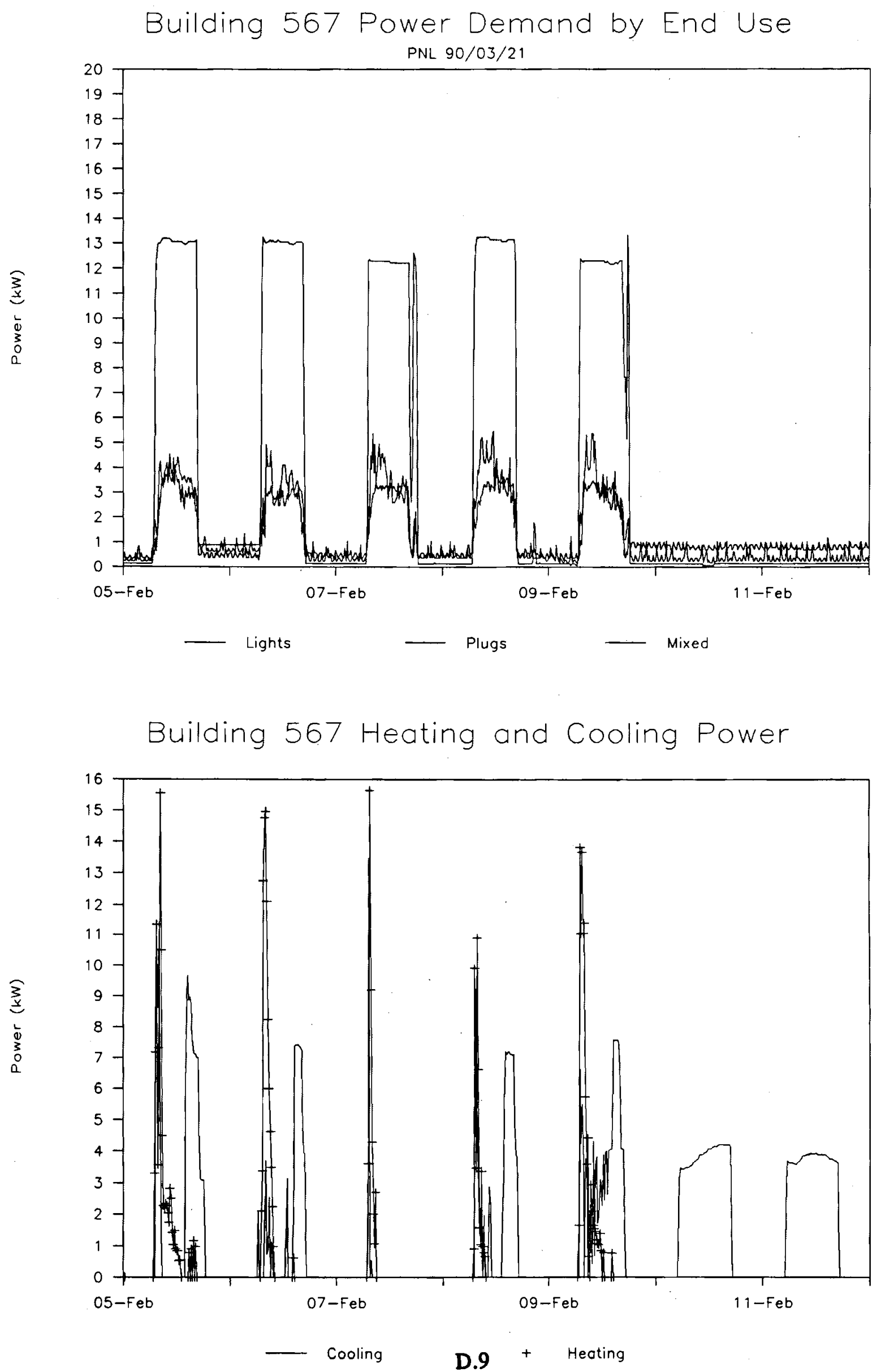

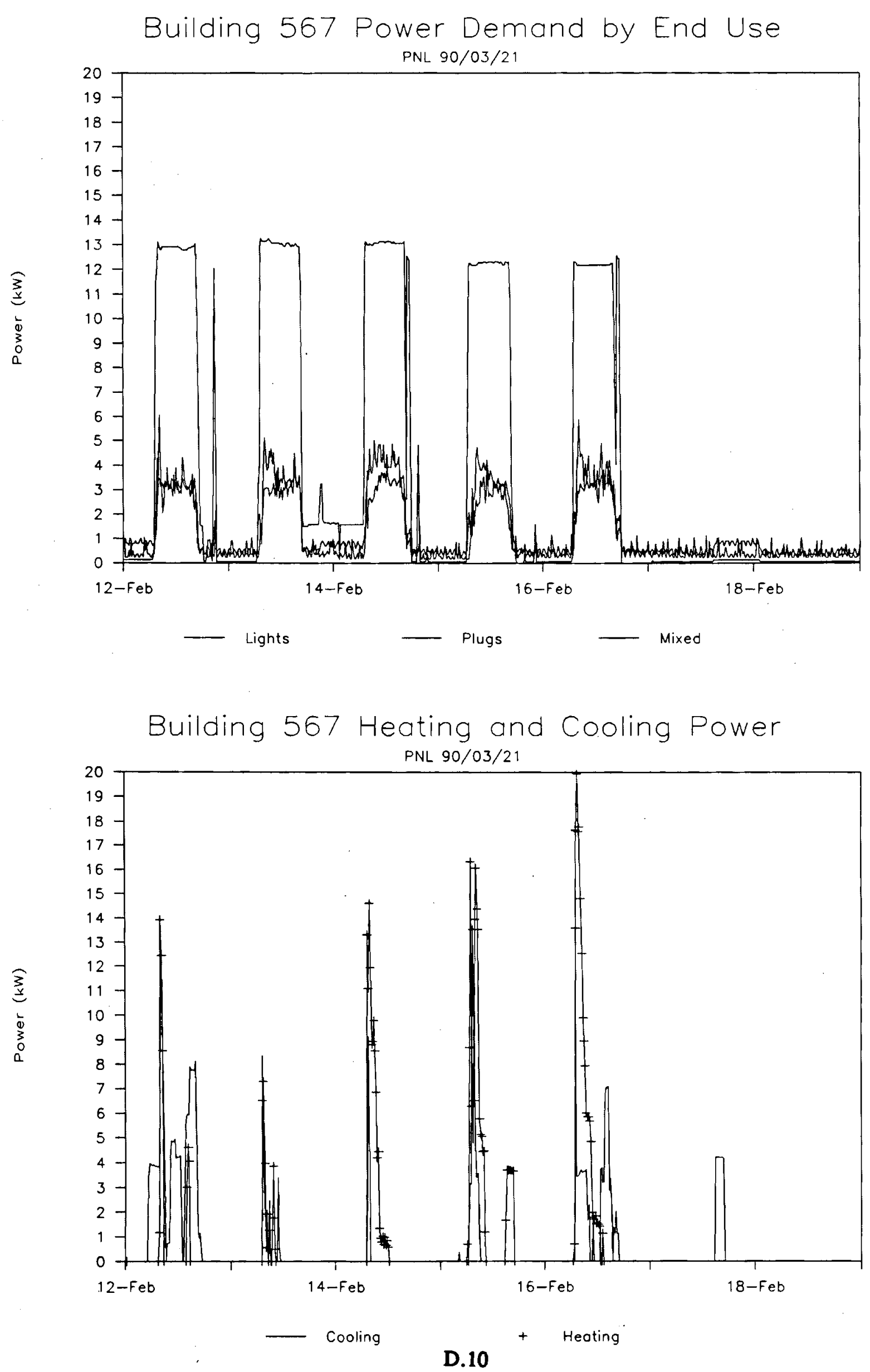

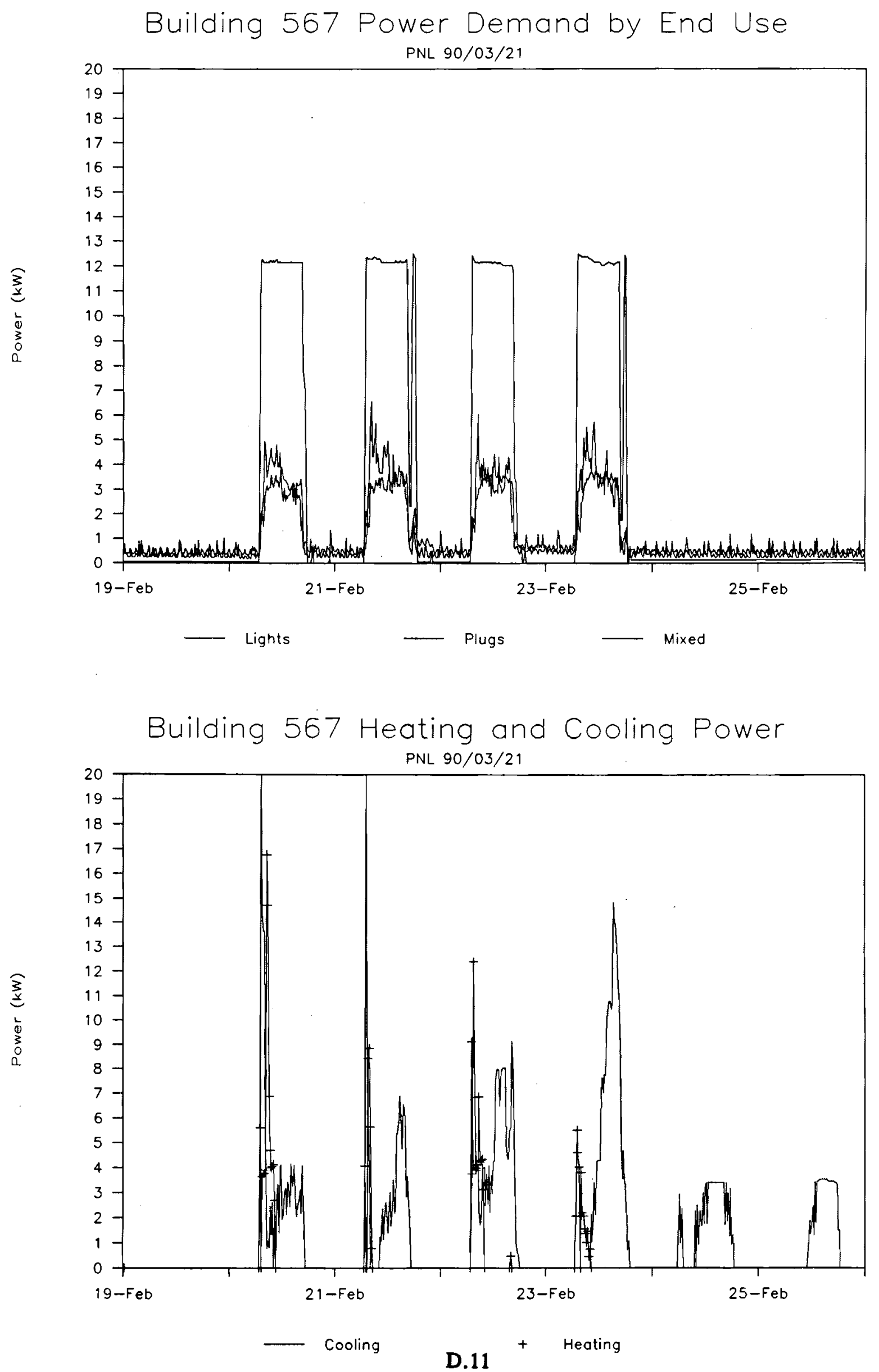
Building 567 Power Demand by End Use

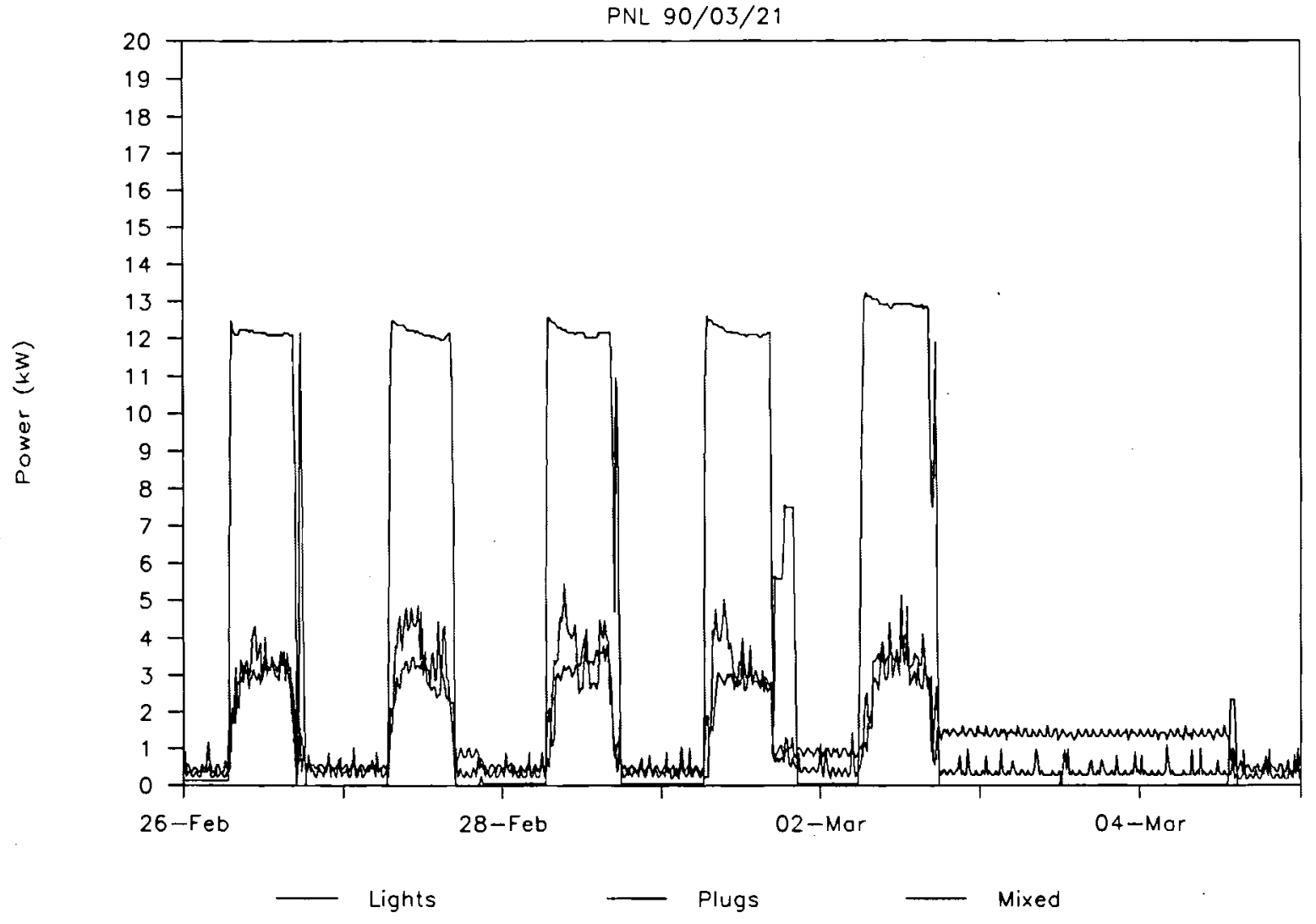

Building 567 Heating and Cooling Power

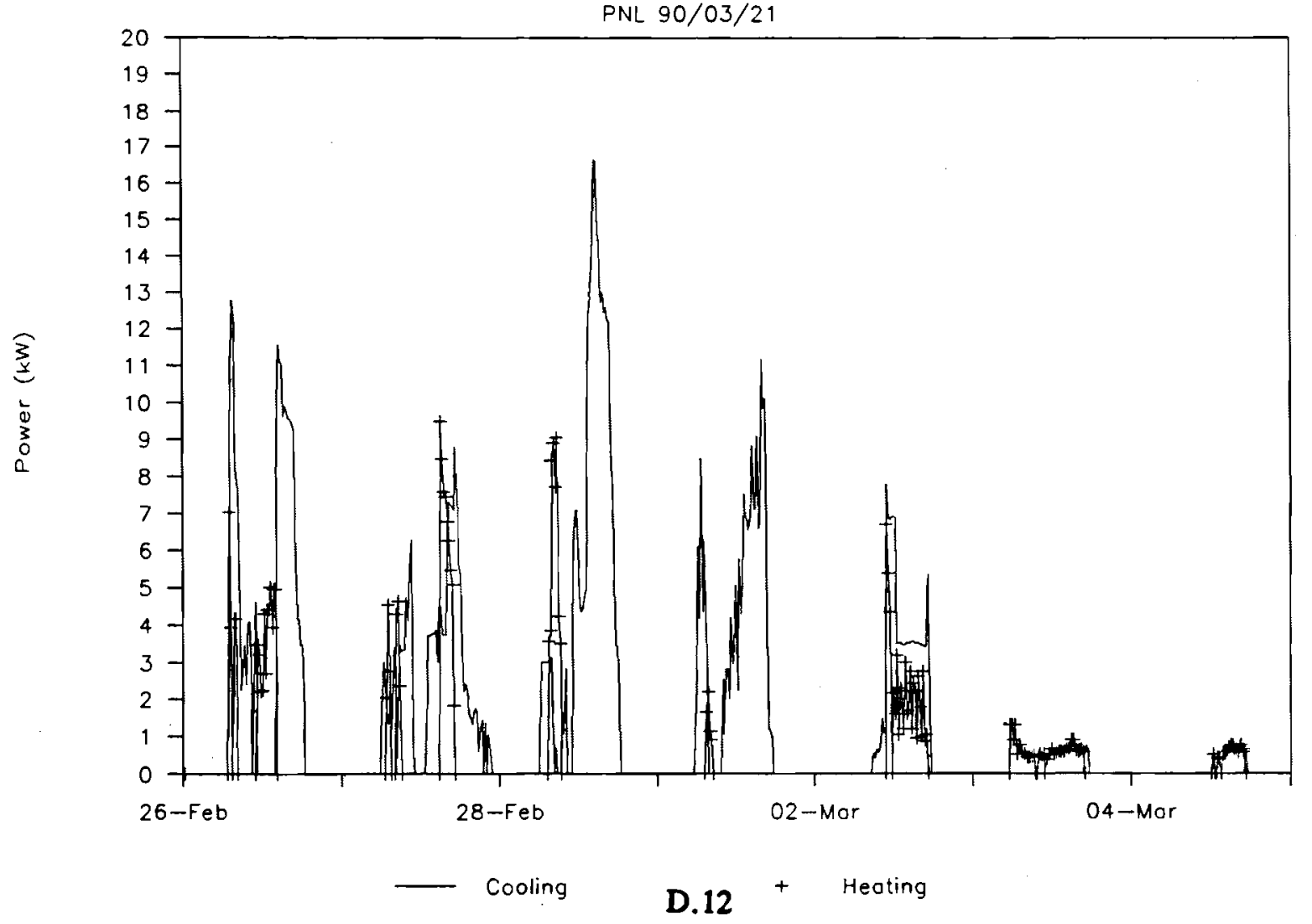



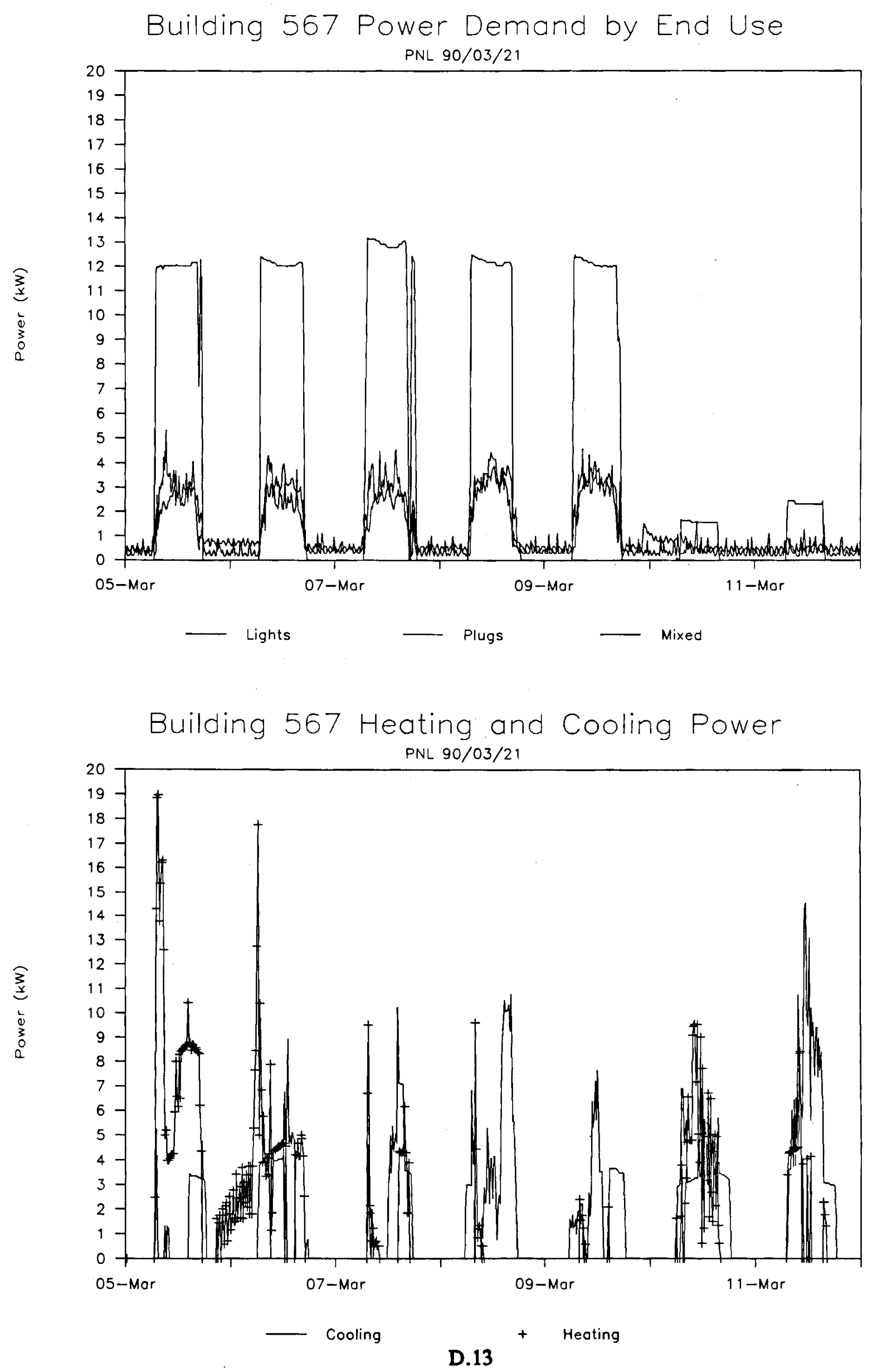

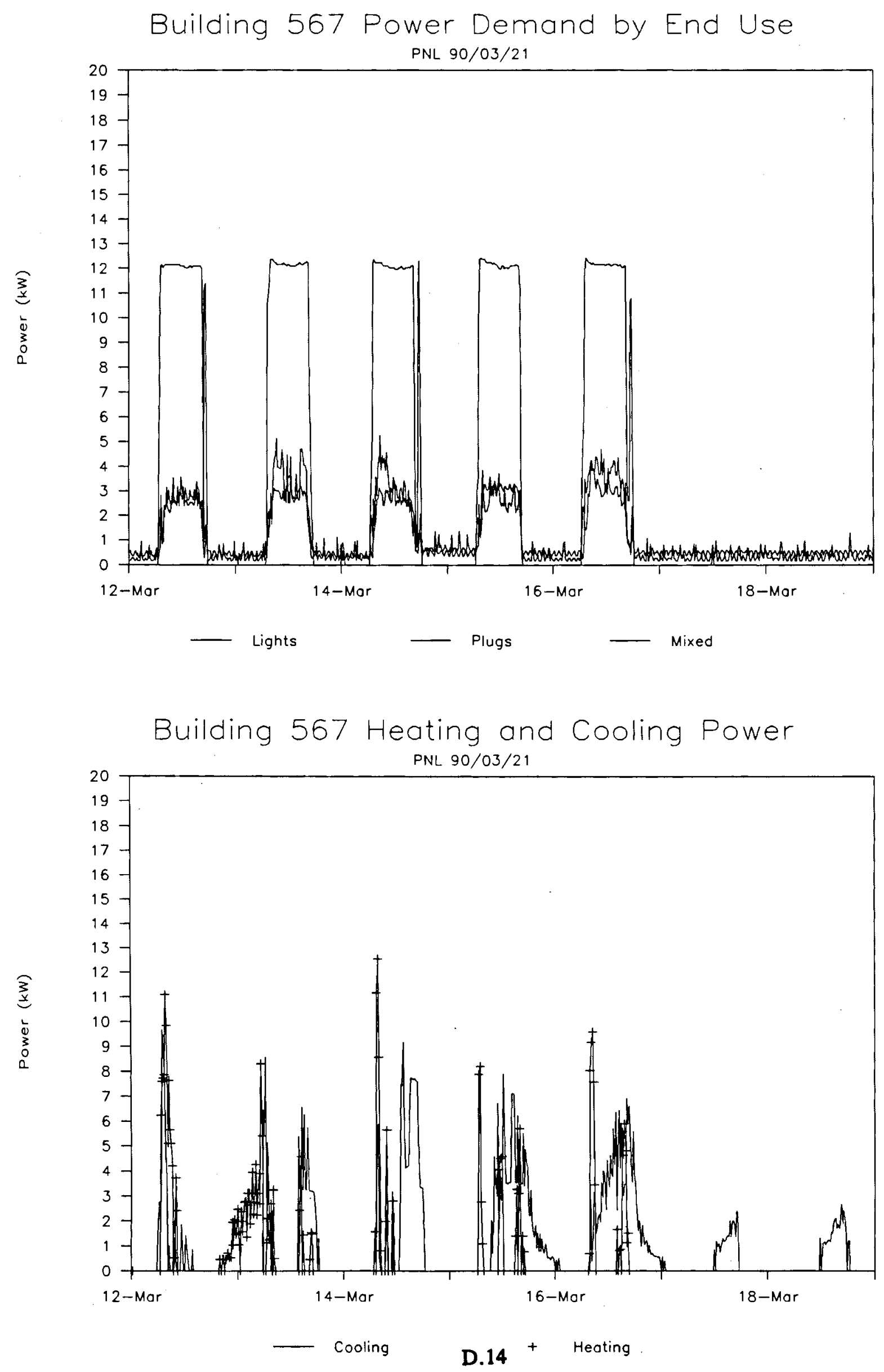

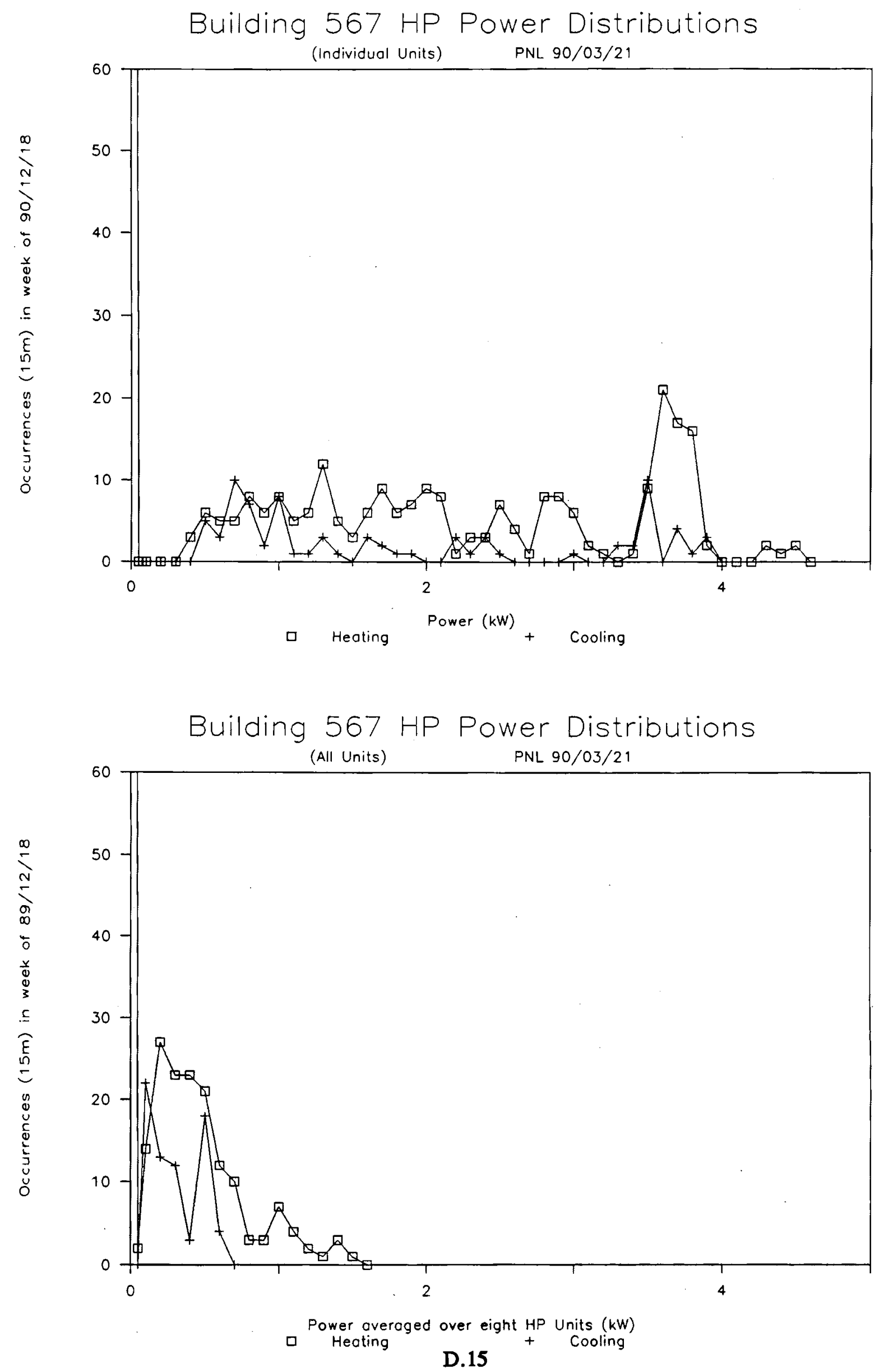

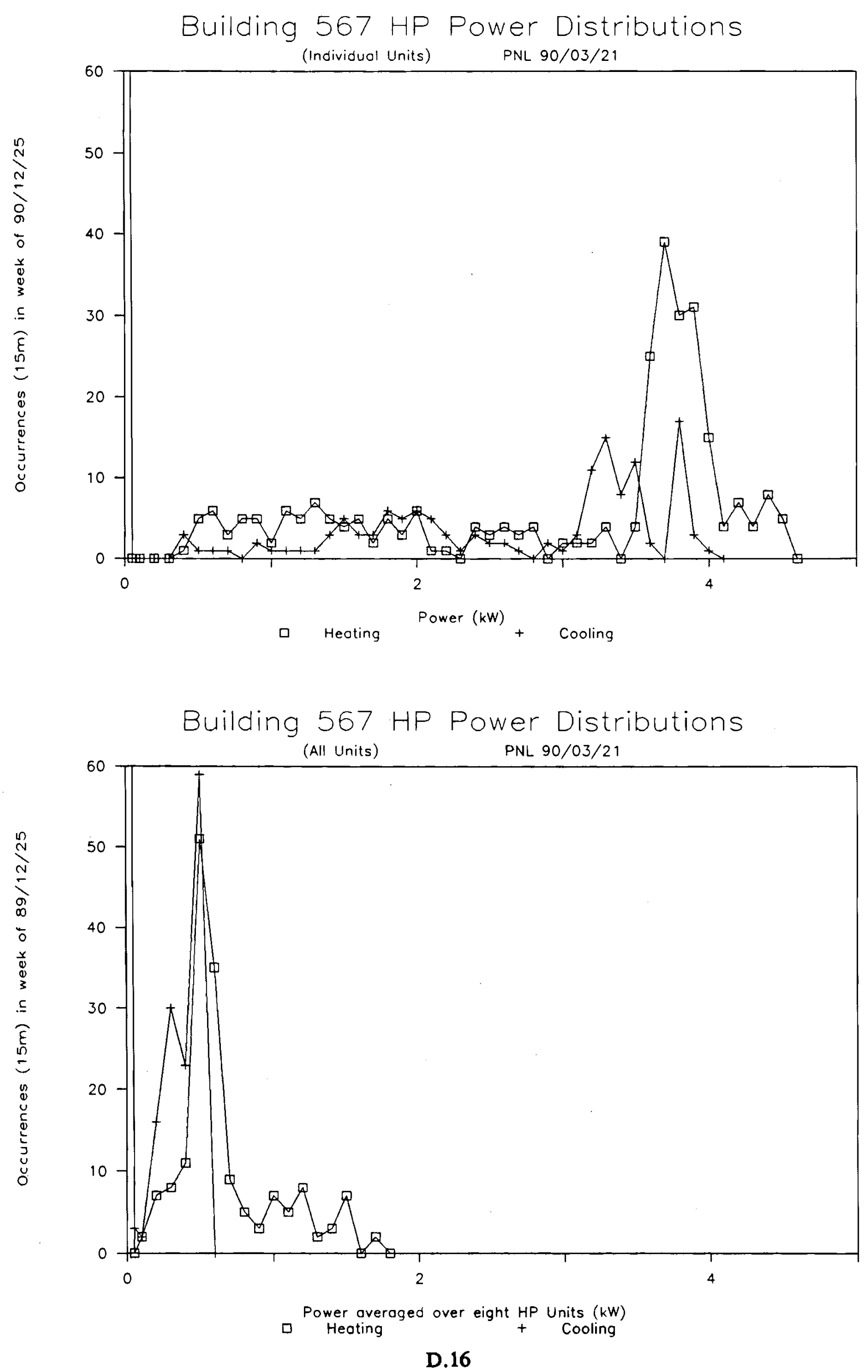

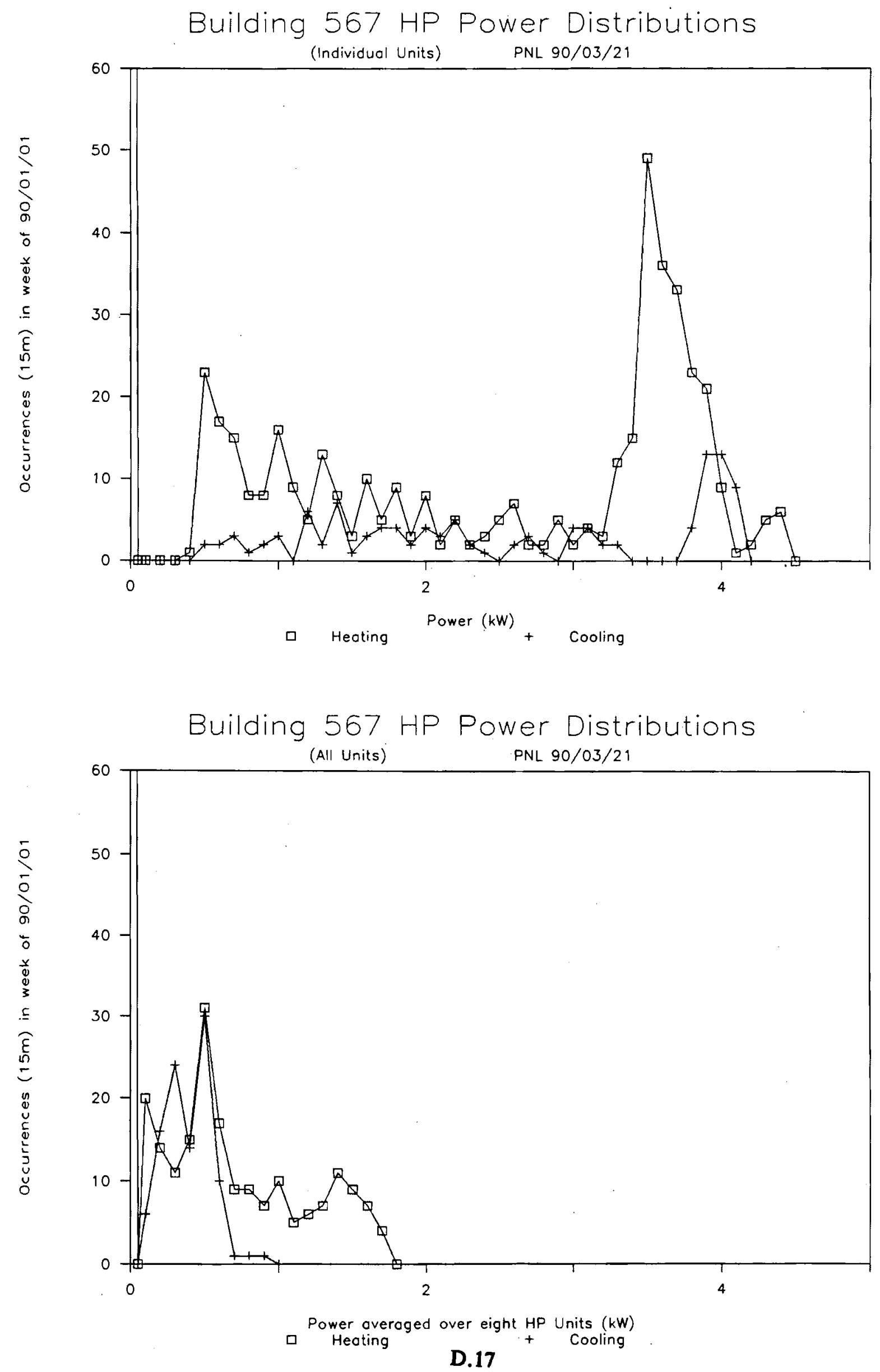

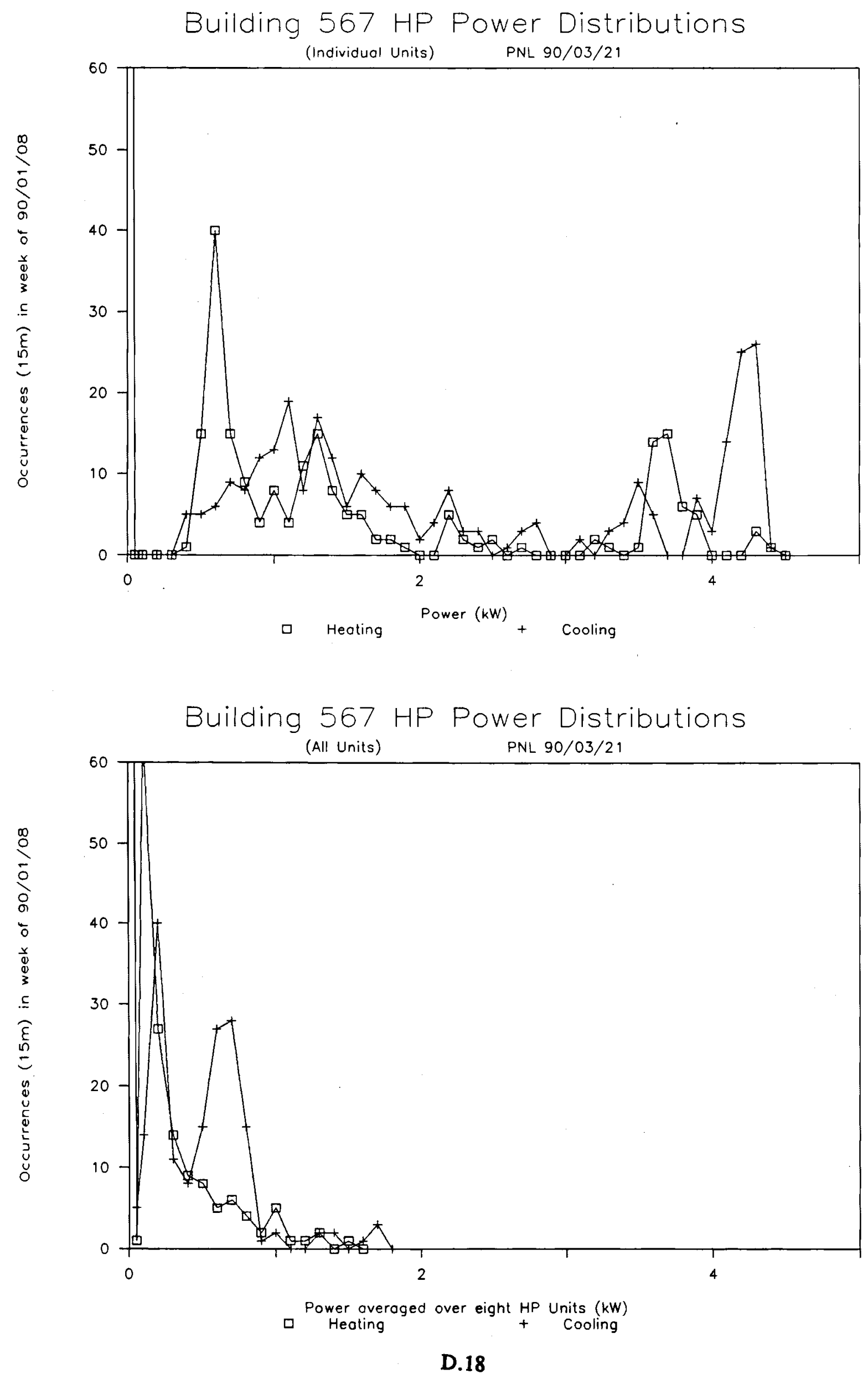


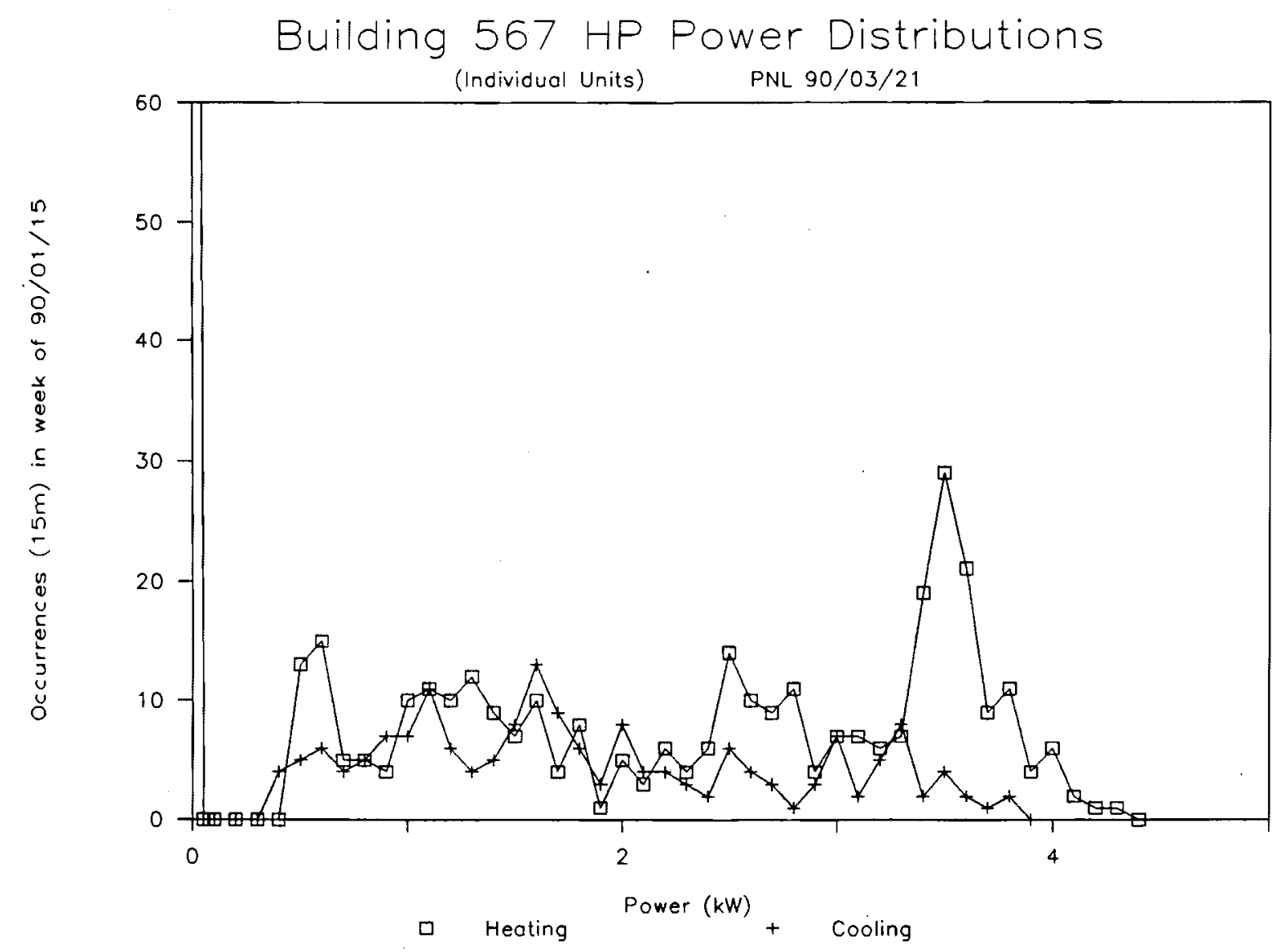

Building 567 HP Power Distributions

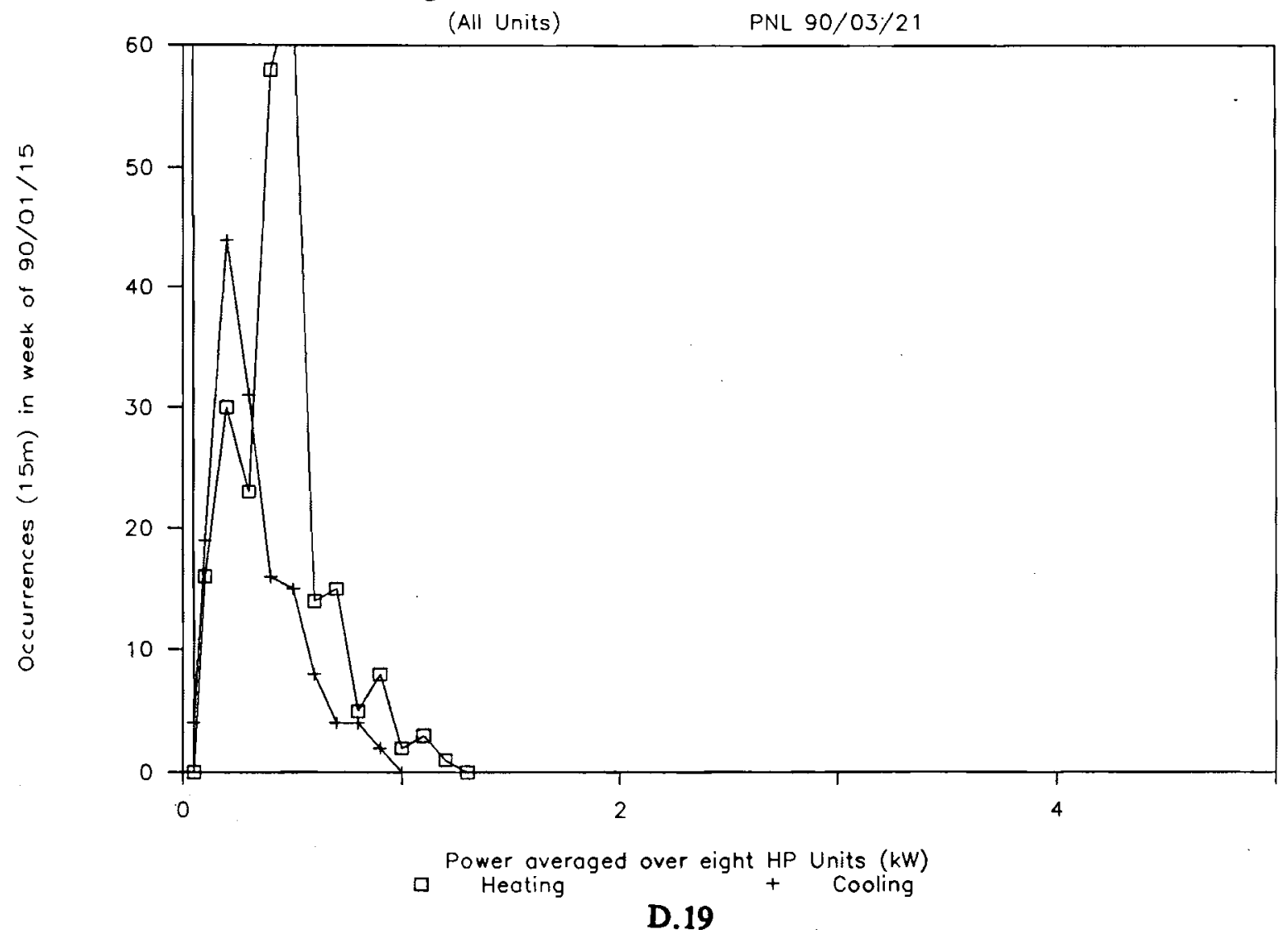




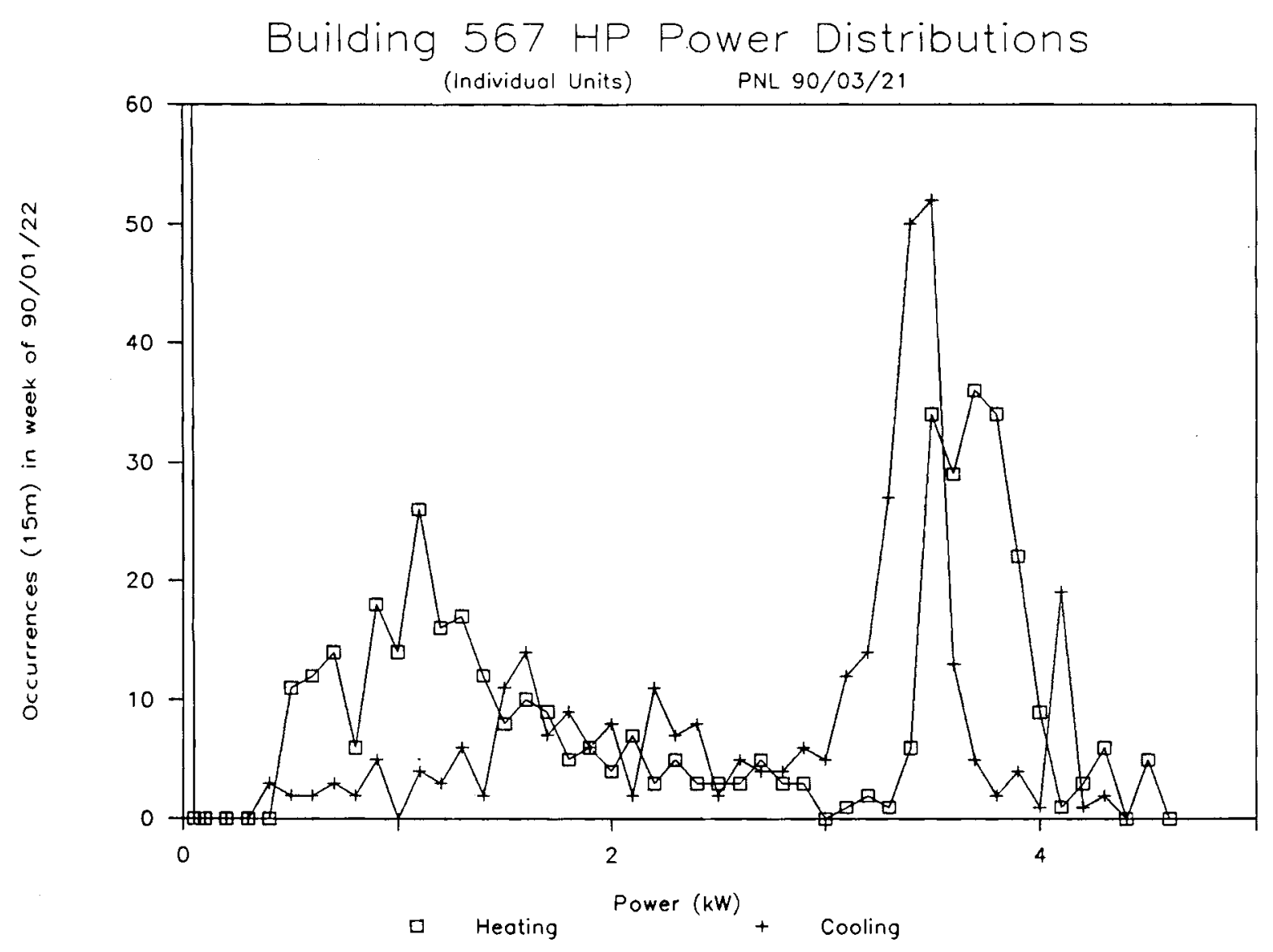

Building $567 \mathrm{HP}$ Power Distributions

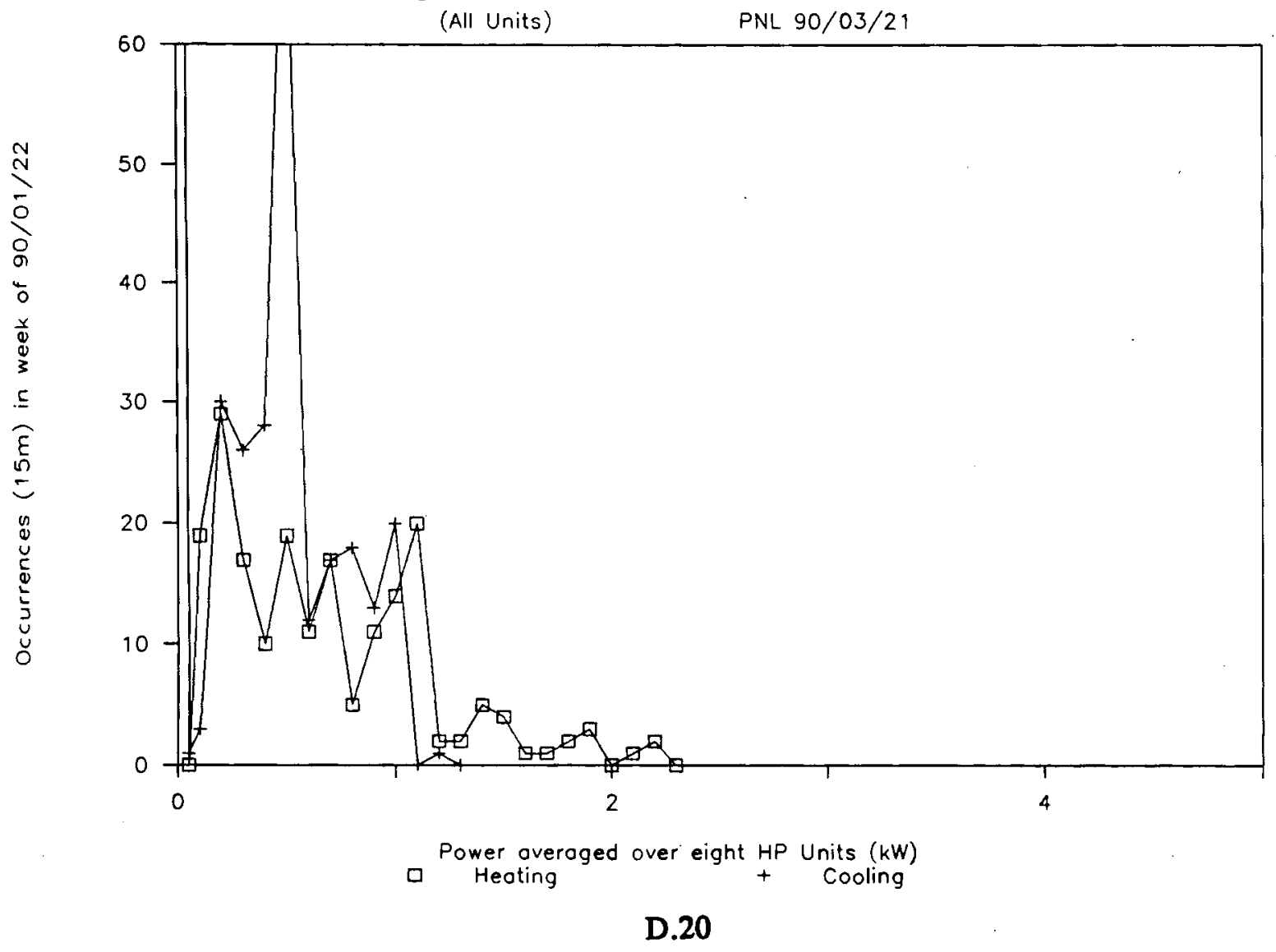



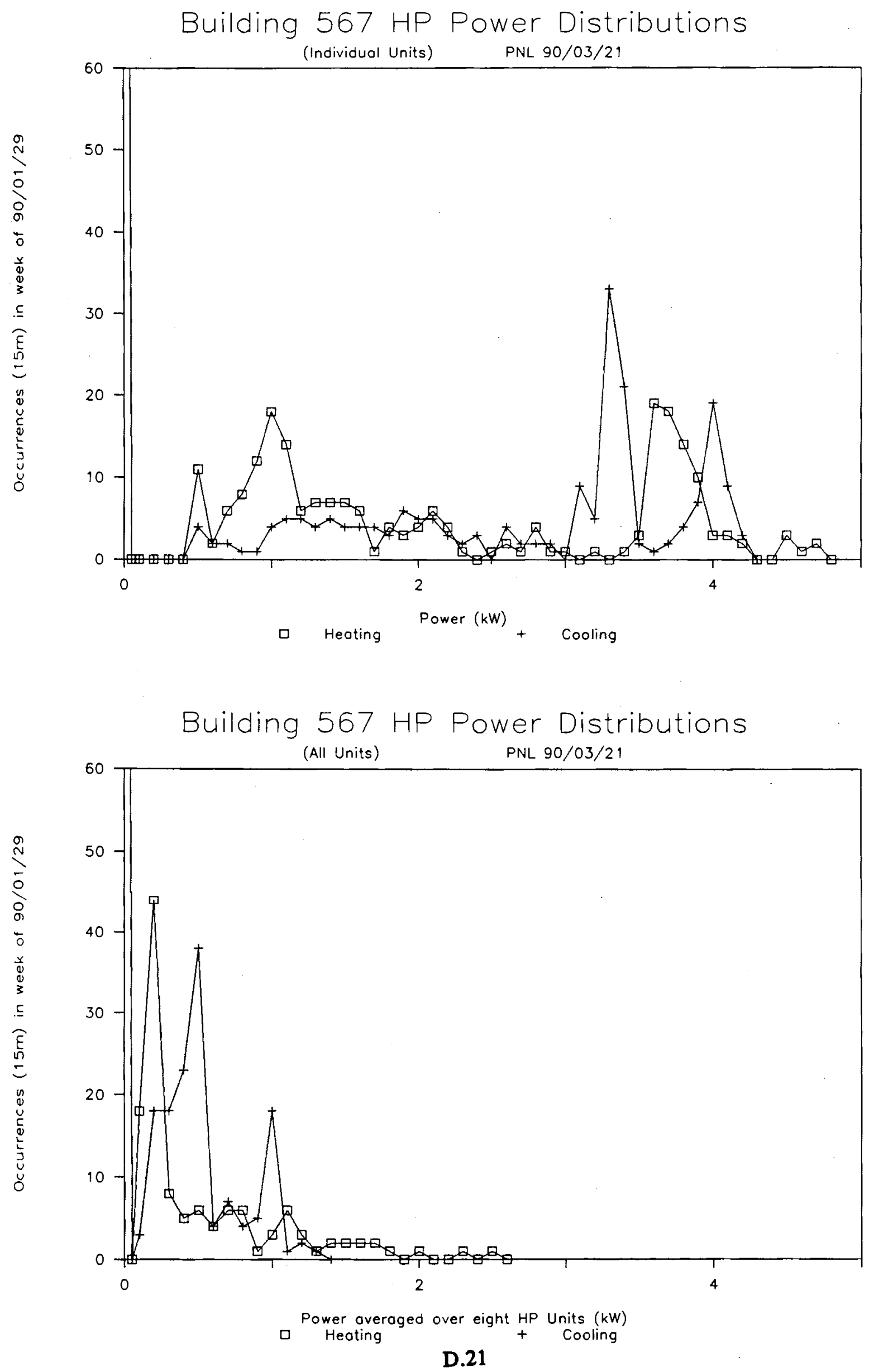


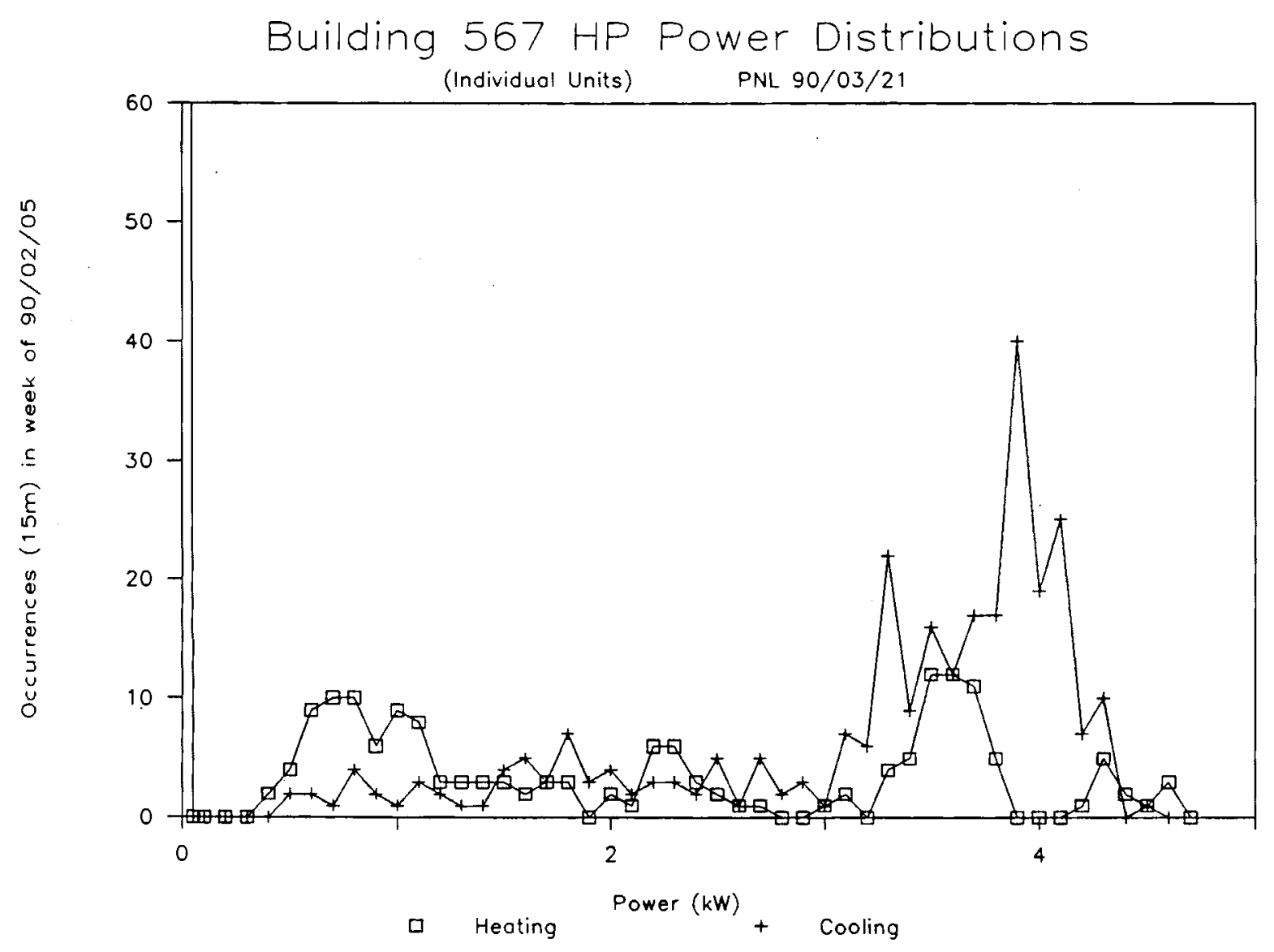

Building 567 HP Power Distributions

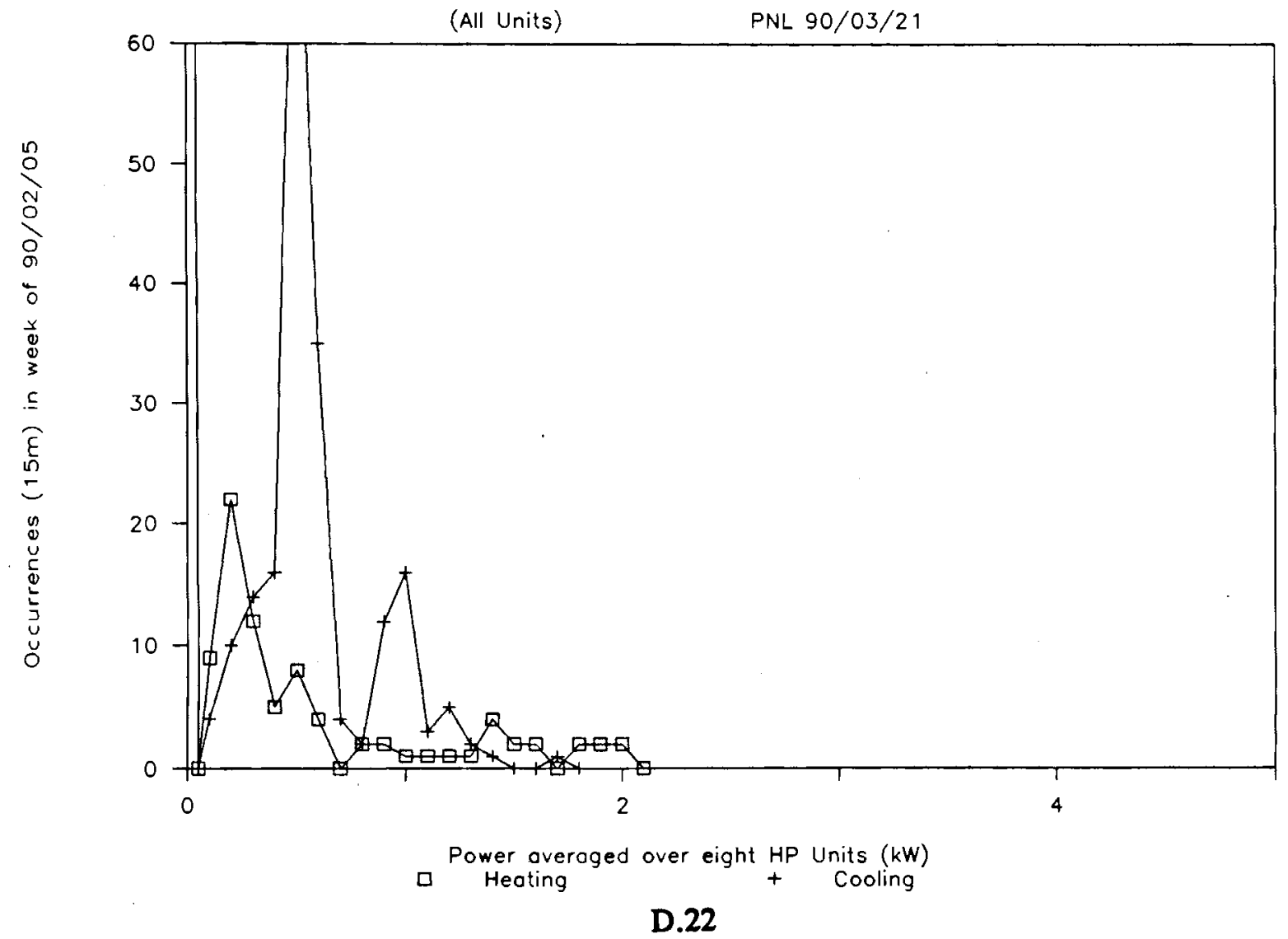




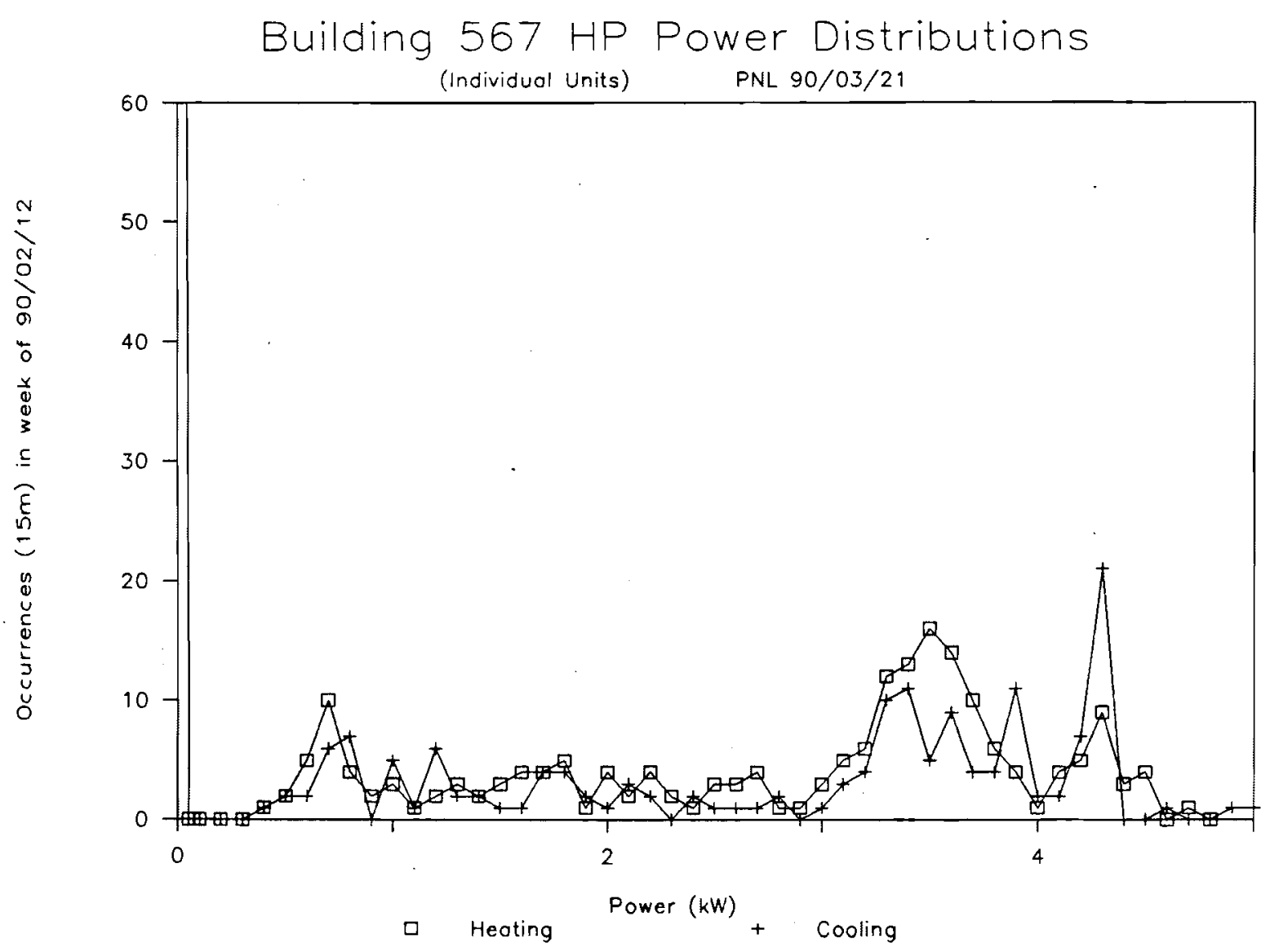

Building 567 HP Power Distributions

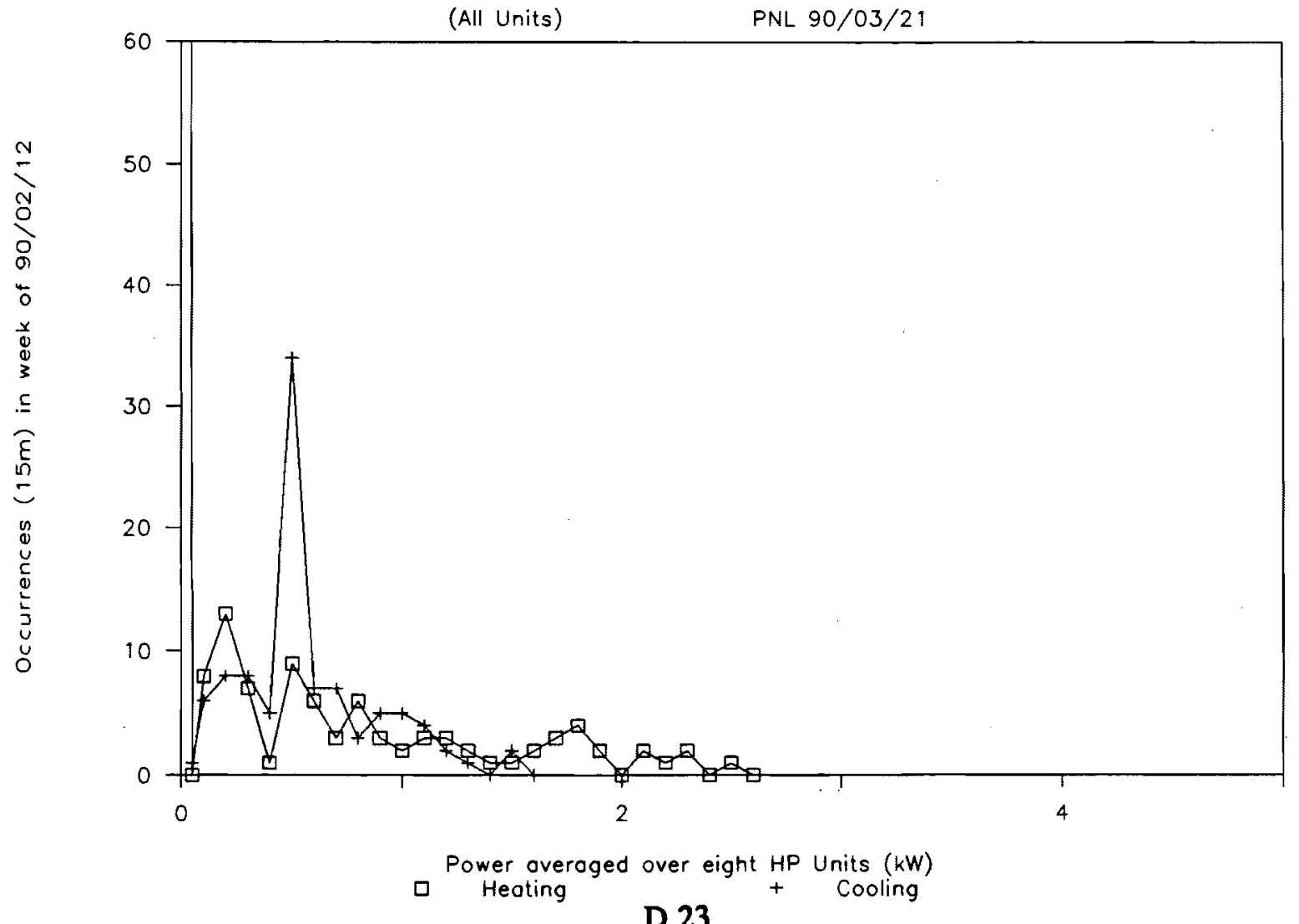




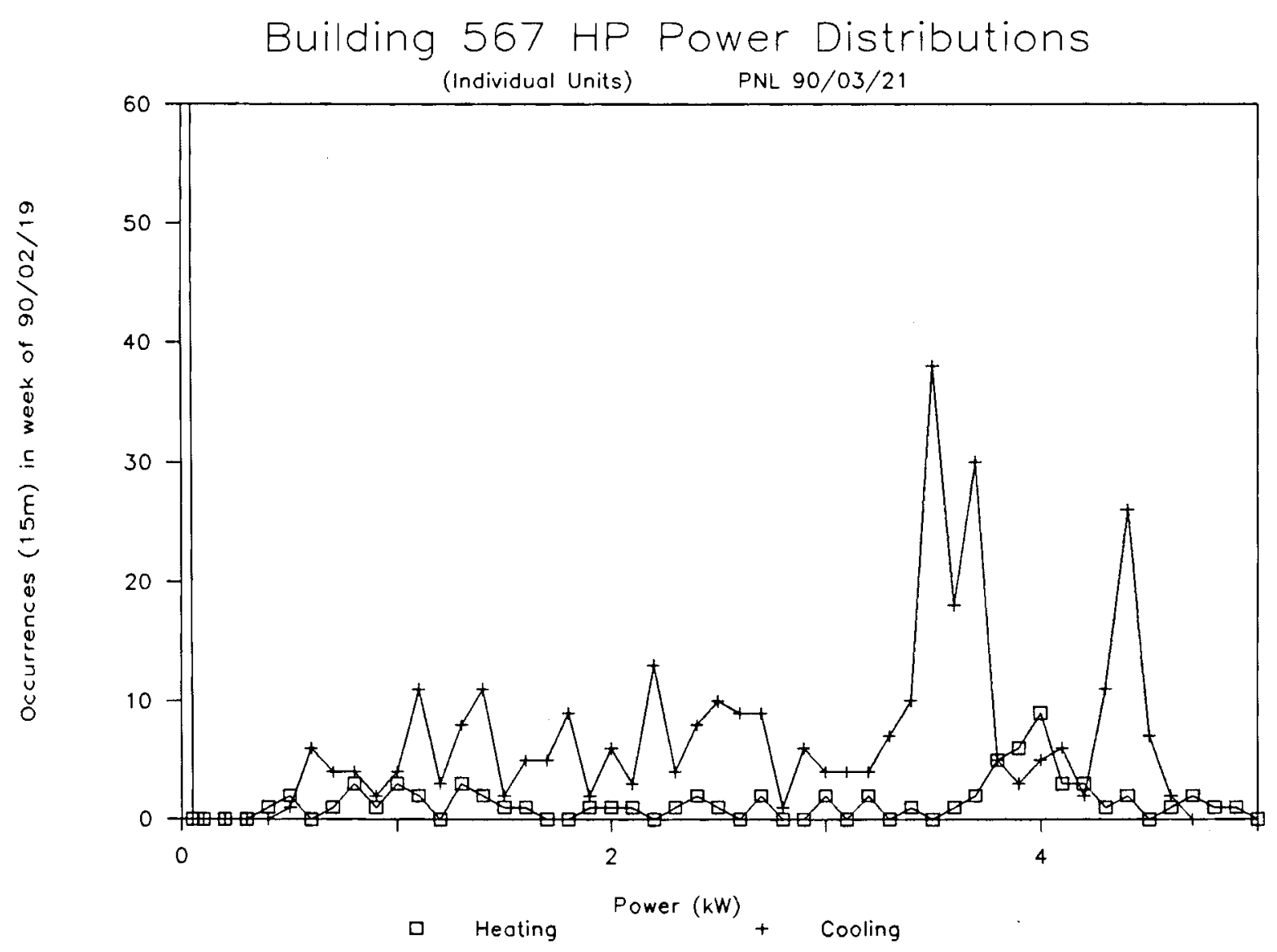

Building $567 \mathrm{HP}$ Power Distributions

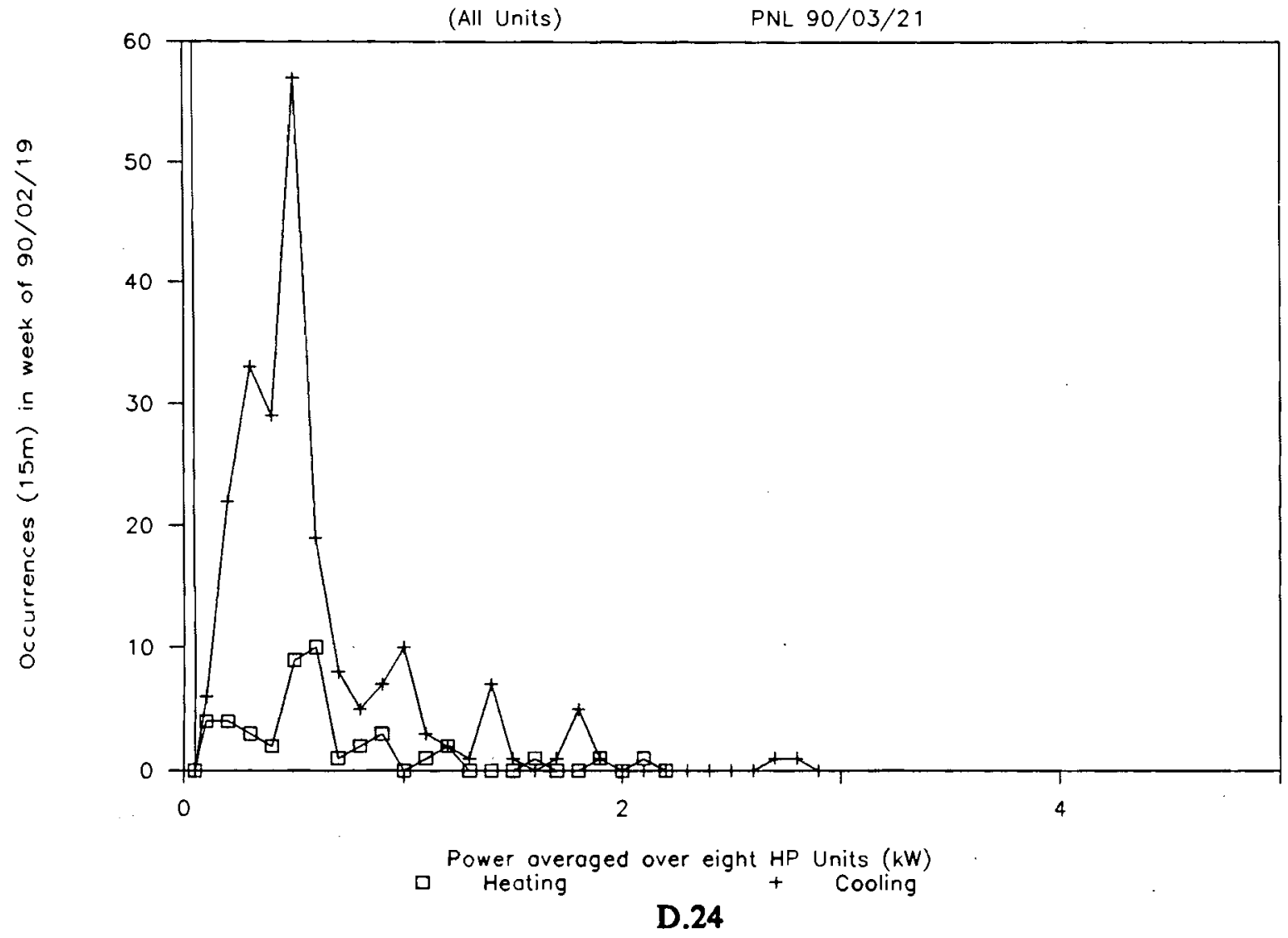



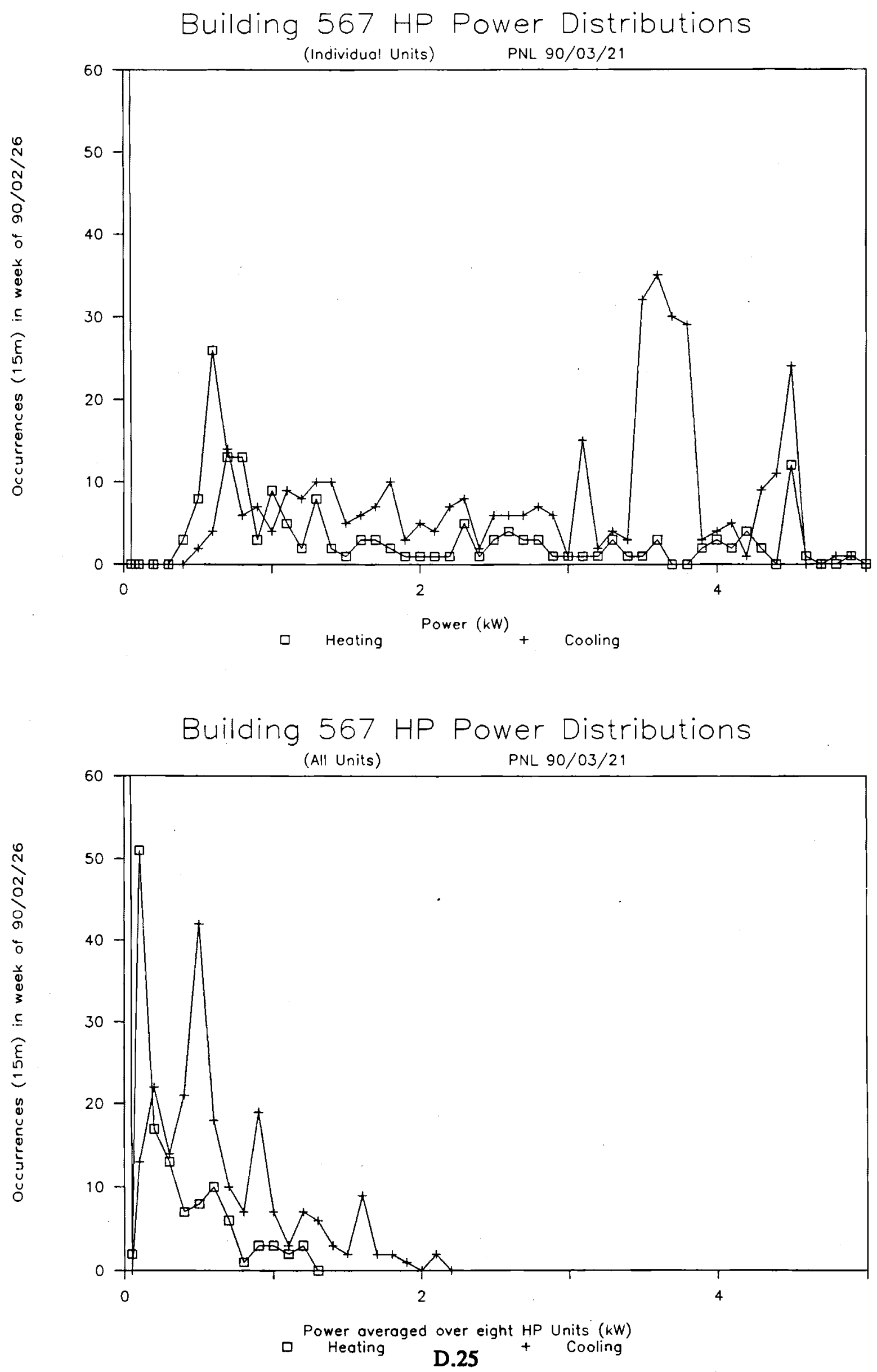

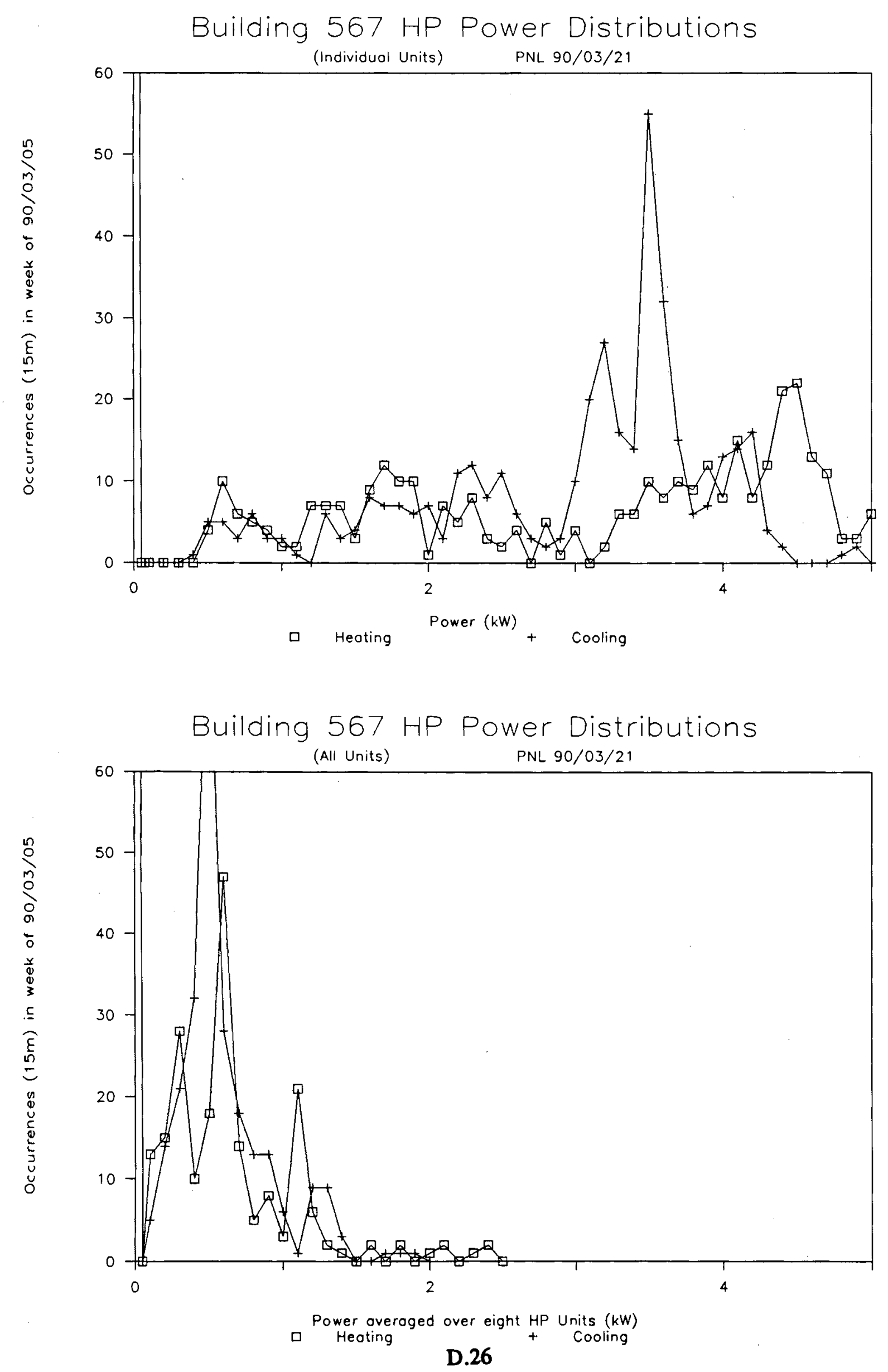

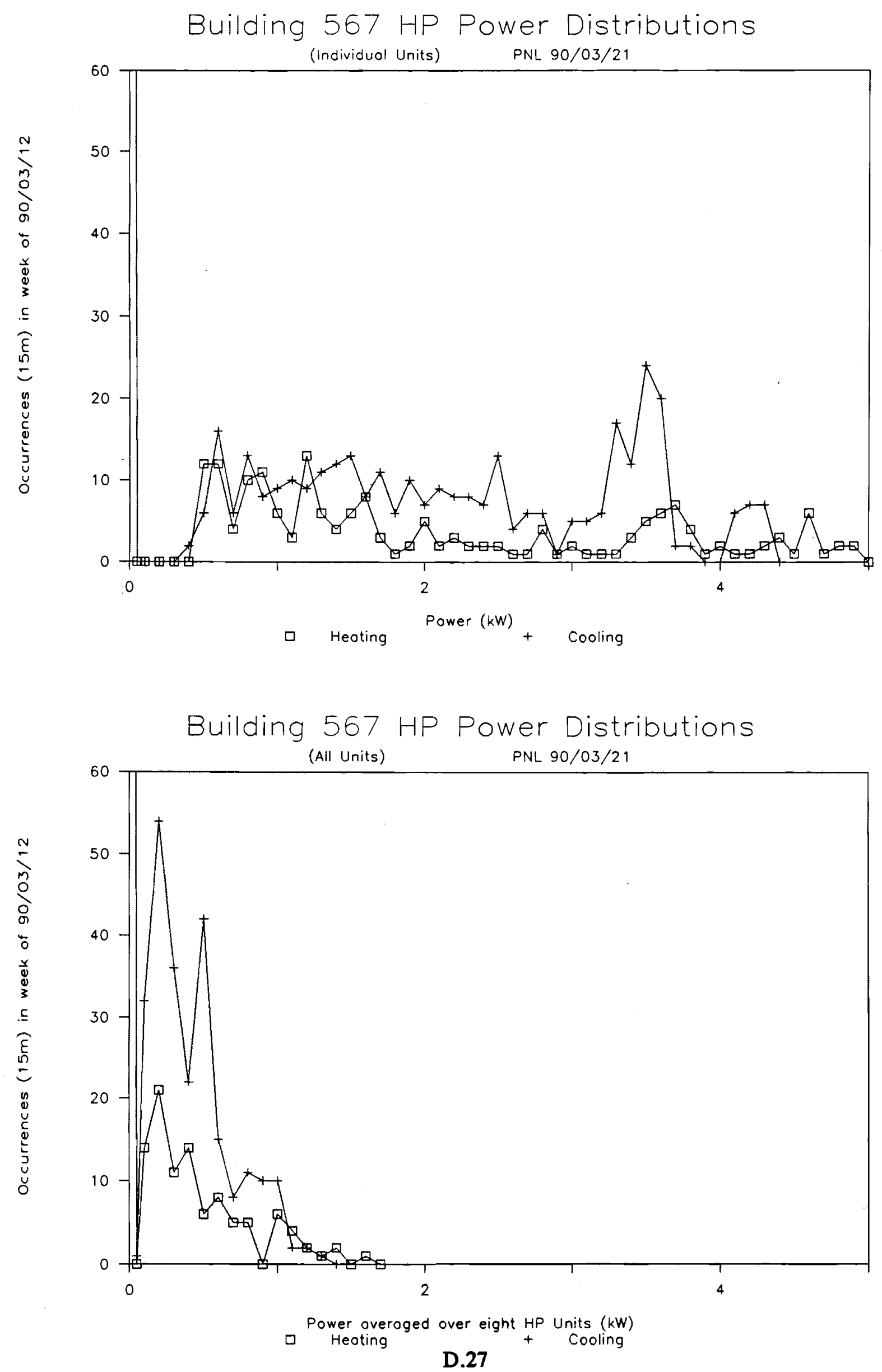

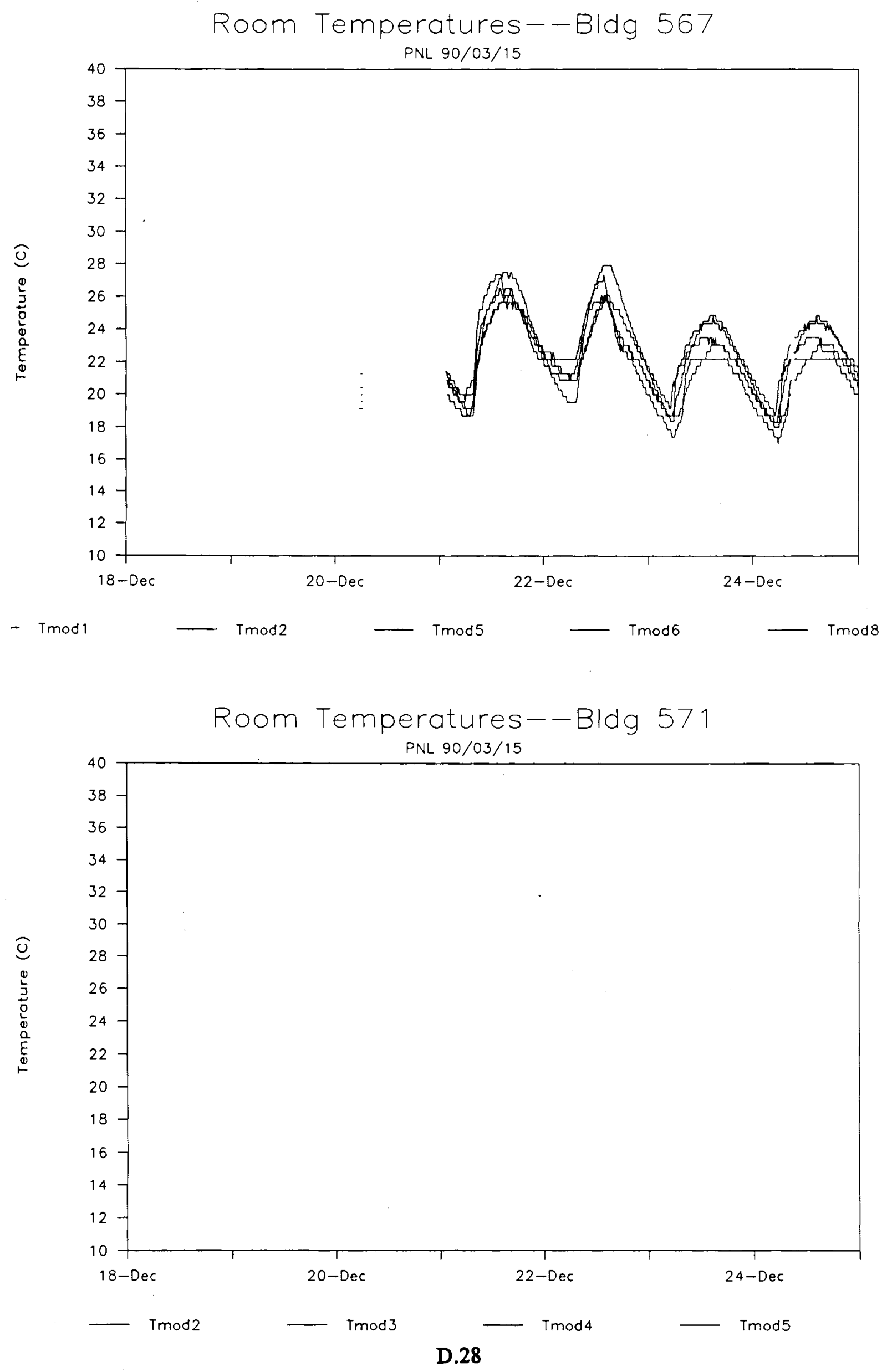

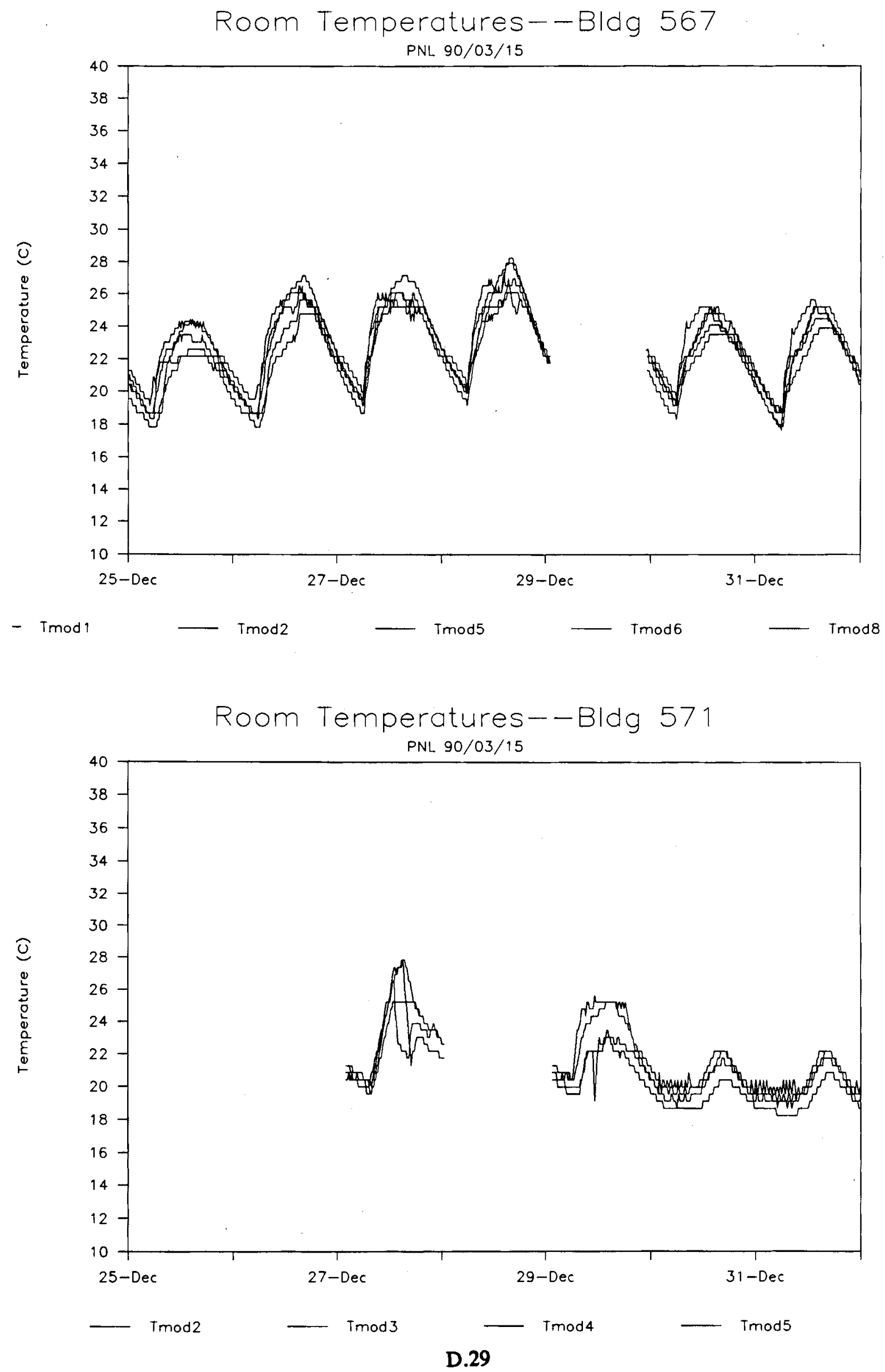

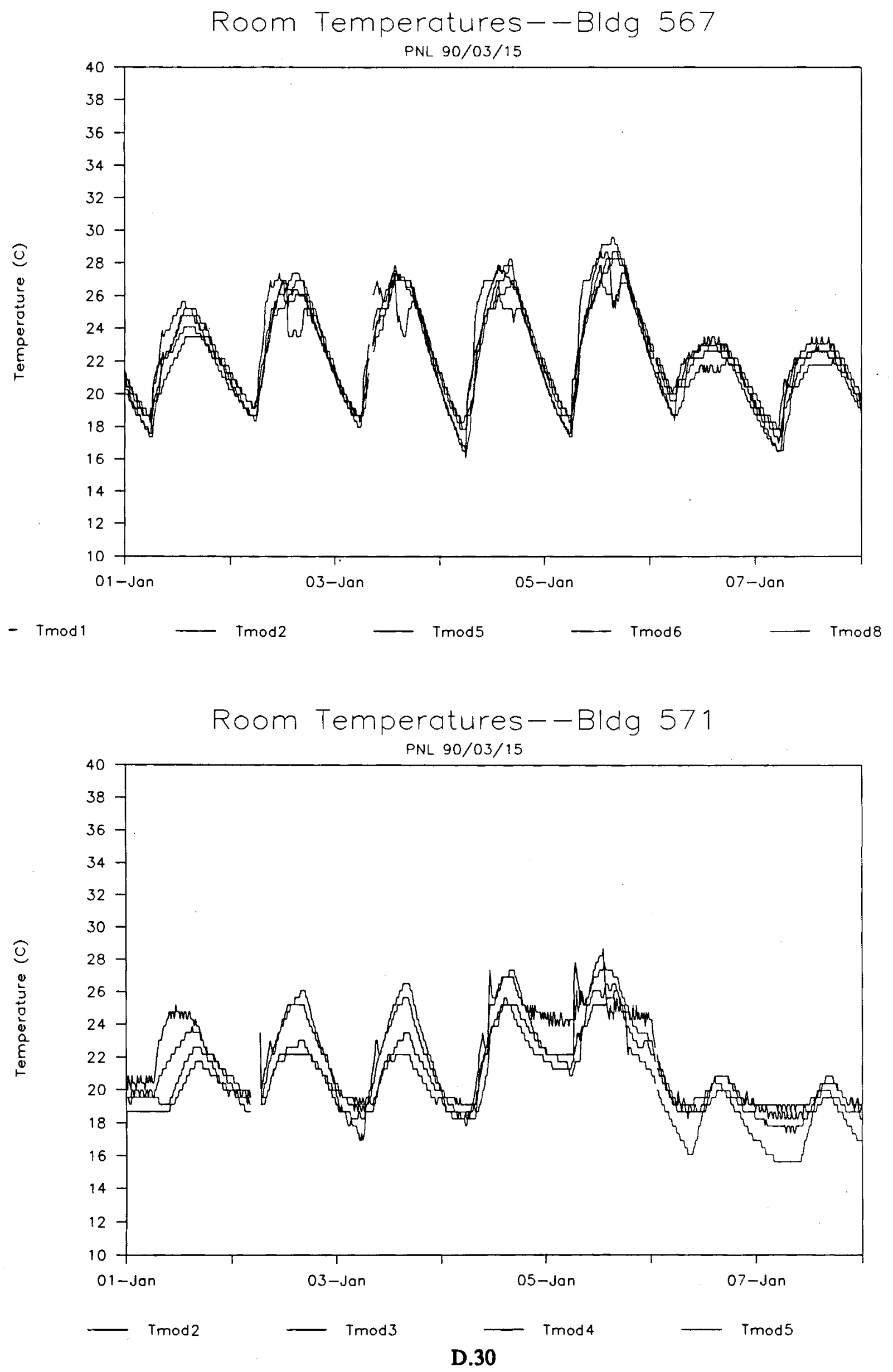

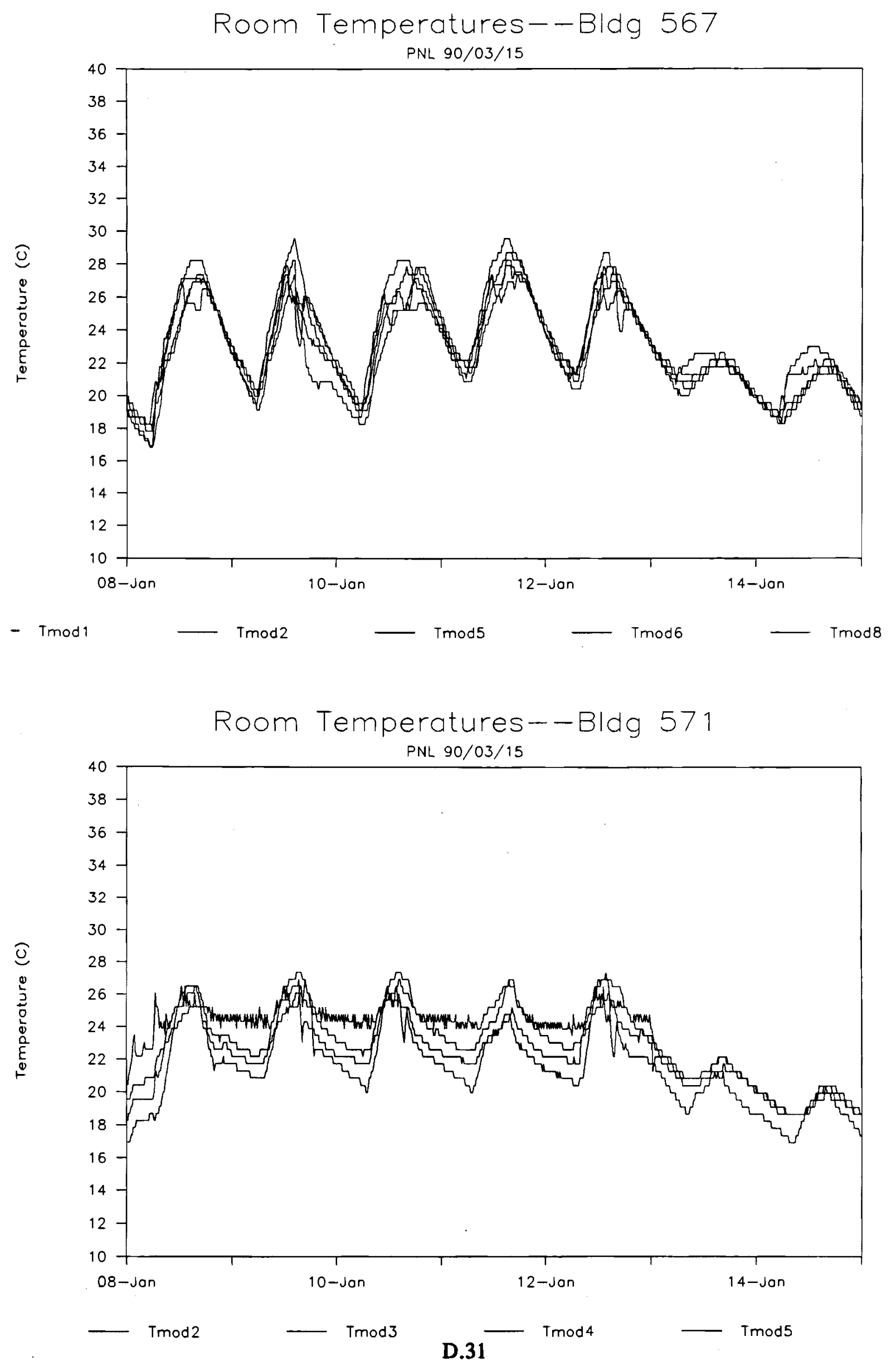


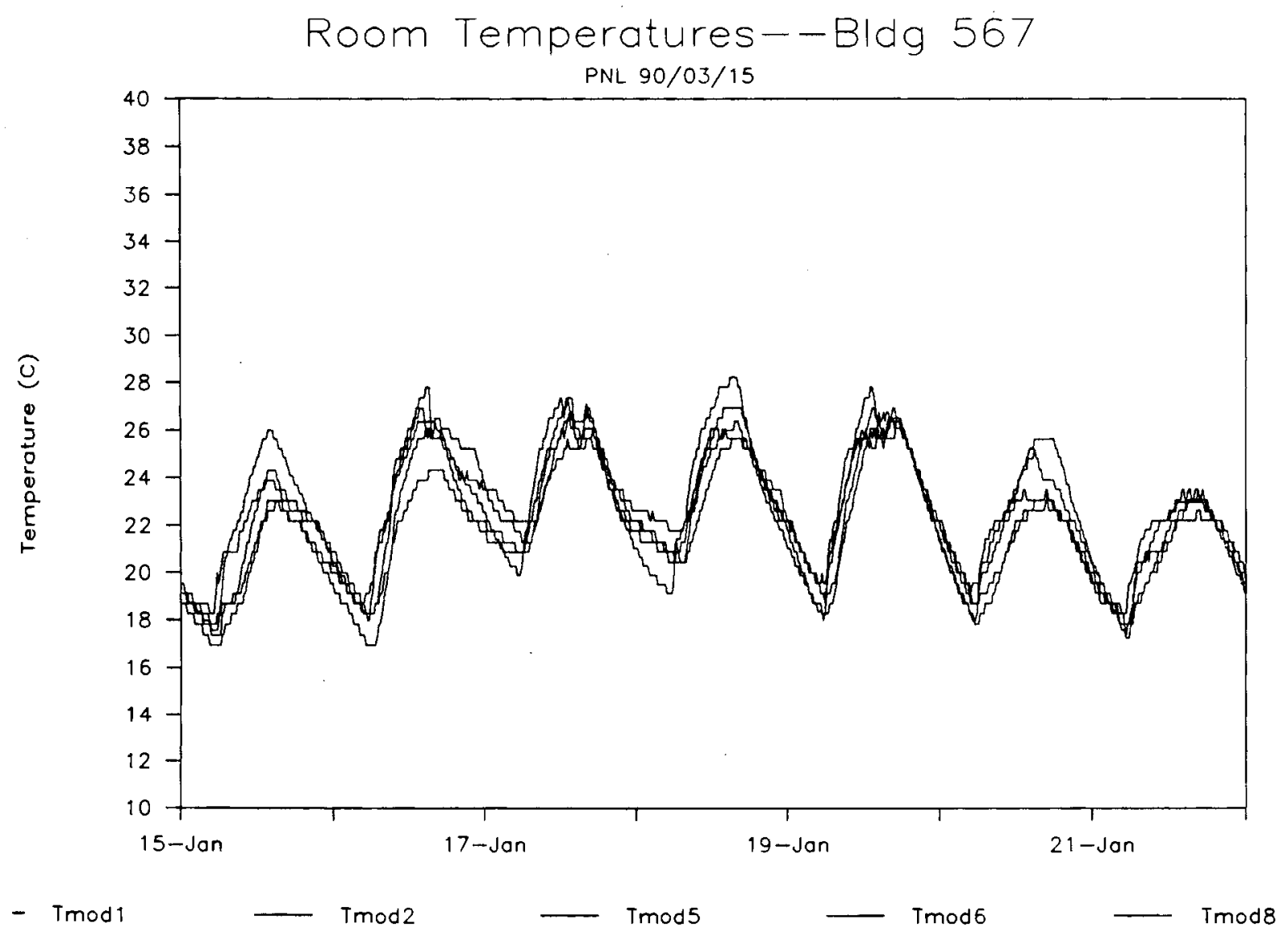

Room Temperatures--Bldg 571

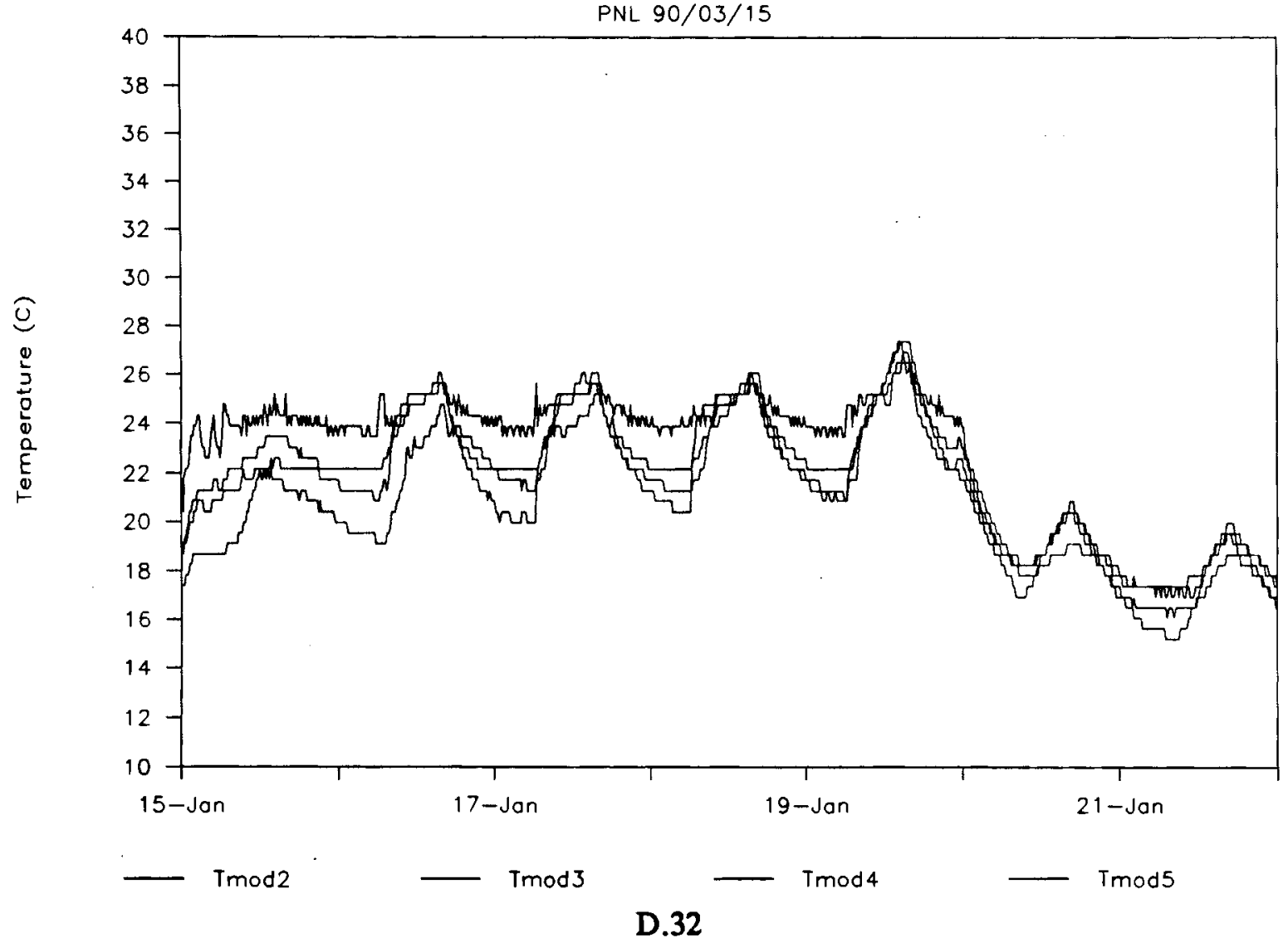



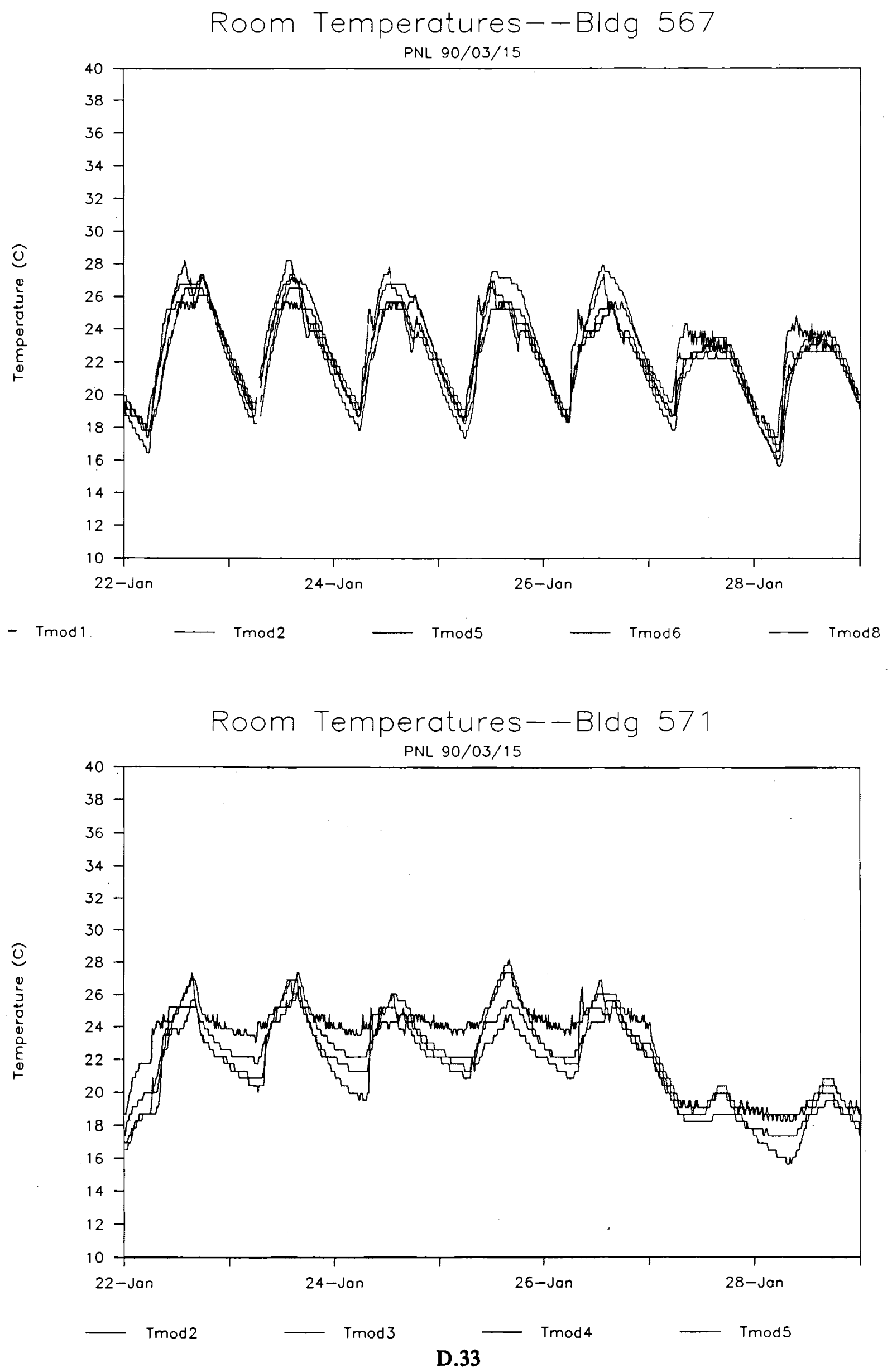

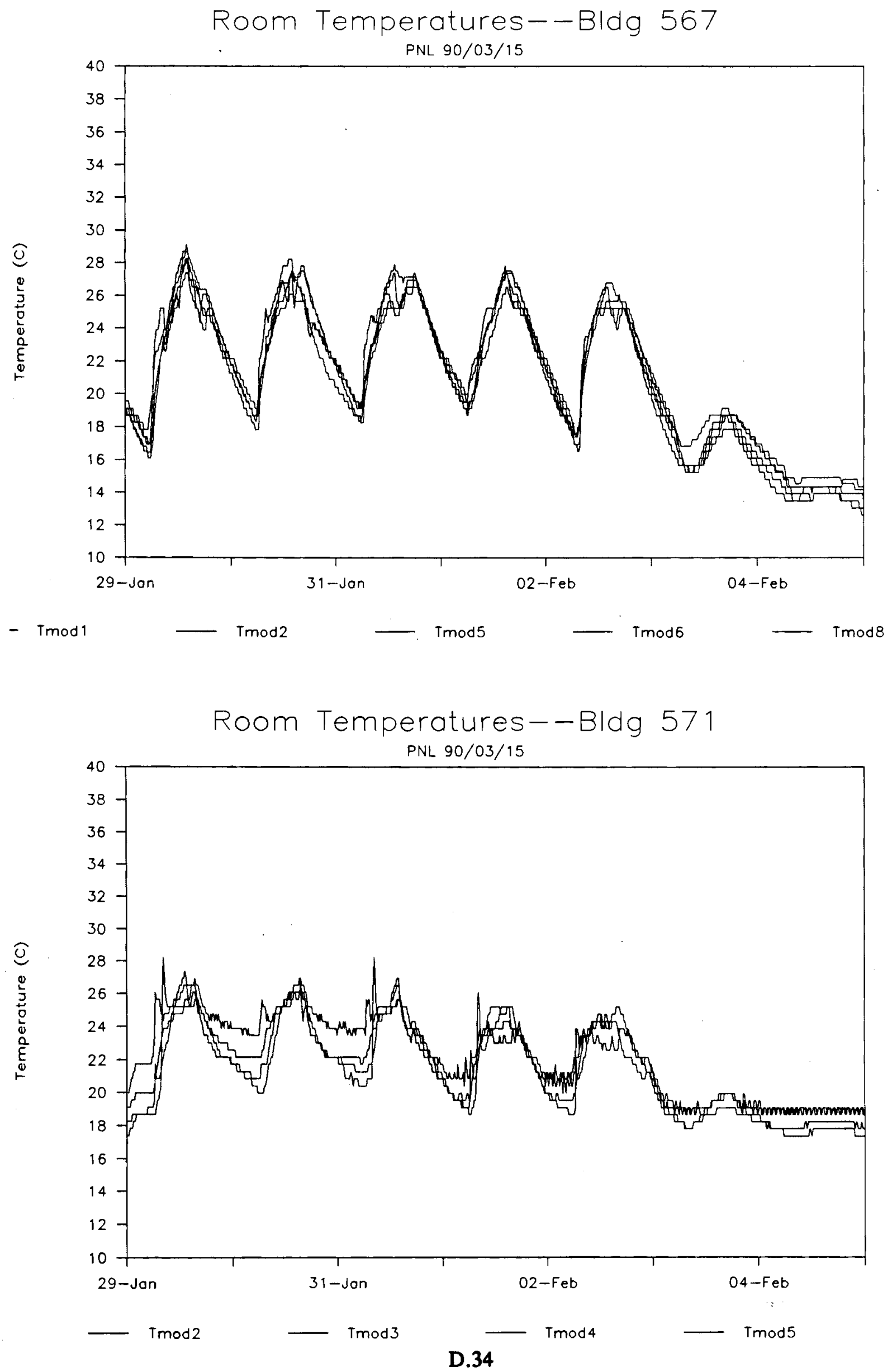

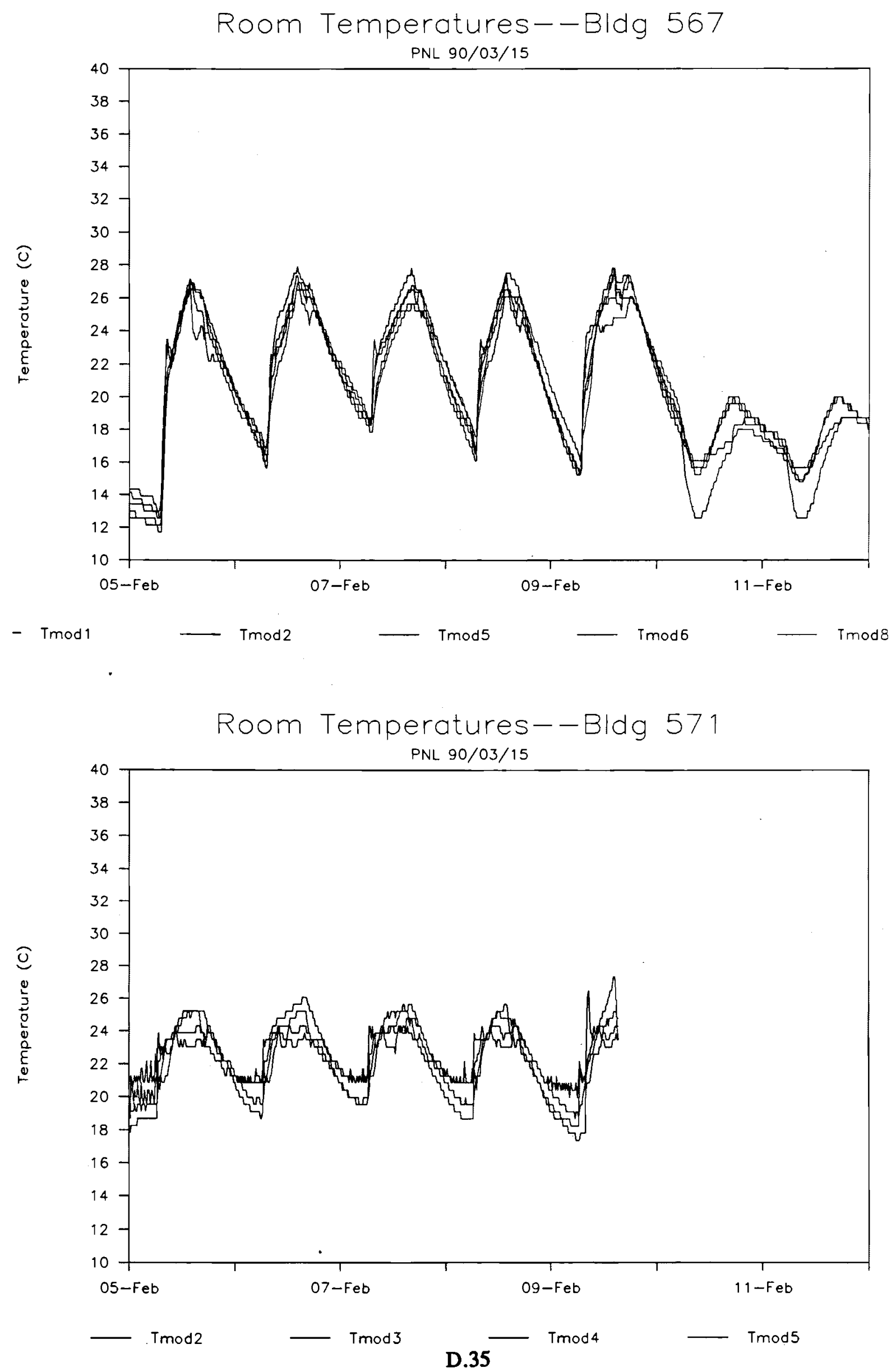


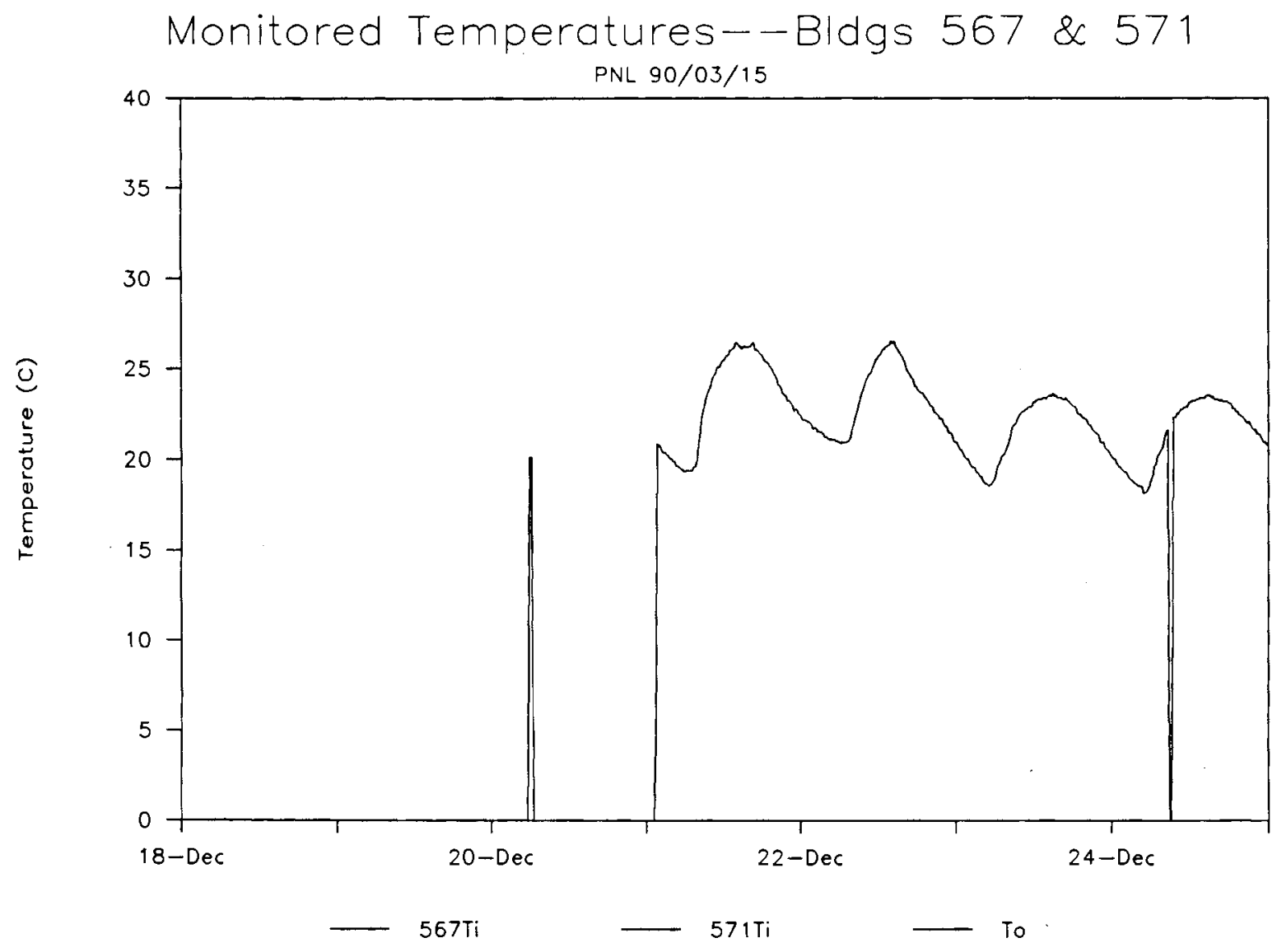

Monitored Temperatures--Bldgs 567 \& 571

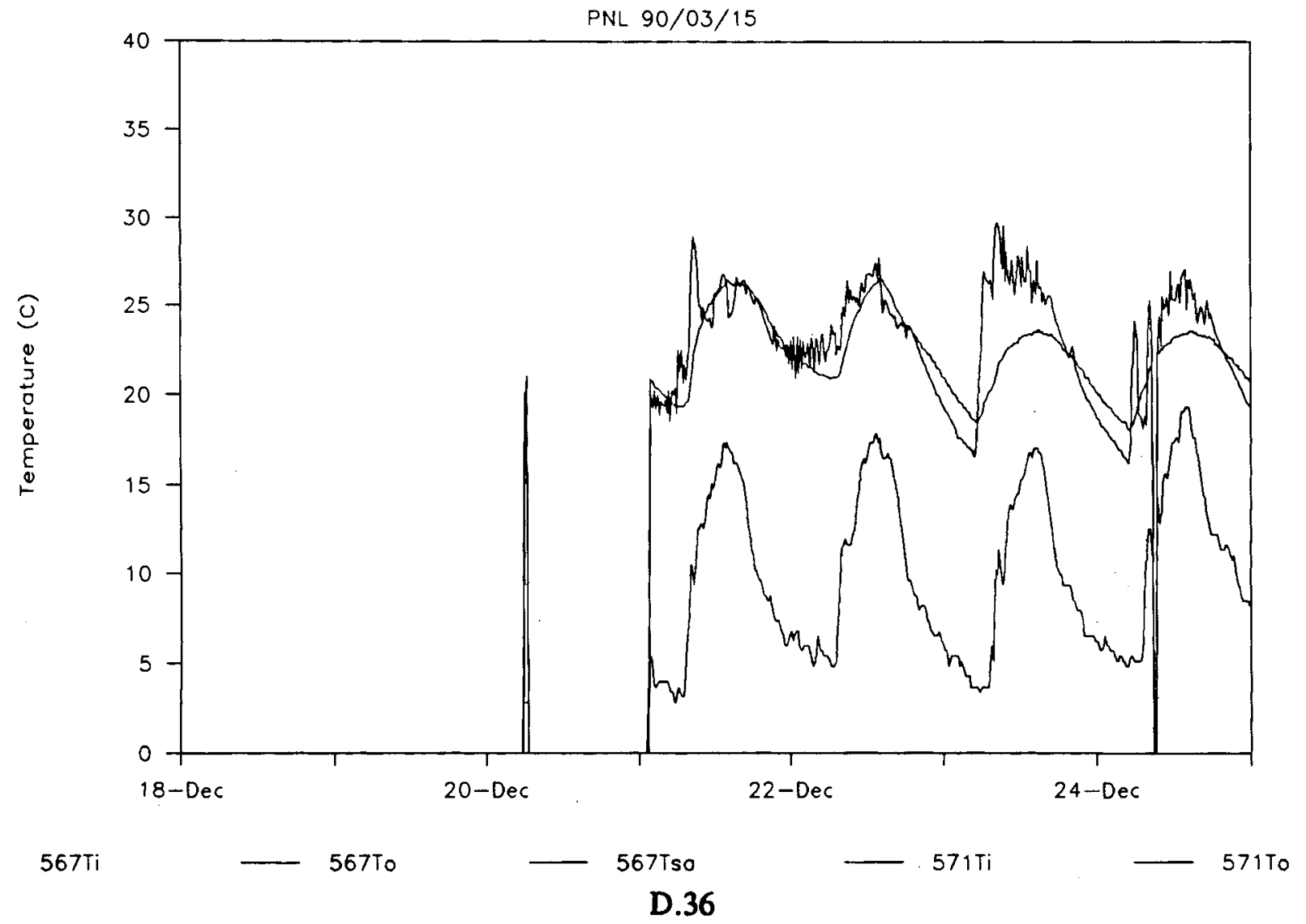


Monitored Temperatures--Bldgs 567 \& 571
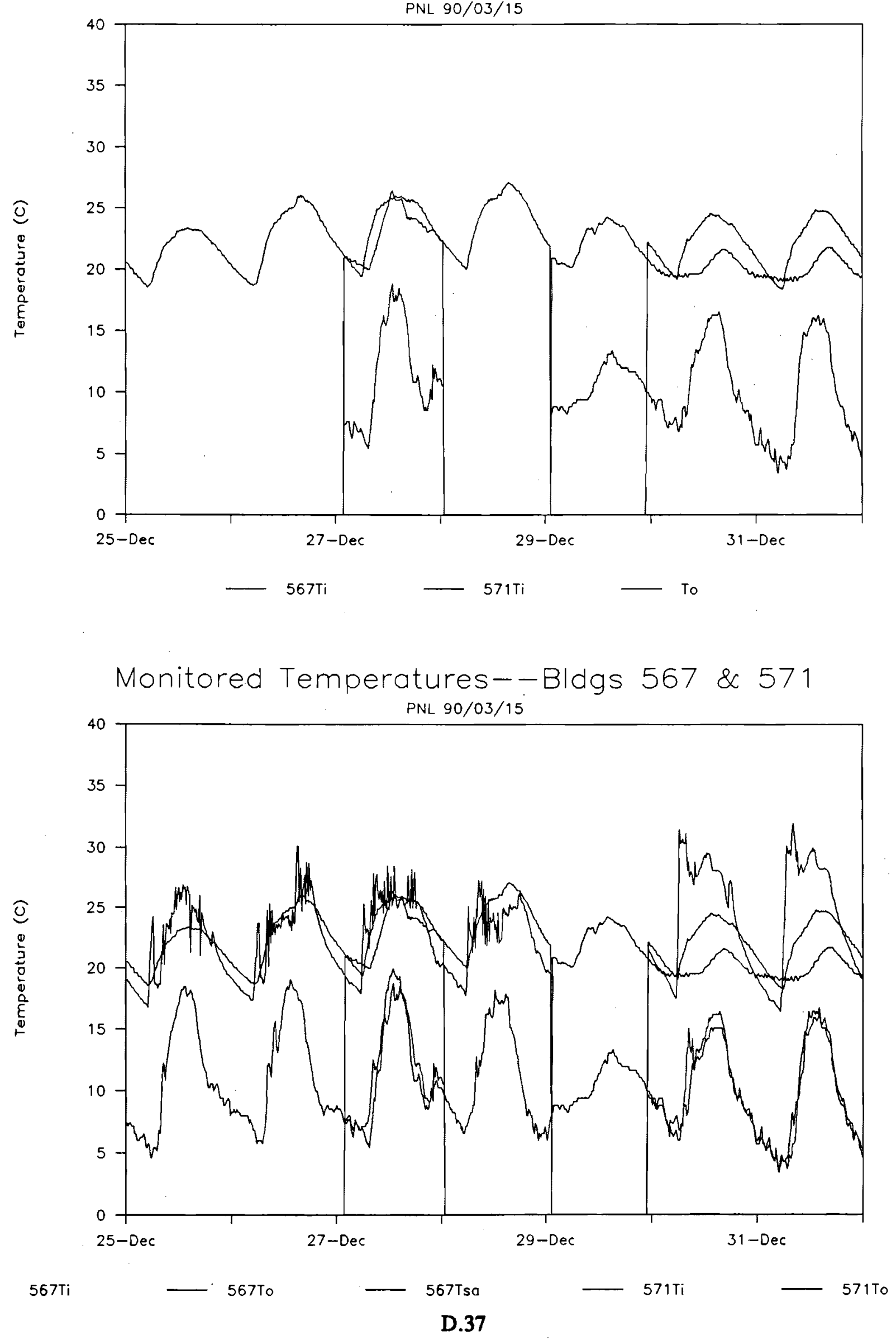


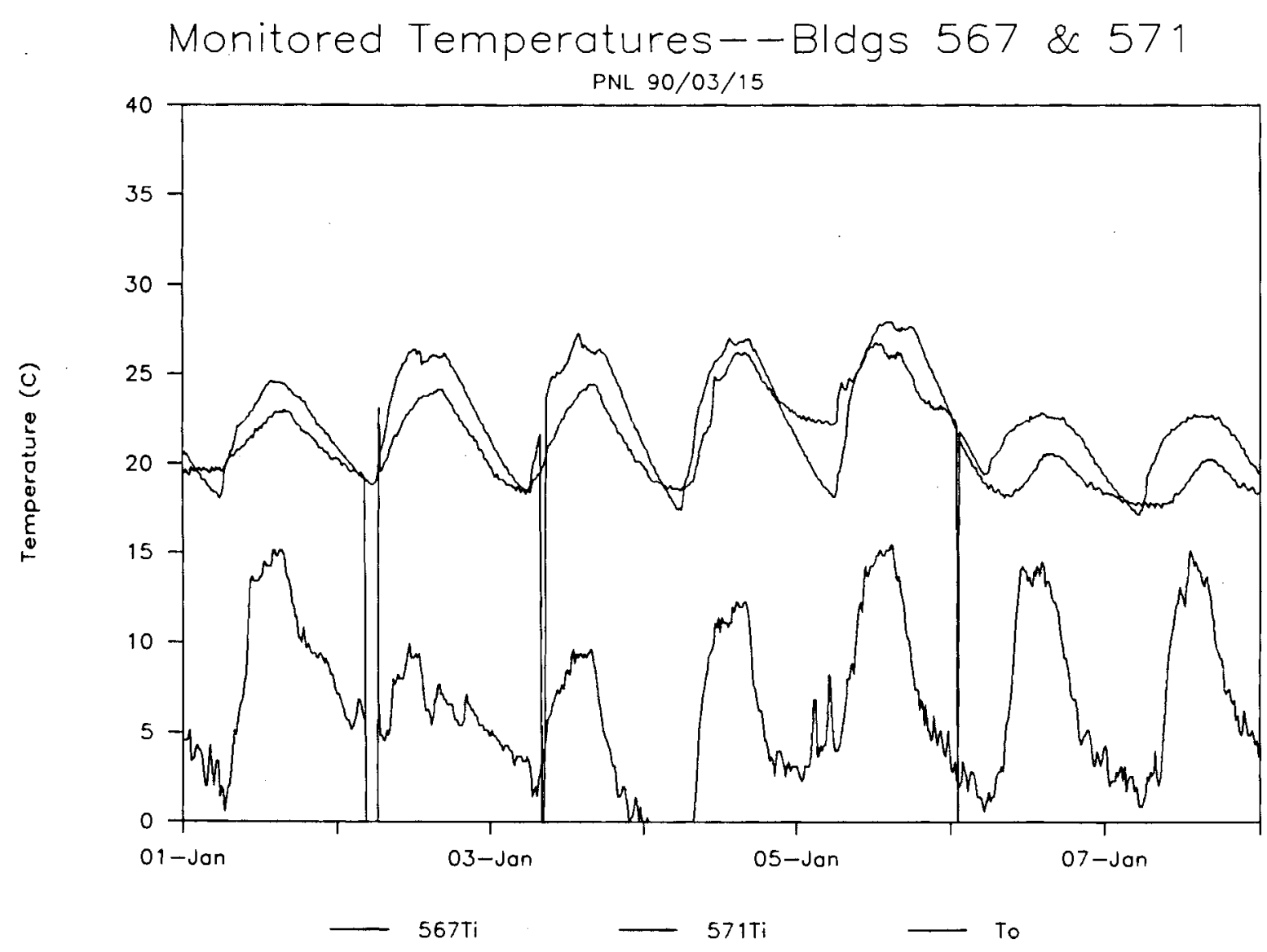

Monitored Temperatures--Bldgs $567 \& 571$

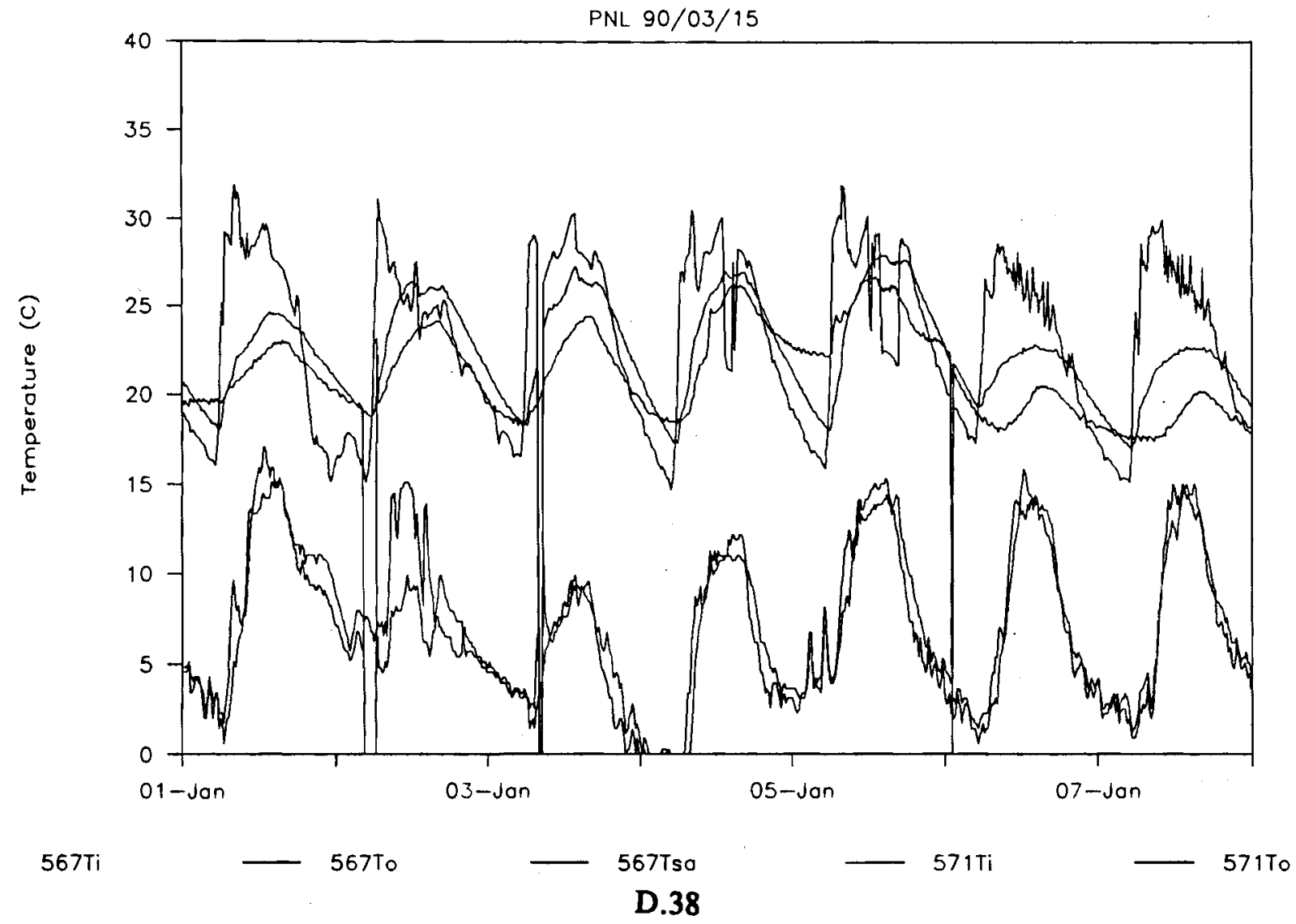



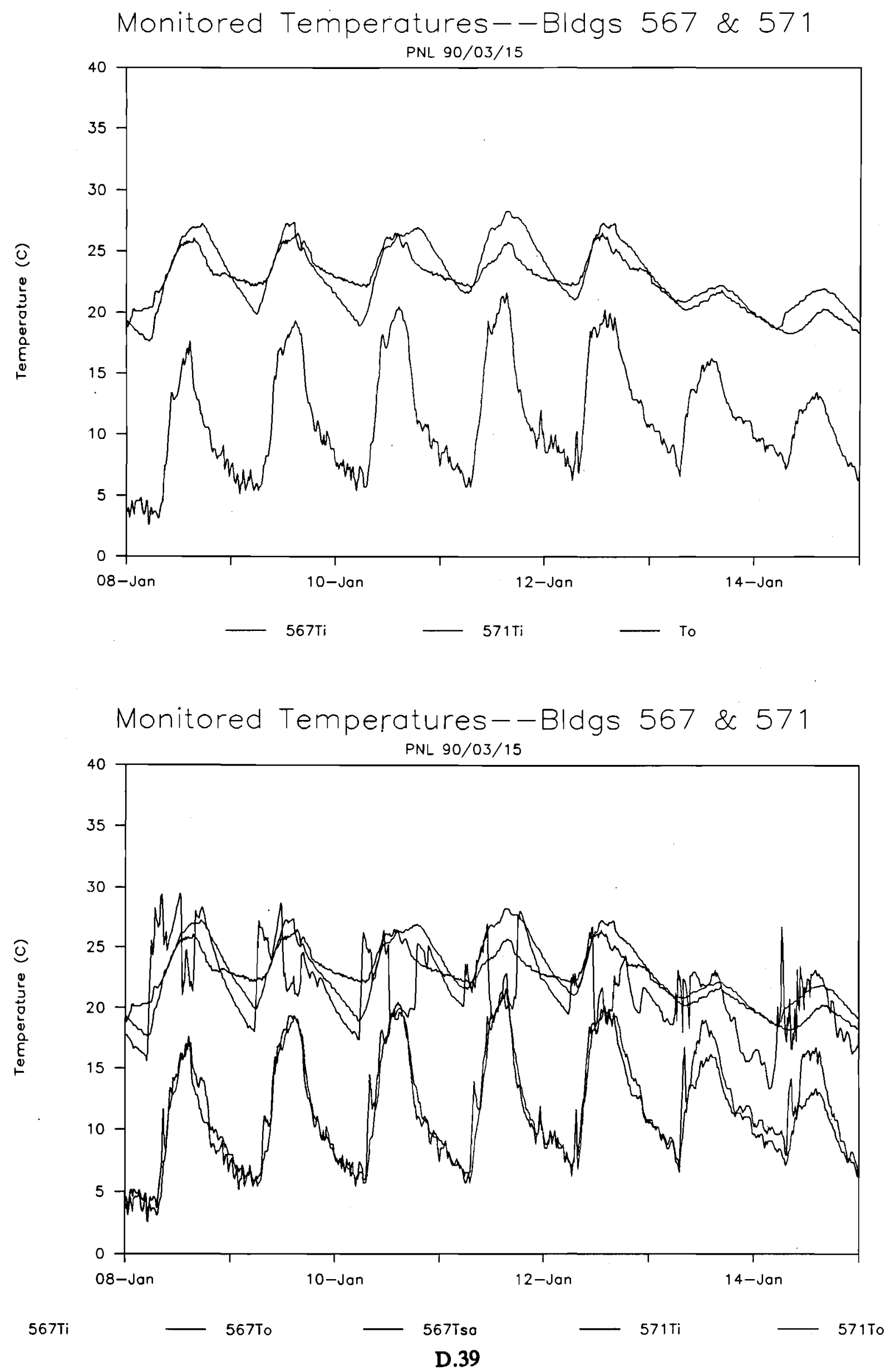


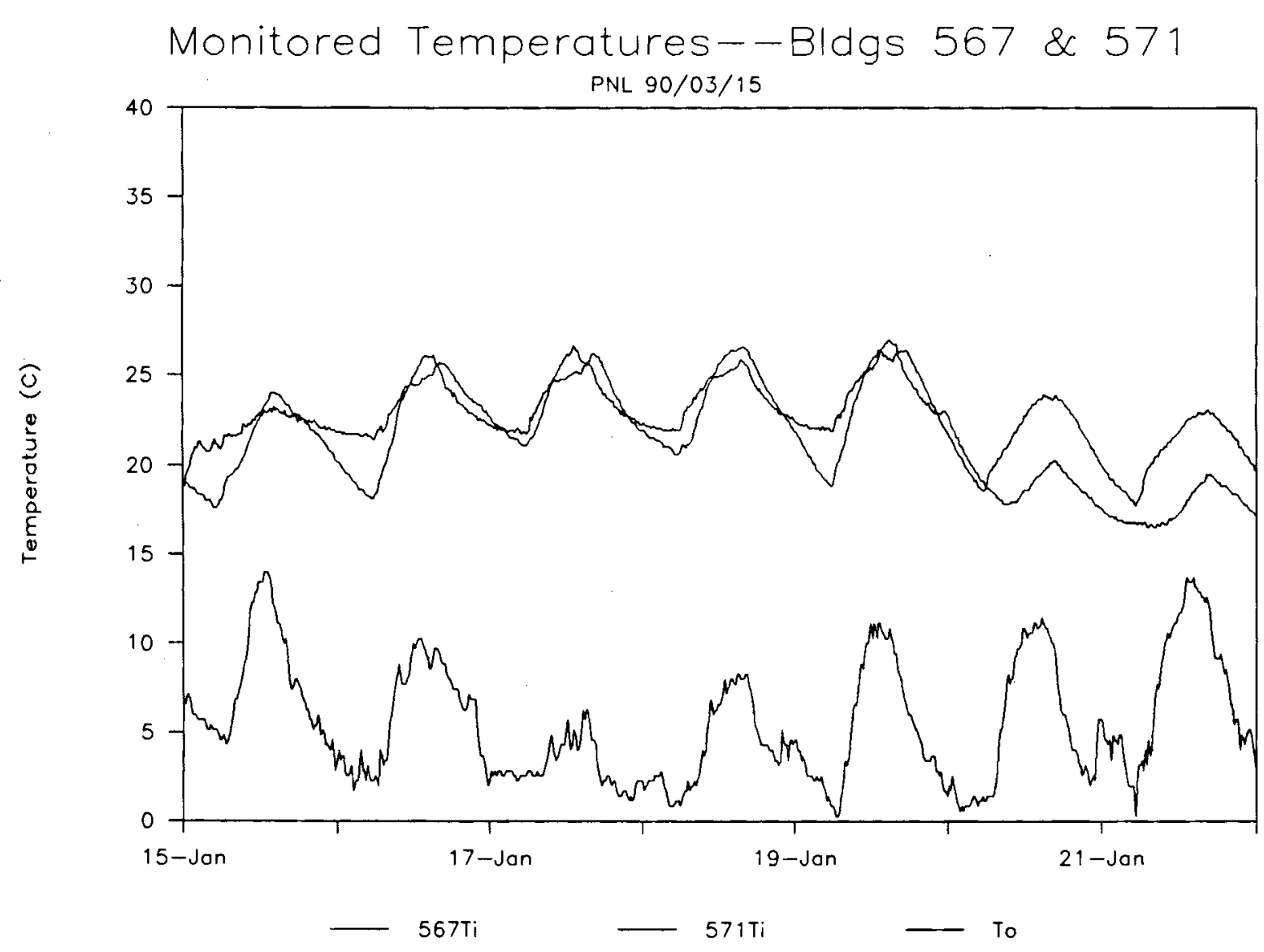

Monitored Temperatures--Bldgs 567 \& 571

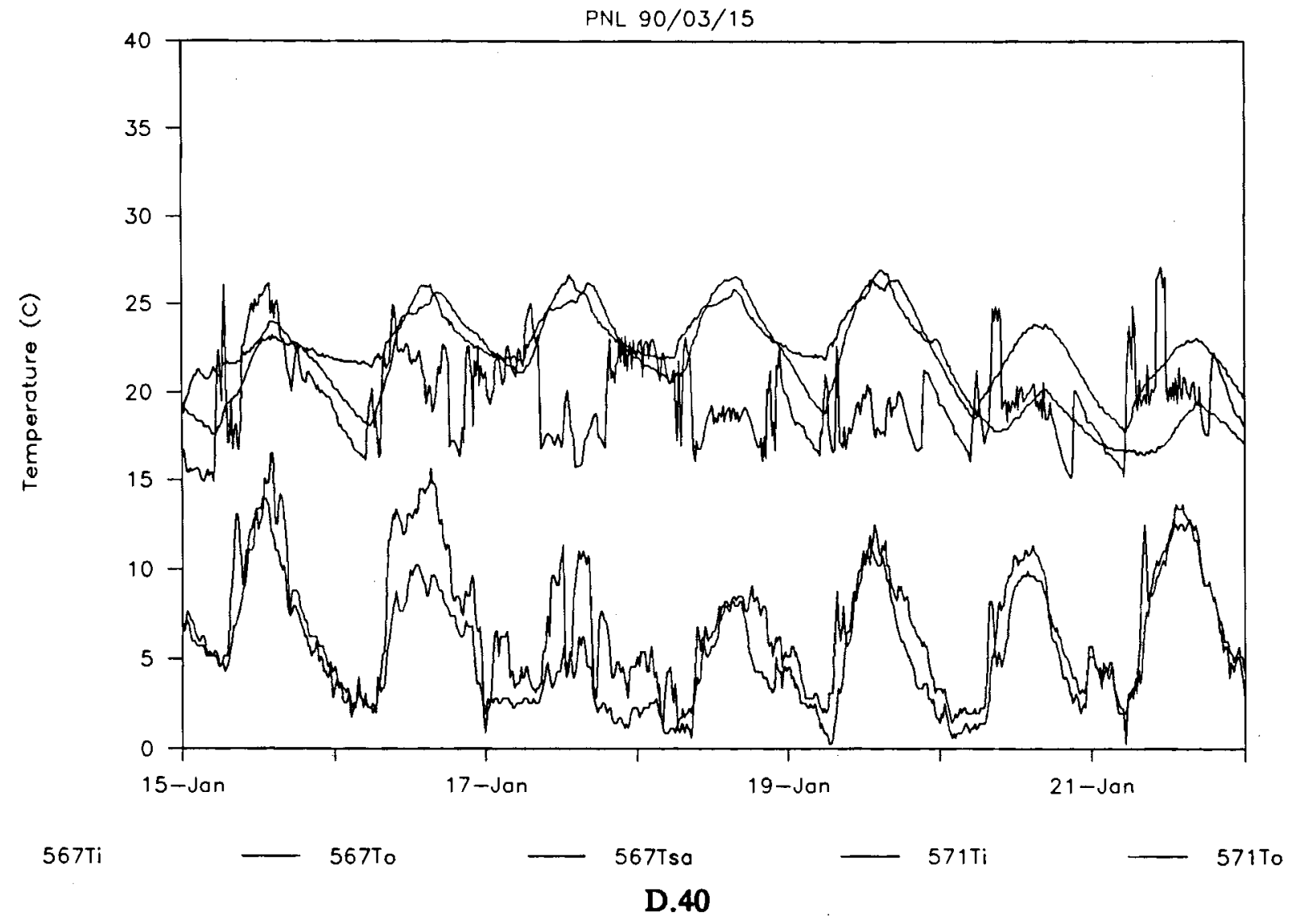



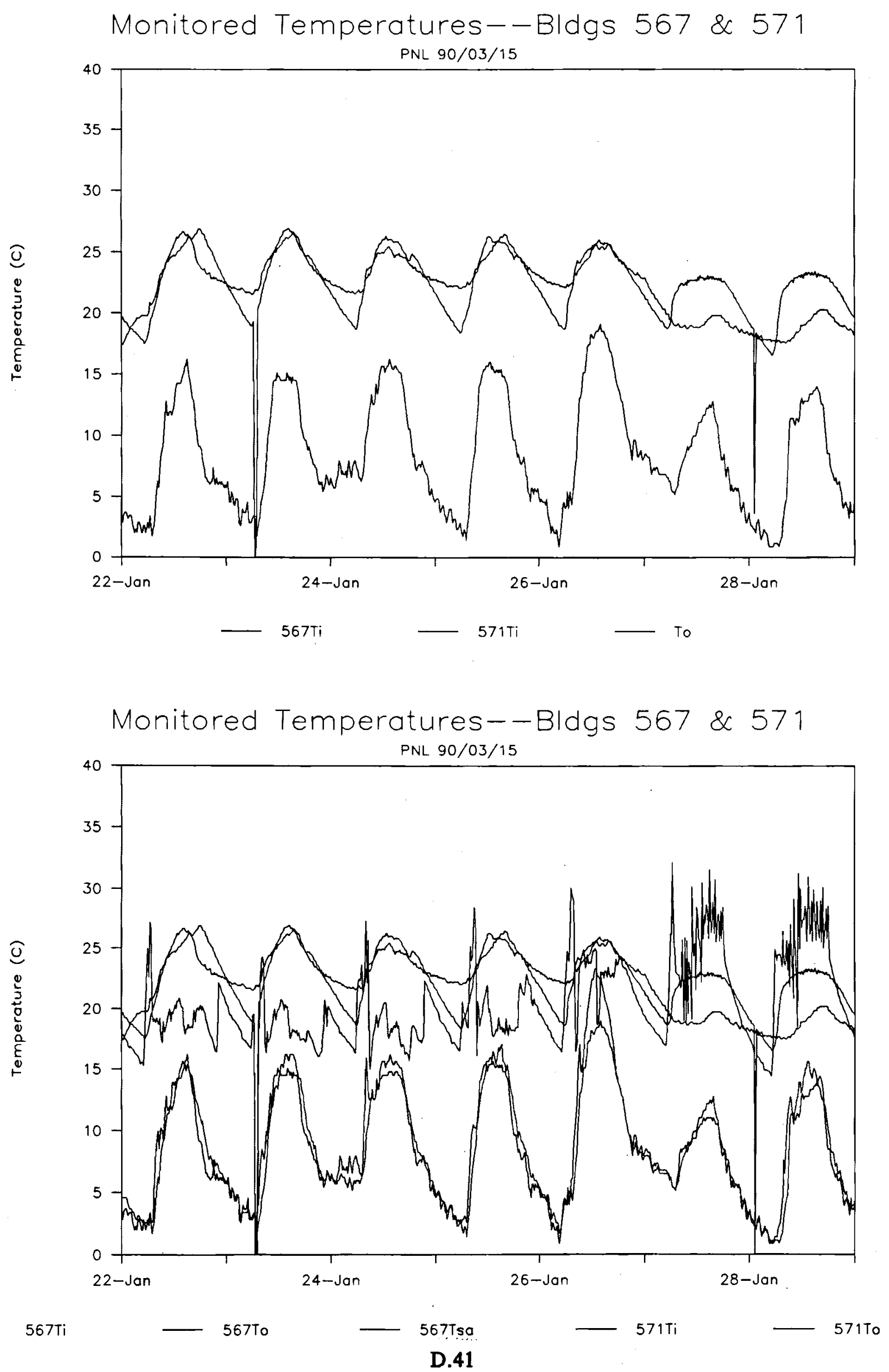


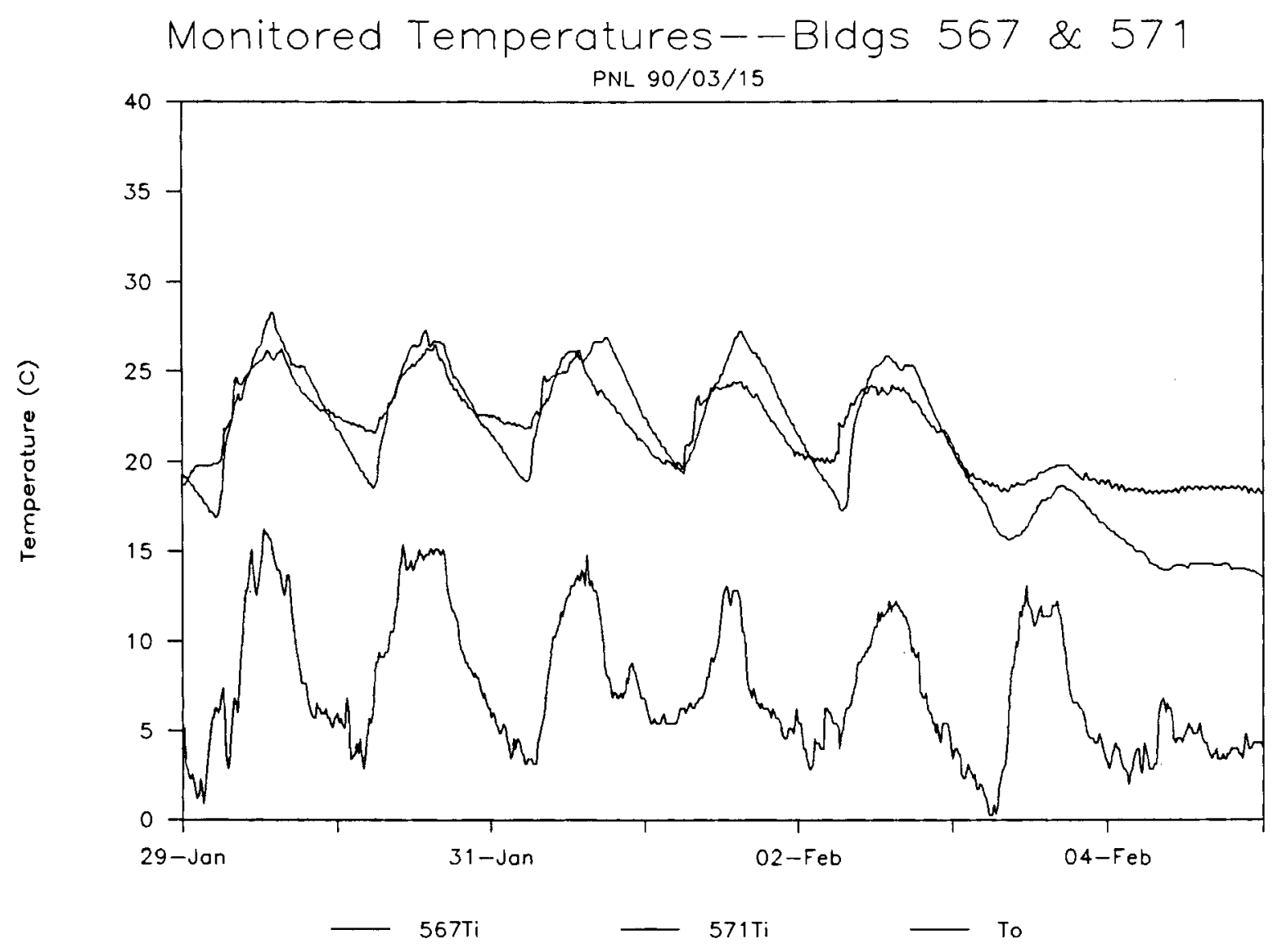

Monitored Temperatures--Bldgs $567 \& 571$

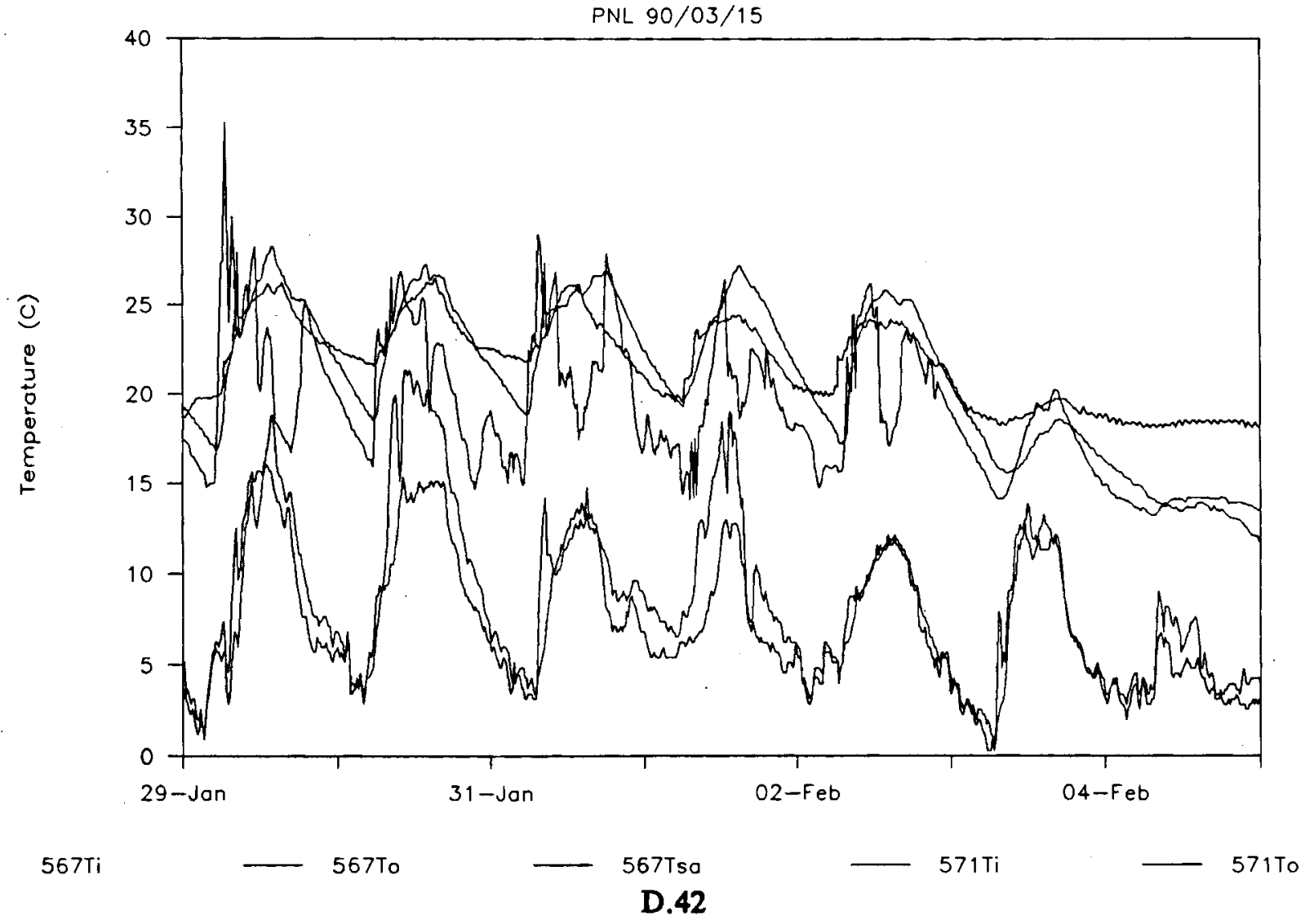



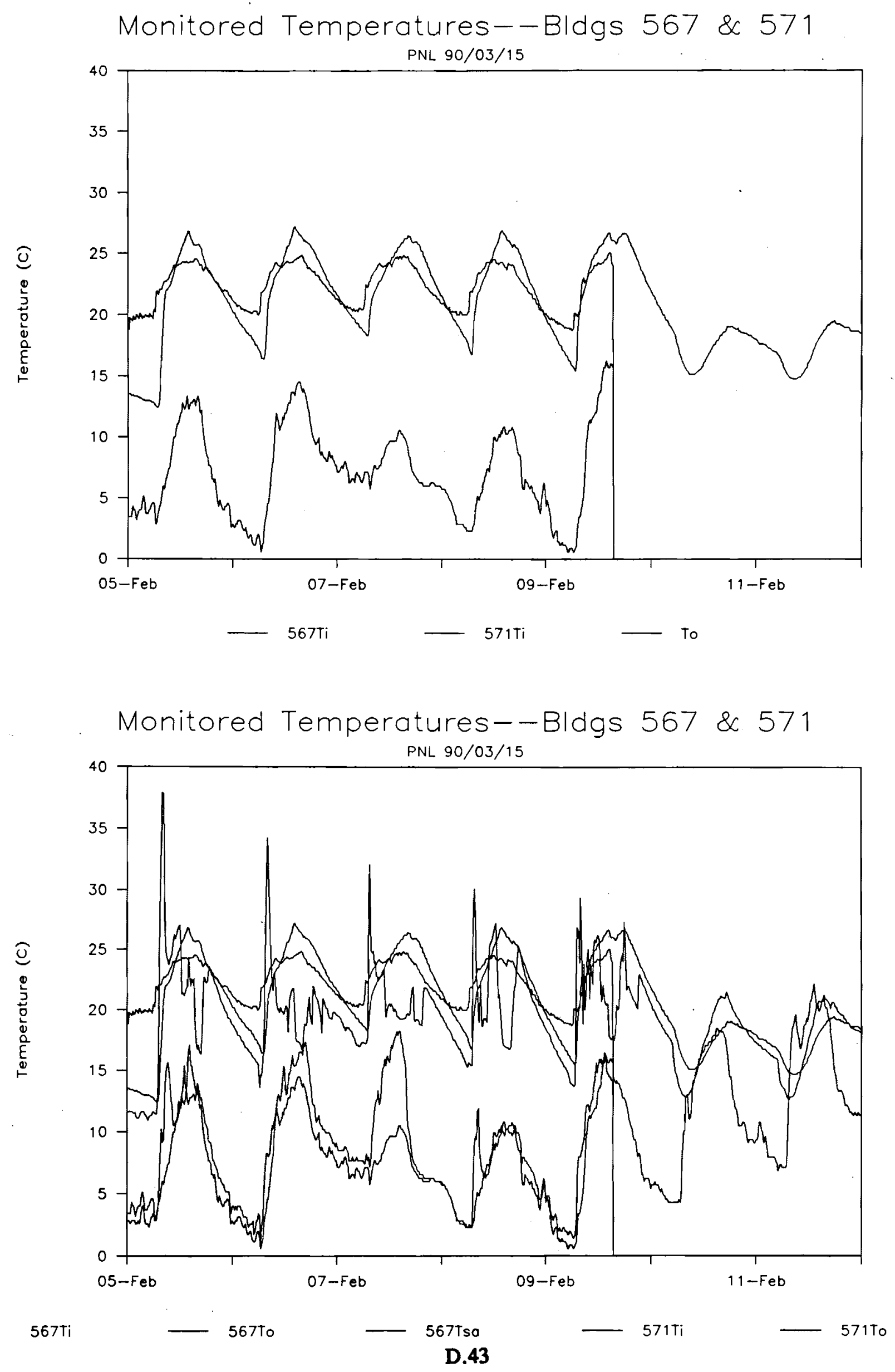


\section{Smoothed Daily Fold--WeekDays}

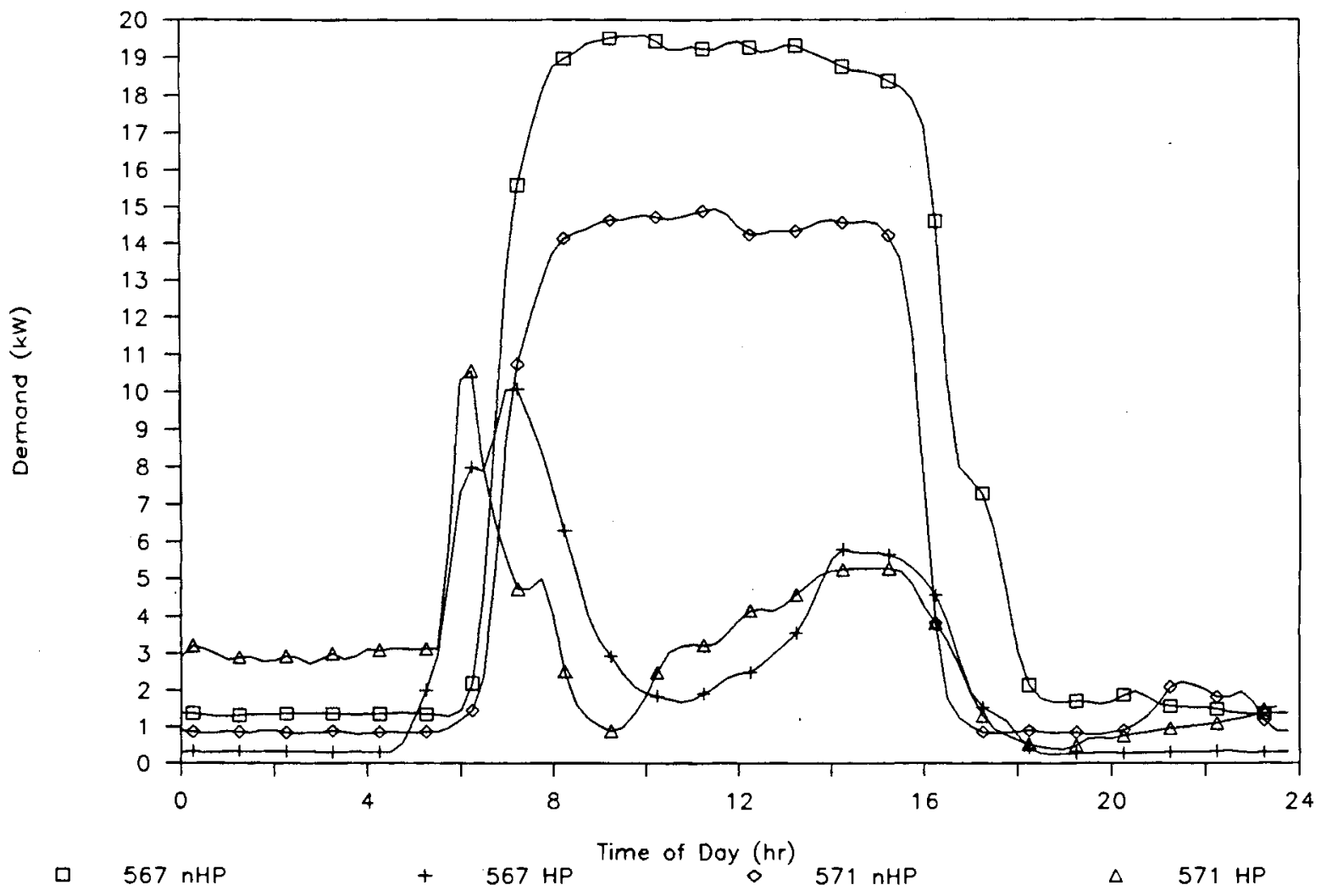

Smoothed Daily Fold--Weekend Days

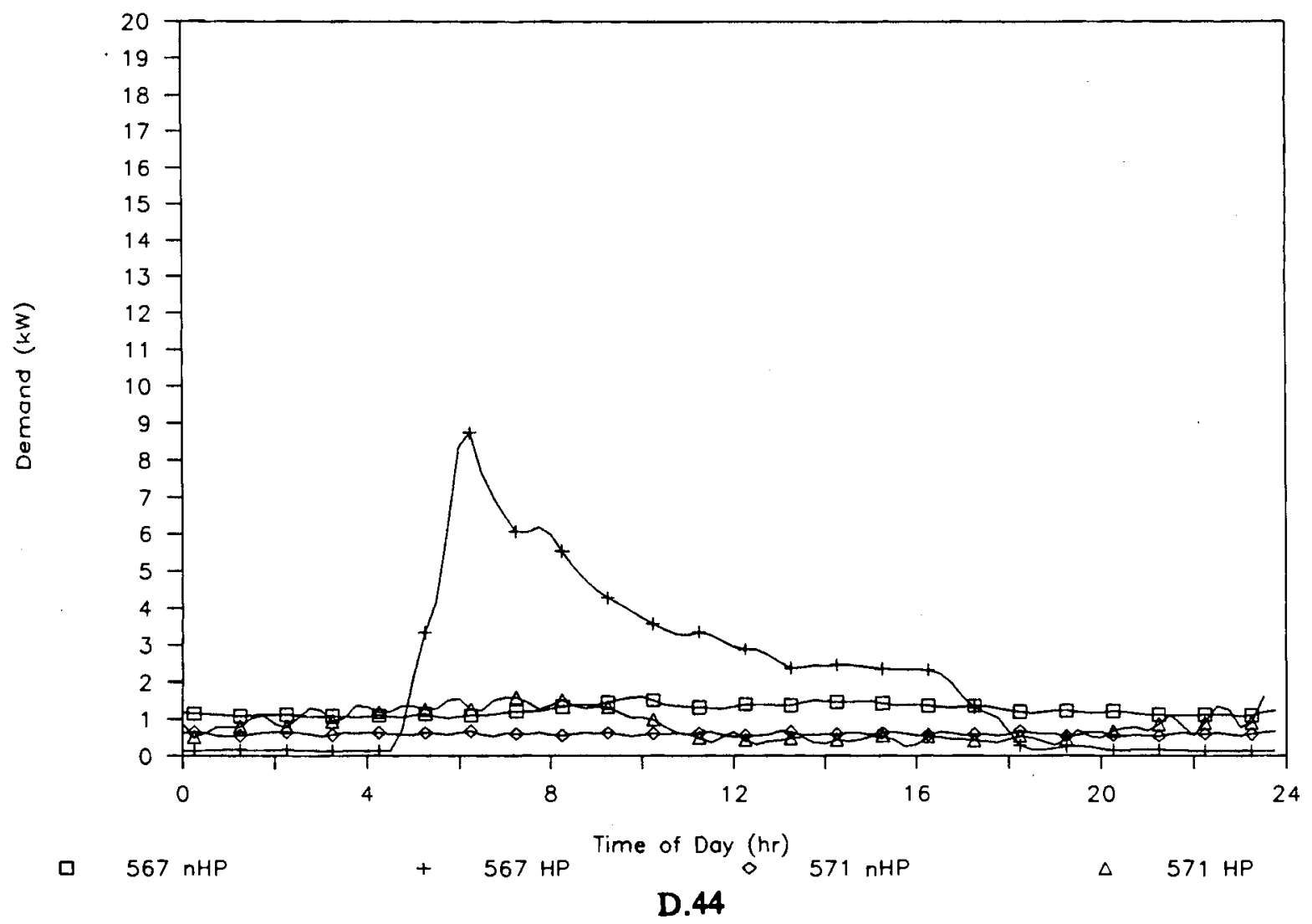




\section{Distribution}

No. of

Copies

\section{QFFSITE}

12 DOE/Office of Scientific and Technical Information

2 A. Gillespie

FORSCOM

Building 200

Fort McPherson, GA 30330-6000

ATTN: FCEN-RDF

2 K. Dean Devine

Federal Energy Management

Program

U.S. Department of Energy

EE-44

1000 Independence Avenue, SW

Washington, DC 20585

M. Ginsberg

Federal Energy Management

Program

U.S. Department of Energy

EE-44

1000 Independence Avenue, SW

Washington, DC 20585

L. Harris

Federal Energy Management

Program

U.S. Department of Energy

EE-44

1000 Independence Avenue, SW

Washington, DC 20585

V. Petrolati

DOE/In-House Energy Management

Branch, FM-33

U.S. Department of Energy

1000 Independence Avenue, SW

Washington, DC 20585
No. of

Copies

Rene Qinones, Energy Manager

Fort Irwin, CA 92310-5000

ATTN: AFZJ-DPW

2 B. H. Starling

U.S. Army Corps of Engineers

Energy Division

P.O. Box 1600

Huntsville AL 35807-4301

ATTN: CEHND-PM-CR

F. Holcomb

U.S. Corps of Engineers

Construction Engineering

Research Laboratory

P.O. Box 4005

Champaign, IL 61820-1305

C. E. Hancock

815 Alpine, Suite 6

Boulder, CO 80304

R. Judkoff

NREL

1617 Cole Boulevard

Golden, CO 8041

\section{ONSITE}

DOE Richland Operations Office

D. D. Green

36 Pacific Northwest Laboratory

P. R. Armstrong, K5-08 (4)

D. M. Carroll, K5-08

F. V. Di Massa, K8-18

J. A. Dirks, K8-18

A. L. Dittmer, K8-08

D. R. Dixon, K8-17 (2) 
No. of

Copies

D. L. Hadley, K5-08 (4)

M. A. Halverson, K5-08

J. M. Keller, K5-08

K. L. McMordie, K5-08
No. of

Copies

G. B. Parker, K8-54 (4)

S. A. Parker, K5-08

D. R. Payson, K7-90

E. E. Richman, K5-08

W. F. Sandusky, K5-08

R. F. Szydlowski, K5-08

R. R. Wahlstrom, K5-08

D. W. Winiarski, K5-08

Project File (2)

Publishing Coordination

Technical Report Files (5) 